UNIVERSIDADE DE SÃO PAULO

FACULDADE DE MEDICINA DE RIBEIRÃO PRETO

PÓS-GRADUAÇÃO EM IMUNLOGIA BÁSICA E APLICADA

\title{
Papel de linfócitos Th17 durante a infecção experimental por Leishmania infantum/chagasi
}

Manuela Sales Lima Nascimento

Ribeirão Preto - SP 
Papel de linfócitos Th17 durante a infecção experimental por

Leishmania infantum/chagasi

Dissertação apresentada ao curso de Pósgraduação em Imunologia Básica e Aplicada da Faculdade de Medicina de Ribeirão Preto da Universidade de São Paulo, para obtenção do grau de Mestre em Ciências - Área de concentração: Imunologia Básica e Aplicada

Orientação: Prof. Dr. João Santana da Silva

Ribeirão Preto - SP 


\author{
AUTORIZO A REPRODUÇÃO E DIVULGAÇÃO TOTAL OU PARCIAL \\ DESTE TRABALHO, POR QUALQUER MEIO CONVENCIONAL OU \\ ELETRÔNICO, PARA FINS DE ESTUDO E PESQUISA, DESDE QUE CITADA
}

A FONTE.

\title{
FICHA CATALOGRÁFICA
}

Nascimento, Manuela Sales Lima

Papel de linfócitos Th17 durante a infecção experimental por Leishmania infantum/chagasi.

Ribeirão Preto, 2012. 119p.; Il.; 30 cm.

Dissertação de Mestrado, apresentada à Faculdade de Medicina de Ribeirão Preto/USP. Área de Concentração: Imunologia Básica e Aplicada.

Orientador: Silva, João Santana.

1. Leishımania infantum//chagasi. 2. Leishmaniose visceral. 3. Células Th17 
Trabalho realizado no Laboratório de Imunoparasitologia, Departamento de Bioquímica e Imunologia da Faculdade de Medicina de Ribeirão Preto da Universidade de São Paulo, com auxílio Financeiro da Capes/INCTV, CNPQ e FAPESP, processo No 2010/14170-7. 


\title{
MANUELA SALES LIMA NASCIMENTO
}

\section{Papel de linfócitos Th17 durante a infecção experimental por Leishmania infantum/chagasi}

\author{
Dissertação apresentada ao curso de Pós- \\ graduação em Imunologia Básica e Aplicada da \\ Faculdade de Medicina de Ribeirão Preto da \\ Universidade de São Paulo, para obtenção do \\ grau de Mestre em Ciências - Área de \\ concentração: Imunologia Básica e Aplicada
}

Aprovada em:

Banca Examinadora

Prof. Dr. João Santana da Silva

FMRP - USP

Prof. (a). Dr. José Carlos Alves Filho

FMRP - USP

Prof. (a) Dr. Roque Pacheco

UFS 
Dedico esse trabalho aos meus pais, pelo apoio incansável que me ofertam. Toda a conquista é para vocês. 


\section{AGRADECIMENTOS}

Aos meus pais, Regina e Goiamir, pelo apoio e incentivo constante, incansável e ilimitado aos meus estudos. Por acreditarem em mim e lutarem comigo para realização de mais um sonho;

Ao meu namorado, Paulo, por sempre permanecer "ao meu lado", nunca duvidar da minha capacidade e pelo apoio imensurável durante todo tempo;

Ao Big-boss, Prof. João Santana, pelos ensinamentos, confiança e amizade devotados. Obrigada pela oportunidade e pelo exemplo de amor a pesquisa que o senhor transparece aos alunos, será sempre o meu exemplo. E também à sua esposa, Maria Fernanda, pela amizade e demonstrações sinceras de carinho.

Aos professores que compõem a banca, Dr. José Carlos e Dr. Roque Pacheco, pela disponibilidade concedida;

Ao Prof. Dr. Marcos Rossi, suas técnicas de laboratório Maria Elena e Mônica e à doutoranda Cibele pela disponibilidade e valioso auxílio;

A Ana Cristine que sempre me auxiliou com muito carinho e eficácia durante toda a minha jornada de mestranda;

Ao grupo da Leishmania, Diego, Djalma, Khalid e em especial Vanessa e Laís, pelo apoio, ensinamentos e espírito de equipe. Vocês me ajudaram muito a crescer cientificamente; 
Aos amigos Elen, Patrícia, Francielle, Laís, Grace, Maria Cláudia, Gustavo, Luís Gustavo, Raphael e Tiago, vocês contribuíram significativamente para minha formação pessoal e profissional.

A todos os demais que compõem o laboratório de Imunoparasitologia, técnicos, bioteristas, alunos de iniciação científica, mestrandos, doutorandos, pos-docs e agregados, em especial Fernanda, Marcela Davoli, Marcela Fransoso, Maria do Carmo, Denise, Giuliano, Renata, Luciana e Cristiane, vocês foram essenciais para mim durante esse trajeto;

A FAPESP, CAPES/INCT, CNPq e FAEPA pelo incentivo financeiro;

O meu muito obrigada! 
"O cientista é o elemento essencial à Ciência, e além de um ser humano dotado de um cérebro imaginativo, possui sentimentos, emoções..."

Autor desconhecido

"Agradeço todas as dificuldades que enfrentei; não fosse por elas, eu não teria saído do lugar. As facilidades nos impedem de caminhar..." Chico Chavier 


\section{Sumário}

LISTA DE FIGURAS...............................................................................

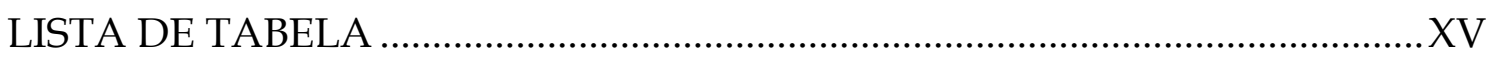

LISTA DE ABREVIATURAS..............................................................................

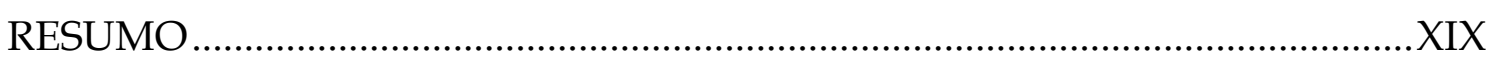

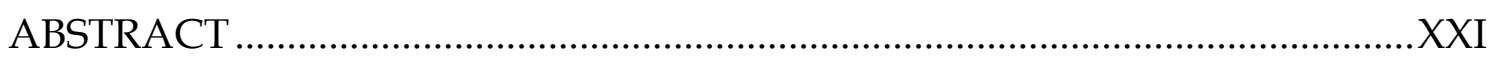

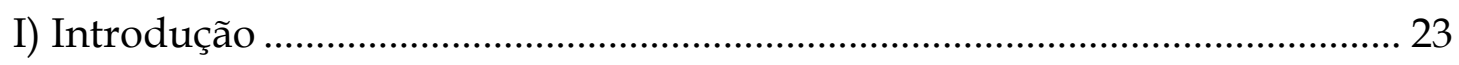

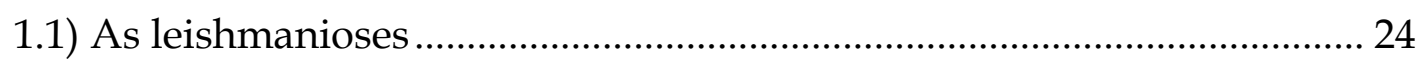

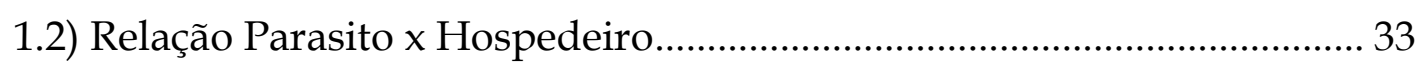

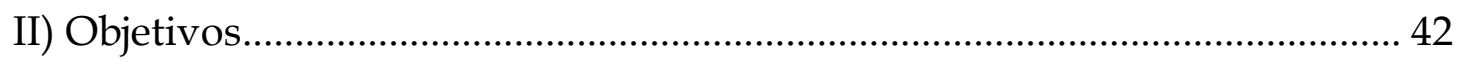

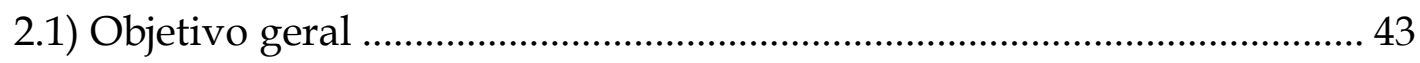

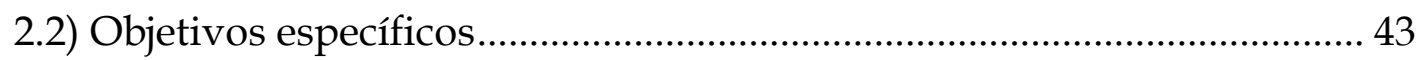

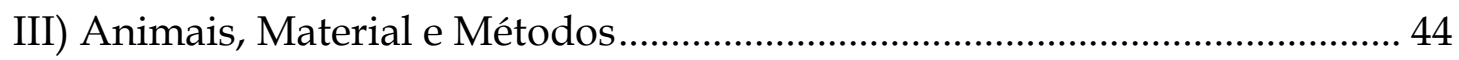

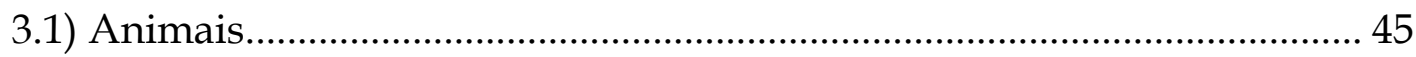

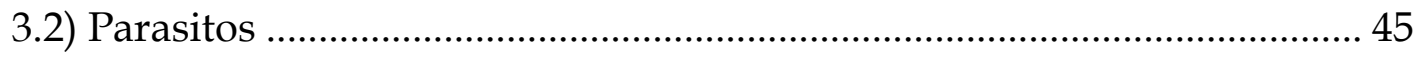


3.3) Diferenciação de Células Dendríticas (BMDC) e Macrófagos (BMMФ) a Partir de Células Precursoras da Medula Óssea ................................................... 46

3.4) Infecção de Células in vitro ....................................................................... 47

3.5) Separação de Células do Baço e Ensaio de Co-cultura............................... 48

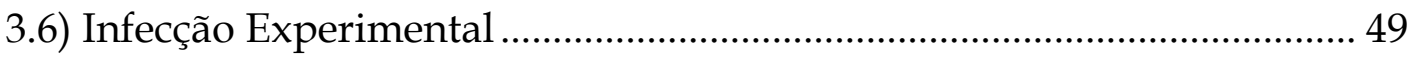

3.7) Análise da Carga Parasitária dos Animais................................................... 49

3.8) Antígeno Particulado de L. infantum/chagasi, Cultura de Células do Baço e Fígado

3.9) Dosagem de Citocinas por ELISA ………………………………………... 51

3.10) Determinação do Padrão de Citocinas por Citometria de Fluxo .......... 52

3.11) Extração de RNA total e confecção do DNA complementar (cDNA). 53

3.12) PCR em Tempo Real .......................................................................... 55

3.13) Análise Histopatológica do Fígado ……………………………………..... 56

3.14) Ensaio de Proliferação por Diluição de CFSE ............................................. 57

3.15) Obtenção do Soro e Dosagem Bioquímica de Transaminase Glutâmico-Oxalacética....................................................................................... 58 
3.16) Avaliação da Produção de Óxido Nítrico por Macrófagos Infectados 58

3.17) Imunofluorescência

3.18) Análise Estatística 60

IV) Resultados 62

4.1) A infecção por L. infantum/chagasi dirige a resposta imune adaptativa para o perfil Th17

4.2) Células Th17 desempenham papel crítico no controle da infecção por $L$. infantum/chagasi 67

4.3) A citocina IL-17 é fundamental para o processo inflamatório hepático durante a infecção por L. infantum/chagasi.....

4.4) IL-10 regula negativamente os níveis de IL-17 induzidos pela $L$. infantum/chagasi...... 78

4.5) IL-17 tem papel importante para promover aumento da secreção de óxido nítrico durante a infecção por L. infantum/chagasi 81

V) Discussão 89

VI) Conclusão 101

VII) Referências Bibliográficas 103 


\section{LISTA DE FIGURAS}

Figura 1: Ciclo de vida assexuado dos parasitos do gênero Leishmania

Figura 2: Distribuição mundial de leishmaniose visceral no mundo 31

Figura 3: Polarização dos linfócitos T. 39

Figura 4: L. infantum/chagasi induz a liberação dos fatores necessários para polarização dos linfócitos para o padrão Th17. 64

Figura 5: L. infantum/chagasi polariza linfócitos de camundongos C57BL/6 naïve para o perfil Th17. 66

Figura 6: L. infantum/chagasi induz a produção de IL-17 in vivo nos órgãos alvo da inflamação 68

Figura 7: Os linfócitos Th17 participam no controle da infecção por $L$. infantum/chagasi. .70

Figura 8: A citocina IL-17 contribui para o processo inflamatório hepático induzido por L. infantum/chagasi 73

Figura 9: A citocina IL-17 é importante para manutenção da capacidade proliferativa de linfócitos e consequente crescimento dos órgãos afetados pelo parasito .76 
Figura 10: A citocina IL-17 regula negativamente a produção de IL-10 por

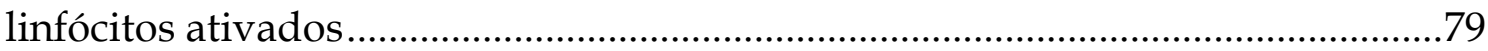

Figura 11: : IL-10 regula negativamente a produção de IL-17

Figura 12: Efeito sinérgico da IL-17 e do IFN-ץ na potencialização da secreção de NO por macrófagos infectados 84

Figura 13: A citocina IL-17 é essencial para a manutenção da expressão de iNOS durante a infecção. . .86 


\section{LISTA DE TABELA}

Tabela I: Sequência dos primers utilizados nas reações de PCR em tempo real. 56 


\section{LISTA DE ABREVIATURAS}

Ag - Antígeno

APC - Célula apresentadora de antígeno

AP1 - Activator protein 1

BMDC - Células dendríticas derivadas de precursores da medula óssea

BMMФ - Macrófagos derivados de precursores da medula óssea

BSA - Albumina sérica bovina

CD - Cluster de diferenciação

cDNA - DNA complementar

CFSE - Carboxifluoresceína succinimidil ester (Carboxyfluorescein succinimidyl Ester)

$\mathrm{CO}_{2}$ - Dióxido de carbono

Ct - Linha de corte (cicle threshold)

DTH - Hipersensibilidade do tipo tardia

DP - Desvio padrão

eNOS - Óxido nítrico sintase endotelial

FoxP3 - Forkhead Box P3

GM-CSF - Fator estimulador de colônias de macrófagos e granulócitos

h - Horas

HIV - Vírus da Imunodeficiência Humana 
H\&E - Hematoxilina e Eosina

HPRT - Hipoxantina-guanina fosforibosiltransferase (Hypoxanthine-guanine phosphoribosyltransferase)

HU-UFS - Hospital Universitário da Universidade Federal de Sergipe

IFN- $\gamma$ - Interferon-gama

IL - Interleucina

IL-17R - Receptor da interleucina 17

IL-10\%-- - Deleção homozigótica do gene para IL-10

IL-17R-/- - Deleção homozigótica do gene para IL-17R

IL-22/- - Deleção homozigótica do gene para IL-22

IL-23p19-/- - Deleção homozigótica do gene para IL-23p19

IL-6//- - Deleção homozigótica do gene para IL-6

iNOS/NOS2 - Óxido nítrico sintase induzível

iv - intravenoso

LC - Leishmaniose cutânea

LCD - Leishmaniose cutânea difusa

LDPC - Leishmaniose dérmica pós-calazar

LV - Leishmaniose visceral

LM - Leishmaniose mucocutânea

mRNA - RNA mensageiro

NF- $\mathrm{kB}$ - Fator nuclear $\kappa \mathrm{B}$ 
NI - Não infectado

NO - Óxido nítrico

PBMC - Células mononucleares de sangue periférico

PCR - Reação da polimerase em cadeia

PMA - Phorbol 12-myristate 13-acetate

Sem - Semanas após infecção

TGF- $\beta$ - Fator de transformação de crescimento beta

Th - Célula T auxiliar

TNF - Fator de necrose tumoral

$\mathrm{T}$ regs - Células $\mathrm{T}$ reguladoras

TGO - Transaminase oxalacética

Who - Organização Mundial de Saúde (World Health Organization)

WT - Camundongo do tipo selvagem (wild type) 


\section{RESUMO}

Leishmaniose visceral (LV) é uma doença crônica e potencialmente fatal causada pelas espécies Leishmania infantum/chagasi e Leishmania donovani. O desenvolvimento da resposta Th1 é classicamente associado à proteção contra esses parasitos, mas também há uma correlação positiva entre a produção de citocinas relacionadas com o padrão Th17 e a proteção contra LV por L. donovani em seres humanos. No entanto, a participação de Th17 durante a infecção por L. infantum/chagasi permanece desconhecida. O objetivo desse estudo foi avaliar a participação de Th17 e citocinas relacionadas, além do mecanismo pelo qual tais células operam durante a resposta imune do hospedeiro contra L. infantum/chagasi. Os resultados mostraram que o parasito é capaz de induzir grandes quantidades de TGF- $\beta$, IL-1 $\beta$, IL-6 e IL-23 por células dendríticas derivadas da medula óssea (BMDC), citocinas envolvidas na indução e/ou manutenção do perfil Th17. Assim, co-cultivando células do baço de camundongos C57BL/6 naïves com BMDCs infectadas com $L$. infantum/chagasi observou-se uma significativa produção de IL-17 por células T. Esses achados foram confirmados por experimentos in vivo onde se constatou a produção de IL-17 no fígado e no baço de camundongos WT infectados, sendo o pico de produção dessa citocina observado na $4^{\mathrm{a}}$ e $6^{\mathrm{a}}$ semanas após a infecção. $\mathrm{O}$ padrão de resposta do tipo Th17 é crítica para a imunidade protetora contra $L$. 
infantum/chagasi, uma vez que camudongos IL-17R-/, IL-23p19-/- e IL-6/mostraram aumento da carga parasitária nos órgãos alvo da infecção, sendo que a susceptibilidade observada em camundongos IL-17R $\%$ - foi associada com o aumento da produção de IL-10 por linfócitos, sugerindo que a IL-17 regula negativamente a produção de IL-10 levando ao controle da infecção causada pelo parasito. Ainda, a ausência da sinalização via IL-17R gerou uma diminuição da inflamação hepática, decorrente de uma menor capacidade proliferativa de linfócitos frente ao estímulo com conA. De maneira interessante, na ausência de IL-10 houve potencialização na produção de IL-17 por camundongos infectados, e esses foram mais resistentes à infecção, apresentando números reduzidos parasitos no baço e no fígado. Além de promover proteção através da modulação de IL-10, a IL-17 foi capaz de potencializar a produção de $\mathrm{NO}$ in vitro e in vivo. Juntos, nossos resultados demonstram que a L. infantum/chagasi é capaz de desencadear o padrão Th17 de resposta imune, o qual promove proteção do hospedeiro durante a infecção.

Palavras-chaves: Leishmania infantum/chagasi, leishmaniose visceral, linfócitos Th17 


\begin{abstract}
Visceral leishmaniasis (LV) is a chronic and potentially fatal disease caused by Leishmania donovani and Leishmania infantum/chagasi. The development of Th1 response is classically associated with protection against these parasites, but recent data also show that there is a positive correlation between the Th17related cytokines production and the protection against LV by L. donovani in humans. However, the role of this $\mathrm{CD} 4^{+} \mathrm{T}$ cells subset during L. infantum/chagasi infection remains unknown. In this study, our aim was to evaluate the Th17 and related cytokines participation, besides the mechanism by which these cells playing during the L. infantum/chagasi infection. The results showed that the parasite induces high amounts of TGF- $\beta$, IL-1 $\beta$, IL-6, and IL-23 by bone marrow-derived dendritic cells (BMDC), cytokines involved with Th17 induction and/or maintenance. Accordingly, naïve-C57BL/6 spleenocytes cocultured with $L$. infantum/chagasi-infected BMDC produced significant amounts of IL-17 by TCD4+ Interestingly, IL-17 was produced in high amounts in the liver and spleen of WT infected-mice, being peaked at $4^{\text {th }}$ and $6^{\text {th }}$ weeks after infection. The Th17 is critical for protective immunity against $L$. infantum/chagasi, since that IL-17R-/-, IL-23p19-/- and IL-6/-- infected-mice showed increasing of parasite load associated with enhancement of IL-10 production in IL-17R-/- compared to WT infected-mice. Strictly, in the absence
\end{abstract}


of IL-17 signaling, a smaller inflammatory infiltrate was observed in the liver. Interestingly, IL-17 production was potentiated in IL-10/- infected-mice, and they were more resistant to infection, showing reduced parasites numbers in the spleen and liver. In addition to promoting protection through the downmodulation of IL-10, IL-17 enhanced the NO production. Together, our results demonstrate that L. infantum/chagasi trigger Th17 response that promotes the host protection during infection.

Keywords: Leishmania infantum/chagasi, visceral leishmaniasis, Th17 response. 
I) Introdução 


\section{1) As leishmanioses}

As leishmanioses compreendem um complexo de doenças causadas por parasitos intracelulares obrigatórios pertencentes à ordem Kinetoplastida, à família Tripanossomatidae e ao gênero Leishmania. Este gênero inclui inúmeras espécies de protozoários flagelados unicelulares que são agentes causadores de enfermidades em diversos hospedeiros em ciclos zoonóticos, antropozoonóticos e até mesmo antroponóticos (LAINSON; SHAW; SILVEIRA, 1987; TESH, 1995).

Esse conjunto de doenças constitui uma das mais importantes doenças tropicais negligenciadas do mundo, com 350 milhões de pessoas em 88 países vivendo sob o risco de contrair e desenvolver uma das formas de leishmaniose. A prevalência mundial é de 12 milhões de pessoas infectadas atualmente em todo o mundo, e, aproximadamente, 2 milhões de novos casos surgem por ano (nos quais, aproximadamente, 1-1,5 milhões de casos são de leishmaniose cutânea-LC e 500.000 de leishmaniose visceral-LV), sendo que destes, em $\begin{array}{lllll}\text { média, } & 70.000 & \text { resultam } & \text { em }\end{array}$ http://www.paho.org/english/ad/dpc/cd/res-dch-leish-priorities.pdf). A alta incidência acompanhada muitas vezes de lesões desfigurantes e casos fatais, fez com que a Organização Mundial de Saúde a incluísse entre as seis endemias mais importantes do mundo. 
As manifestações clínicas das leishmanioses estão diretamente relacionadas com a espécie de Leishmania e a resposta imune do hospedeiro, podendo variar desde acometimento de pele e mucosas até a doença visceral. Em se tratando das espécies de Leishmania, elas foram divididas em dois subgêneros distintos, Viannia e Leishmania, de acordo com o ciclo de vida apresentado no interior do inseto vetor. Além disso, os parasitos são separados em quatro complexos fenotípicos segundo características clínicas, epidemiológicas, de desenvolvimento em animais de laboratório (hamsters), em meio de cultura e características genéticas e isoenzimáticas, são eles: complexo Leishmania braziliensis, Leishmania mexicana, Leishmania tropica e Leishmania donovani. Os parasitos pertencentes ao complexo Leishmania braziliensis ( $L$. braziliensis, L.panamensis, L. guyanensis, e L. peruviana) são encontrados apenas nas Américas (novo mundo) e caracterizam-se pelo parasitismo cutâneo (LC) e/ou mucocutâneo (leishmaniose mucocutânea- LM) sem invasão de vísceras. A LC surge como úlceras na pele no local da picada, podendo evoluir e disseminar-se ou não, enquanto que a LM é uma consequência da LC, que pode surgir mesmo anos após a cicatrização da primeira úlcera da pele, resultando em uma progressiva ulceração na mucosa nasal e/ ou junções mucocutâneas. $O$ complexo Leishmania mexicana inclui as espécies L. mexicana, L.pifanoi e L. amazonensis, essas geram lesões que não atingem a região mucosa, porém podem causar uma forma rara e complicada da LC, chamada de leishmaniose 
cutânea difusa (LCD) a qual ocorre como consequência de uma deficiência na resposta imune mediada por células, onde os nódulos cutâneos disseminam-se por toda a região corpórea. Nos países do velho mundo, principalmente na região da Bacia do Mediterrâneo e na Ásia, o complexo Leishmania tropica, o qual inclui as espécies L. tropica, L. major e L. aethiopica, causam lesões restritas à pele (EL-HASSAN et al., 1995; REITHINGER et al., 2007; WILSON; JERONIMO; PEARSON, 2005).

A forma mais grave das leishmanioses é a leishmaniose visceral (LV), uma doença sistêmica, crônica e potencialmente fatal, que, quando não tratada, a taxa de letalidade em países em desenvolvimento pode ser de $100 \%$ em 2 anos (WHO 2011 http://www.who.int/leishmaniasis/ visceral_leishmaniasis/en/ index.html). Essa doença caracteriza-se pela disseminação dos parasitos para as vísceras (principalmente baço e fígado) e também para a medula óssea. As formas clínicas são diversas, podendo o indivíduo apresentar desde cura espontânea, formas oligo e assintomáticas, até manifestações graves, que podem levar ao óbito (WILSON; STREIT, 1996). Os indivíduos que desenvolvem a doença apresentam sintomas como febre prolongada, perda de peso, hepatoesplenomegalia, pancitopenia, hipergamaglobulinemia, linfoadenopatia e anemia. As espécies do complexo Leishmania donovani são as responsáveis pela LV, e compreendem a L. donovani, L. infantum e L. chagasi. Hoje é consenso considerar L. infantum e L. chagasi como uma única espécie 
(MAURICIO; STOTHARD; MILES, 2000; MOMEN et al., 1993), referidas nesse trabalho como L. infantum/chagasi. Esta espécie é o agente etiológico da LV no Brasil e em outros países do novo mundo (MAURICIO; STOTHARD; MILES, 2000), enquanto que a L. donovani causa LV em países do velho mundo (WILSON; JERONIMO; PEARSON, 2005). Após o tratamento da LV, alguns pacientes desenvolvem leishmaniose dérmica pós-calazar (LDPC), a qual se caracteriza pelo aparecimento de lesões cutâneas. A LDPC ocorre em consequência da LV causada por L. donovani (RAMESH, 1993; ZIJLSTRA; ELHASSAN, 2001).

As Leishmanias podem se apresentar sob duas formas morfológicas distintas, variando de acordo com o hospedeiro. A forma promastigota é alongada, apresenta cinetoplasto anterior ao núcleo e um flagelo livre em uma porção da célula; enquanto que a amastigota possui forma oval ou esférica com flagelo interiorizado. O seu ciclo de transmissão é dependente de insetos vetores (KILLICK-KENDRICK, 1990a), os flebotomíneos, pertencentes aos gêneros Phlebotomus (transmissor em países do velho mundo) e Lutzomyia (no novo mundo). As fêmeas do flebótomo são hematófagas e, na ocasião do repasto sanguíneo em animais infectados, formas amastigotas que habitam o interior dos macrófagos e monócitos hospedeiros são ingeridas juntamente com o sangue. No interior do trato digestivo do inseto, a forma oval sofre modificações para a forma promastigota (procíclica) extracelular, que se 
multiplica por divisão binária e se aderem às paredes do intestino do inseto. Posteriormente, os parasitos migram para as glândulas salivares do inseto, sofrem divisão binária novamente e findam por se diferenciarem em uma forma móvel, mas indivisível, as promastigotas metacíclicas (KILLICK-KENDRICK, 1990b; SACKS; PERKINS, 1985). A grande multiplicação de parasitos no interior do trato digestivo dificulta a ingestão e a digestão do alimento pelas fêmeas, tornando o repasto um ato de grande esforço. Nessa situação, após cada tentativa de ingerir sangue, os músculos encarregados da sucção relaxam e causam regurgitação do material aspirado juntamente com os parasitos e componentes salivares, e assim, durante o próximo repasto ocorre a inoculação das formas metacíclicas infectantes em novos hospedeiros (SACKS; KAMHAWI, 2001), garantindo a transmissão e perpetuando o ciclo da Leishmania (Figura 1). Além dessa teoria clonal, que se baseia no conceito de que a prole de parasitos é geneticamente idêntica aos seus progenitores, divisões sexuais nos parasitos do gênero Leishmania já são relatadas (KREUTZER et al., 1994). Os novos trabalhos tem identificado cepas de Leishmania que compartilham marcadores genéticos de duas espécies conhecidas, fornecendo evidências circunstanciais para a reprodução sexual. Esse tipo de reprodução parece ocorrer somente no aparelho digestivo dos insetos vetores, e essa descoberta surge como uma implicação importante visto que uma progênie híbrida com possíveis recombinações gênicas pode surgir, gerar seleção de 
parasitos cada vez mais virulentos e que podem ser transmitidos para o hospedeiro vertebrado (AKOPYANTS et al., 2009; ROUGERON et al., 2010; ROUGERON et al., 2009).

Dentre os hospedeiros vertebrados em potencial, inclui-se uma grande variedade de mamíferos, sendo os mais comuns os roedores e os canídeos, mas também podem aparecer os edentados, marsupiais, procionídeos, ungulados e primatas, incluindo o homem (NEAL; REEVES; PETERS, 1990; PETERS et al., 1990).

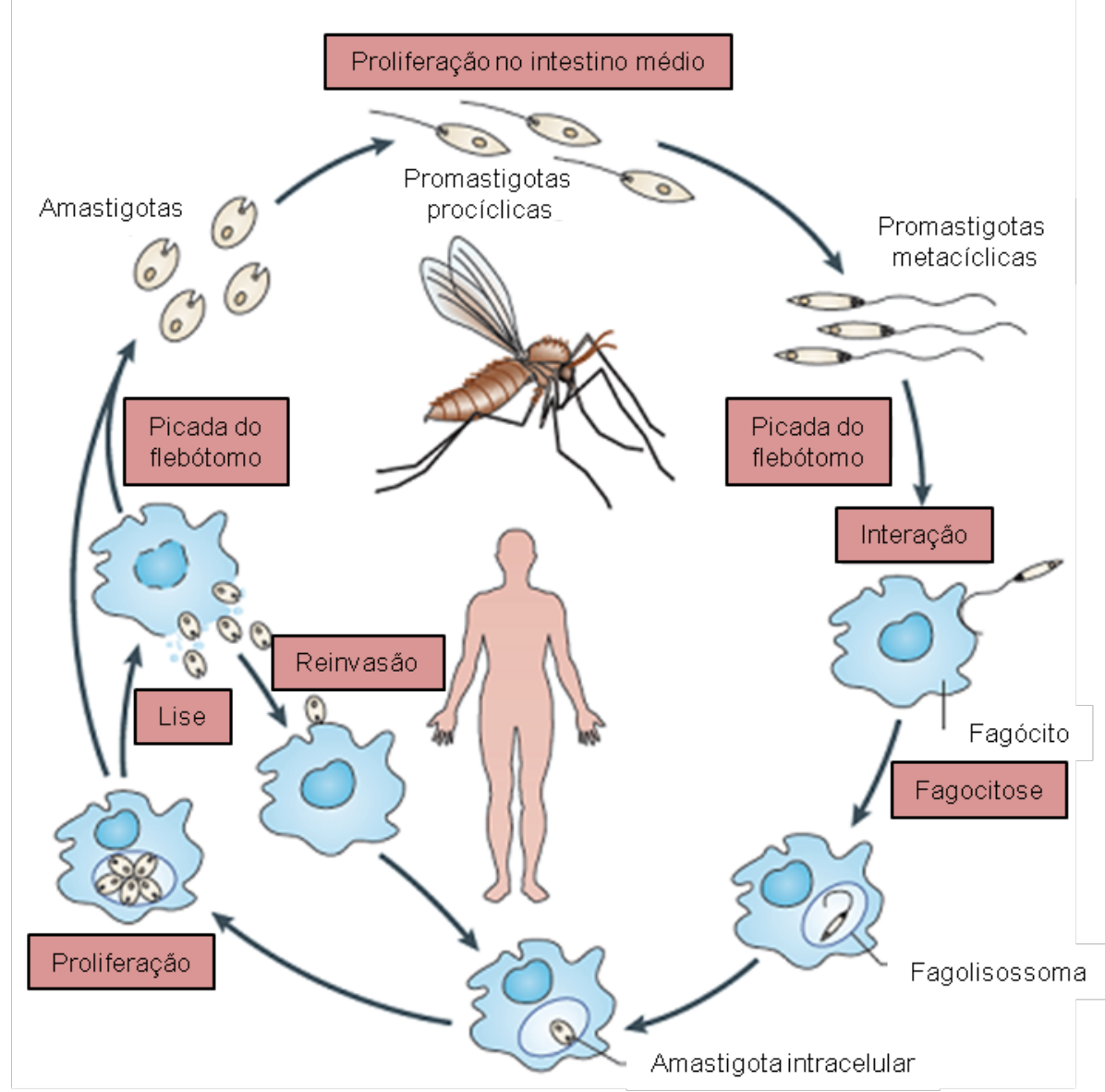

Figura 1: Ciclo de vida assexuado dos parasitos do gênero Leishmania. Retirado e adaptado de KAYE; SCOTT, 2011. 
Sendo uma doença vetorial, a distribuição do flebotomíneo influencia diretamente a distribuição geográfica dos casos de leishmaniose. Essas doenças ocorrem em mais de 100 países de clima tropical e subtropical, abrangendo o sul da Europa, norte da África, Oriente Médio, América Central e América do Sul, que são consideradas áreas endêmicas, e também sudeste da Ásia e a Austrália que são áreas não endêmicas (ASHFORD, 2000; HERWALDT, 1999) (Figura 2). A LV é endêmica em 65 países com um total estimado de 350 milhões de pessoas sob risco de contrair a infecção, sendo 90\% dos casos concentrados na Índia, Bangladesh, Nepal, Sudão e Brasil (DESJEUX, 2004).

A LV humana apresenta-se amplamente distribuída por toda a América Latina. A doença era tipicamente silvestre, mantinha um perfil rural de transmissão peridomiciliar, mas vem se urbanizando e hoje se encontra em franca expansão, com aumento significativo de áreas endêmicas, além do surgimento de no vos focos. Essa modificação no cenário epidemiológico pode ser associada a modificações ambientais, destruição de habitats, desmatamento, migrações de populações carentes para periferia de grandes centros fixando-se em locais sem infraestrutura de saneamento básico e em promiscuidade com animais domésticos; somado com a adaptação do inseto vetor aos ambientes alterados pelo homem. Esses fatores contribuem para os dados preocupantes sobre infecção, doença e mortalidade em humanos que esta enfermidade tem causado (JERONIMO et al., 2004). 


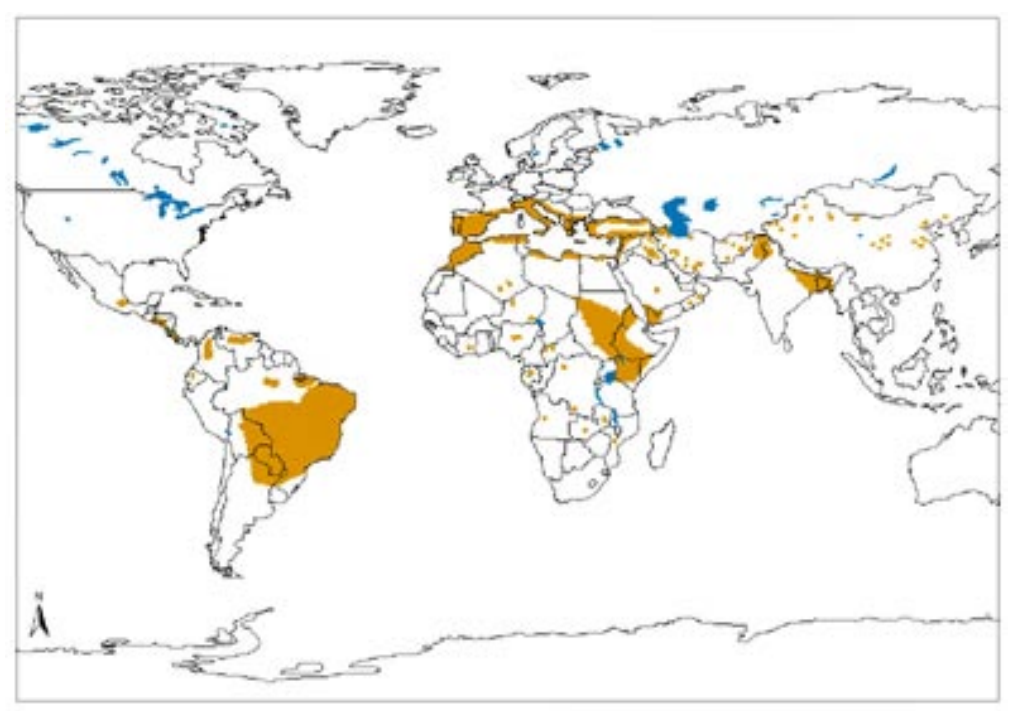

Figura 2: Distribuição mundial de leishmaniose visceral no mundo (WHO, 2012 http://www.who.int/leishmaniasis/leishmaniasis_maps/en/index.html)

A incidência da doença nas áreas endêmicas apresenta um perfil cíclico, com surtos de 7 a 10 anos (JERONIMO et al., 2004). Temperatura, umidade, velocidade do vento e chuvas são fatores que parecem estar relacionados com essa periodicidade, pois, provavelmente, reflete a resposta do vetor às alterações ambientais (FRANKE et al., 2002; XIMENES et al., 2006).

As mudanças nos padrões de distribuição das leishmanioses (incidência em áreas periurbanas e urbanas) somadas ao surgimento da epidemia do vírus da imunodeficiência humana (HIV), o qual possui prevalência em áreas urbanas, tem favorecido o aparecimento de co-infecções Leishmania-HIV, além do crescimento do número de casos de leishmanioses devido a 
imunossupressão oriunda da co-infecção. São crescentes os registros de casos da co-infecção no sudeste da Europa; distribuído em Portugal, França, Itália e Espanha; nas Américas, mais expressivamente no Brasil, onde a incidência de indivíduos HIV positivos tem aumentado significantemente de 0,8 casos/100.000 habitantes em 1986 para 10,5 casos/ 100.000 habitantes em 1997 (ALVAR et al., 1997). Um fato relevante nessa situação é que, na presença do HIV, a L. infantum/chagasi já circulante no ambiente peridoméstico pode desenvolver seu ciclo sem a intervenção de outro hospedeiro vertebrado, à exceção dos seres humanos, enquadrando epidemiologicamente a LV como uma antroponose (TESH, 1995). Além disso, mesmo em casos de HIV negativo, já se observa uma manifestação antroponótica da LV causada por L. donovani na Índia (THEODOR, 1964).

As condições atuais da doença a enquadram como um sério problema de saúde pública, e a expansão e urbanização ocorridas nos últimos 30 anos colocam em pauta discussões sobre as estratégias de controle empregadas. A ocorrência da doença em uma determinada área depende, basicamente, da presença do vetor susceptível e de um hospedeiro/reservatório igualmente susceptível. O diagnóstico precoce atrelado ao tratamento eficiente compõe formas eficazes de controlar o desenvolvimento da doença no indivíduo e na população, sendo esses dois quesitos dependentes de estudos sobre a resposta imune desenvolvida contra o parasito. 


\section{2) Relação Parasito $x$ Hospedeiro}

Como mencionado anteriormente, durante a picada do flebótomo infectado no hospedeiro vertebrado ocorre a inoculação de Leishmanias infectivas juntamente com componentes salivares. A partir desse momento são acionados mecanismos de resposta imune inata no local da picada e a rede de citocinas produzidas irá manter o elo entre as respostas imunes inata e adaptativa. Esse é o ponto de partida da relação estabelecida entre o parasito e o hospedeiro parasitado, a qual será determinada por fatores complexos como os componentes da saliva do inseto vetor, as proteínas de superfície e secretadas do parasito, além dos diferentes perfis de resposta imunológica que podem ser desencadeadas no hospedeiro. Nesse contexto, respostas de padrões distintos e ainda pouco conhecidos podem ser geradas, desde a cura espontânea dos sintomas, formas oligo e assintomáticas, e até manifestações graves que caracterizam a doença ativa.

De maneira geral, a imunidade protetora na LV está relacionada com a resposta imune celular. Basicamente, monócitos, células dendríticas e macrófagos são responsáveis em capturar o parasito no sítio de inoculação e estimular células $\mathrm{T} \mathrm{CD}^{+}$naïves a se diferenciarem e se proliferarem. A incapacidade de ativar macrófagos para destruir a Leishmania parece ser o

principal defeito nessa doença, o que se associa com a multiplicação e 
disseminação do parasito e acometimento de múltiplos órgãos (CARVALHO et al., 1988; YURDAKUL, 2005).

Os mecanismos imunológicos que conferem resistência ou suscetibilidade à infecção por parasitos do gênero Leishmania foram bem caracterizados em modelos experimentais de infecção com L. major. Uma eficiente apresentação antigênica com os co-estímulos necessários e produção de IL-12 por células dendríticas que fagocitaram os parasitos no sítio de inoculação levam à diferenciação de linfócitos $\mathrm{T}$ naïves em linfócitos Th1 produtores de IFN-ץ (ALEXANDER; BRYSON, 2005; BOGDAN et al., 1996). Juntamente com linfócitos $\mathrm{T} \mathrm{CD}^{+}$, as células $\mathrm{NK}$ e as $\mathrm{T} \mathrm{CD}^{+}$também são fontes importantes de INF-ץ (AWASTHI; MATHUR; SAHA, 2004; BELKAID et al., 2002b; BIRON; GAZZINELLI, 1995; SCHARTON-KERSTEN et al., 1995). Esta citocina atua nos macrófagos, ativando a enzima óxido nítrico sintase induzida (iNOS ou NOS2), com concomitante produção de óxido nítrico (NO), que leva à morte dos parasitos fagocitados. A citocina TNF é produzida por macrófagos e age em sinergismo com IFN-ץ aumentando a ativação de iNOS e assim levando a morte mediada por óxido nítrico (BOGDAN; ROLLINGHOFF; DIEFENBACH, 2000; LIEW et al., 1990; LIEW; WEI; PROUDFOOT, 1997). Em contrapartida, o desenvolvimento de uma resposta imune de padrão Th2 durante a infecção por L. major, caracterizada pelos altos níveis de IL-4 e redução de IL-12, confere suscetibilidade à infecção (SACKS; NOBEN- 
TRAUTH, 2002). Isso pode ser demonstrado por experimentos em que a supressão da resposta Th2 com anticorpo monoclonal anti-IL-4 ou a utilização de animais deficientes para a citocina IL-4 torna camundongos suscetíveis em resistentes (KOPF et al., 1996; SADICK et al., 1990), enquanto que o tratamento com anticorpo monoclonal anti-IFN- $\gamma$ ou a utilização de camundongos knockouts para IFN-ץ (BELOSEVIC et al., 1989) ou para IL-12 (SYPEK et al., 1993) torna camundongos resistentes em suscetíveis. Citocinas como IL-13 e IL10 também estão relacionadas com o padrão de suscetibilidade nesse modelo. (MOHRS et al., 1999; BELKAID et al., 2001b; KANE; MOSSER, 2001; MURRAY et al., 2002; NOBEN-TRAUTH et al., 2003; PADIGEL; ALEXANDER; FARRELL, 2003; YAMAKAMI et al., 2002). Esse mesmo padrão parece ocorrer em humanos infectados com L. major.

$\mathrm{Na} \mathrm{LV}$, a resposta Th1 também está associada com resistência à doença e com a morte dos parasitos, uma vez que animais resistentes à infecção experimental por L. donovani produzem grande quantidade de IFN- $\gamma$ na fase inicial da infecção e são capazes de manter essa produção alta em fases mais tardias. In vitro, foi visto que a ativação de macrófagos com IFN-ץ ou TNF leva à morte de parasitos da espécie L. donovani (MURRAY; RUBIN; ROTHERMEL, 1983; PEARSON; STEIGBIGEL, 1981). Em pacientes assintomáticos são encontradas forte resposta DTH e produção de IL-2, IL-12 e IFN-ץ por células mononucleares de sangue periférico (PBMC) (CARVALHO et al., 1985; 
CARVALHO et al., 1989; CARVALHO et al., 1992). Por outro lado, a ausência de DTH, a redução da capacidade de linfoproliferação e de produção de IL-2 e IFN-ץ por PBMC em resposta ao antígeno do parasito são encontradas em pessoas que desenvolvem LV por L. infantum/chagasi ou L. donovani, além da presença de níveis elevados de IL-10 (CARVALHO et al., 1985; SACKS et al., 1987). Curiosamente, as células T de indivíduos que evoluem para LV não estão totalmente suprimidas, pois apesar de não serem responsivas a antígenos específicos de Leishmania elas proliferam frente ao estímulo com mitógenos policlonais de linfócitos T. A restauração da resposta imune proliferativa nesses indivíduos pode ser feita através da adição de anticorpos monoclonais anti-IL10 ou ainda adicionando-se IFN-ץ à cultura de células isoladas desses pacientes (CARVALHO et al., 1989; CARVALHO et al., 1994; NYLEN et al., 2007b). Além disso, também foi visto que a produção elevada de citocinas do padrão Th2, como IL-4 e IL-13, estão relacionadas com a susceptibilidade e com o desenvolvimento de LV em humanos (BABALOO; KAYE; ESLAMI, 2001; THAKUR; MITRA; NARAYAN, 2003).

Uma população celular bem caracterizada como sendo importante fonte de citocinas supressoras são as células T reguladoras ( $\mathrm{T}$ regs). As células $\mathrm{T}$ regs naturais são diferenciadas no timo, e apresentam a marcação característica $\mathrm{CD}^{+}{ }^{+} \mathrm{CD} 25+\mathrm{FOXP3}^{+}$(SAKAGUCHI; WING; MIYARA, 2007). Elas medeiam a supressão de células do sistema imune inato e adquirido através da secreção de 
citocinas como IL-10 e TGF- $\beta$ (ASSEMAN et al., 1999), e também através do contato celular (FEHERVARI; SAKAGUCHI, 2004). Na infecção experimental de camundongos C57BL/6 com L. major há o recrutamento dessas células para a lesão (ANDERSON et al., 2007b; NAGASE et al., 2007) e, mediante produção de IL-10, as T regs são capazes de suprimir as atividades de células efetoras, favorecendo a sobrevivência dos parasitos (BELKAID et al., 2001a; BELKAID et al., 2002a). Além disso, em camundongos já curados da LC causada por parasitos da espécie L. major, a transferência de $\mathrm{T}$ regs é capaz de reativar a doença que estava latente, suprimindo respostas efetoras locais e permitindo que o parasito se replique novamente (MENDEZ et al., 2004). Na LV sabe-se que há migração de células $\mathrm{T}$ regs para o baço e fígado de animais infectados com L. infantum/chagasi (RODRIGUES et al., 2009), porém pouco se sabe sobre o efeito dessas células no sítio da inflamação, ou seja, se elas realmente desempenham papel supressor nesse contexto. Todavia, já se sabe que a IL-10, uma das principais citocinas produzidas pelas $\mathrm{T}$ regs, é relacionada com suscetibilidade à LV durante a infecção por L. donovani tanto em modelos experimentais como em humanos (MURPHY et al., 2001; NYLEN et al., 2007a). Levando em consideração que as células $T$ regs são uma das principais fontes de IL-10, estas podem estar intimamente envolvidas na patogênese da LV, mas ainda faltam estudos para confirmar tal hipótese. A literatura fornece dados de que as citocinas reguladoras, portanto, estão relacionadas com suscetibilidade 
em todos os tipos de leishmaniose, enquanto que a inflamação parece promover a morte dos parasitos através da indução de moléculas leishmanicidas.

As células Th17 foram descobertas em camundongos deficientes da subunidade p40 da IL-12 (CUA et al., 2003), e sua característica principal é a produção das citocinas IL-17A e F (MIOSSEC; KORN; KUCHROO, 2009), mas também é fonte de TNF, IL-21, e IL-22 (KREYMBORG et al., 2007; OUYANG; KOLLS; ZHENG, 2008; PARK et al., 2005). Para que ocorra a polarização para células Th17 é necessário um microambiente rico em IL-1 $\beta$, IL-6 e TGF- $\beta$ para a geração, e de IL-23 para manutenção desse padrão (AGGARWAL et al., 2003; KREYMBORG et al., 2007; VOLPE et al., 2008) (Figura 3).

A IL-17 se liga ao IL-17R, o qual é distribuído em vários tecidos, como pulmão, rim, fígado e baço (MOSELEY et al., 2003), sendo os dois últimos os principais locais de crescimento da L. infantum/chagasi e do dano patológico desencadeado pela infecção (WILSON et al., 1996). A ligação da IL-17 ao seu receptor desencadeia uma cascata bioquímica de sinalização que finda na ativação dos fatores de transcrição NF-kB e AP1, importantes mediadores das atividades de genes que codificam moléculas pró-inflamatórias (AWANE et al., 1999; SCHWANDNER; YAMAGUCHI; CAO, 2000) intimamente relacionadas à resistência à leishmaniose. 


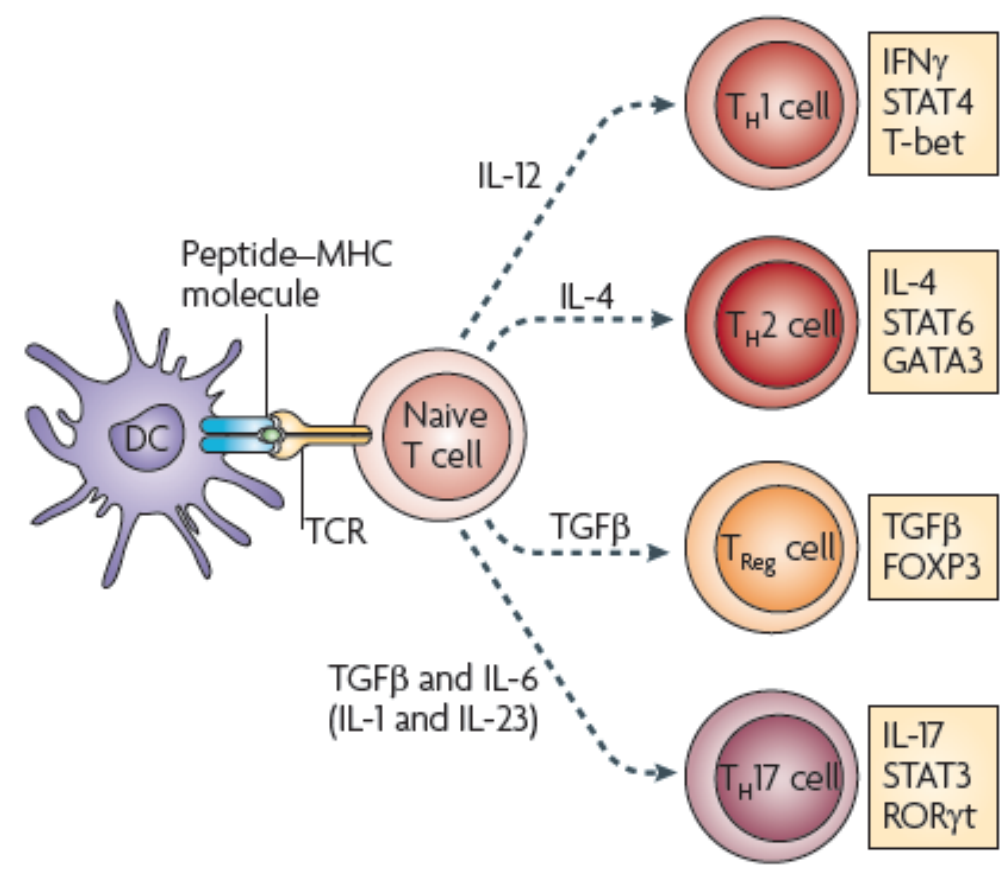

Figura 3: Polarização dos linfócitos T. Retirado de ZOU; RESTIFO, 2010.

As propriedades pró-inflamatórias da IL-17 tem sido demonstradas em muitos estudos, e incluem a indução de GM-CSF, IL-1, IL-6, IL-8, TNF, iNOS, metaloproteinases e quimiocinas (CXCL1, CXCL2, CXCL8, CXCL10) por fibroblastos, células endoteliais, macrófagos e células epiteliais, que acarreta em um intenso recrutamento de neutrófilos e consequente inflamação no tecido (KOLLS; LINDEN, 2004; NAKAE et al., 2003b; ZELANTE et al., 2007). Por esse motivo, inicialmente, as células Th17 foram associadas apenas com papéis patológicos em algumas doenças inflamatórias crônicas e auto-imunidades, como esquistossomose (RUTITZKY; STADECKER, 2006a), esclerose múltipla e 
sistêmica, psoríase, artrite reumatóide e lúpus eritematoso sistêmico (KURASAWA et al., 2000; LANGRISH et al., 2005; NAKAE et al., 2003a; WILSON et al., 2007; WONG et al., 2000). Porém, mais recentemente foi visto que sua ação pró-inflamatória também está relacionada ao bom prognóstico e à defesa de uma variedade de doenças infecciosas, como nas infecções por $C$. albicans e T. cruzi (CONTI et al., 2009; DA MATTA GUEDES et al., 2010; HUANG et al., 2004; MIYAZAKI et al., 2010), além de regular a progressão de alguns tumores (KRYCZEK et al., 2009; MURANSKI et al., 2008; VAN, V et al., 2009).

Embora as células Th17 tenham surgido como uma população de células essenciais que são capazes de regular o sistema imunológico e previnir o desenvolvimento de algumas doenças, pouco se sabe a respeito do envolvimento das células Th17 em infecções por parasitos protozoários. No caso específico das leishmanioses, os estudos ainda são controversos e pouco conclusivos, fornecendo subsídios para a realização de novas pesquisas que visam a elucidação completa de mecanismos envolvidos com a resposta Th17. Animais BALB/c com produção deficiente de IL-17 possuem maior resistência à infecção por L. major (LOPEZ et al., 2009), e a deleção do gene X-1 (IEX-1), um gene induzido por estresse, torna os animais C57BL/6 suscetíveis à infecção por L. major através da potencialização da produção de IL-17 por células Tүठ e Th17, além da diminuição da síntese de TNF (AKILOV et al., 2009). Em 
modelos de infecção por L. braziliensis a IL-17 parece ter função protetora, ao contrário do que ocorre na infecção por L. major, ambas as espécies causadoras de LC (NOVOA et al., 2011). Em 2009 foi demonstrado que o padrão inflamatório Th17 tem papel protetor durante a LV por L. donovani, uma vez que indivíduos assintomáticos são capazes de produzir altas quantidades de IL17 e IL-22, enquanto que os pacientes sintomáticos falham em produzir essas citocinas em humanos, indicando que além do padrão Th1 o padrão Th17 também atua na resistência nesse modelo (PITTA et al., 2009). Contudo, o papel desse subconjunto celular durante a infecção por L. infantum/chagasi permanece desconhecido. Assim, na intenção de clarear os entendimentos sobre o envolvimento de células Th17 na leishmaniose, o objetivo deste estudo foi avaliar se a população de linfócitos Th17 participa da defesa contra a $L$. infantum/chagasi e analisar quais os mecanismos envolvidos na suscetibilidade/resistência do hospedeiro mediante ativação de células Th17. 


\section{II) Objetivos}




\section{1) Objetivo geral}

Determinar a participação de linfócitos Th17 durante a infecção experimental por Leishmania infantum/chagasi.

\section{2) Objetivos específicos}

- Analisar a presença de citocinas que regulam a diferenciação de linfócitos Th17;

- Determinar a influência da L. infantum/chagasi na diferenciação de linfócitos Th17;

- Avaliar a importância das citocinas IL-6, IL-17, IL-22 e IL-23 na resposta imune contra a L. infantum/chagasi;

- Caracterizar a influência da citocina IL-17 sobre os padrões Th1 e Th2 de resposta imunológica e suas consequências durante a infecção por $L$. infantum/chagasi;

- Determinar o papel da citocina IL-17 na indução de moléculas leishmanicida. 


\section{III) Animais, \\ Material e Métodos}




\section{1) Animais}

Foram utilizados camundongos machos C57BL/6 WT e camundongos C57BL/ 6 geneticamente deficientes para as citocinas IL-23 (IL-23p19-/-), IL-6 (IL6/-), IL-10 (IL-10-/-) e para o receptor da citocina IL-17 (IL-17R-/-). Todos os camundongos utilizados para a experimentação tinham entre 7 e 8 semanas de idade. Os animais foram obtidos no biotério do Centro de Criação de Camundongos Especiais e Serviço de Biotério - USP, pesando entre 18 e 22 g, e ficaram no biotério dos departamentos de Imunologia e Bioquímica e Biologia Celular e Molecular e Bioagentes Patogênicos da Faculdade de Medicina de Ribeirão Preto - USP, onde foram mantidos em gaiolas, em um ambiente com temperatura controlada $\left(22\right.$ a $\left.25^{\circ} \mathrm{C}\right)$ com água e ração ad libitum. Todos os experimentos foram aprovados e conduzidos de acordo com o Comitê de Ética da Faculdade de Medicina de Ribeirão Preto, da Universidade de São Paulo, SP (aprovação sob protocolo número 121/2010).

\section{2) Parasitos}

Formas promastigotas de L. infantum/chagasi (isolado HU-USF 14), gentilmente cedidas pelo Prof. Dr. Roque Pacheco de Almeida, da Universidade Federal de Sergipe, foram mantidas a $25^{\circ} \mathrm{C}$ em meio Schneider (Sigma-Co, Saint 
Louis, EUA) suplementado com soro bovino fetal a 20\% (Cultilab, Campinas, SP Brasil), 2\% de urina humana masculina e 5\% de penicilina e estreptomicina (Sigma-Co, Saint Louis, EUA), em garrafas de cultura estéreis (Corning Incorporated, Corning, NY-EUA) e passadas serialmente em camundongos BALB/c para manutenção da virulência.

\section{3) Diferenciação de Células Dendríticas (BMDC) e Macrófagos} (ВMMФ) a Partir de Células Precursoras da Medula Óssea

As células dendríticas e macrofágos derivados da medula óssea de camundongos foram diferenciadas como previamente descrito por CARREGARO et al., 2008 e ENGLEN et al., 1995, respectivamente. Resumidamente, os camundongos C57BL/6 foram sacrificados e seus fêmures e tíbias cuidadosamente removidos, as epífises foram seccionadas em ambiente estéril e as medulas lavadas com meio de cultura RPMI incompleto utilizando seringa com agulha 13 × 4,5 mm estéreis. As células recém colhidas foram lavadas e centrifugadas a 300 x g por 10 minutos, eliminando-se o sobrenadante e incubando o sedimento com tampão de lise por 4 minutos à temperatura ambiente, sendo submetidos a um novo ciclo de centrifugação por 10 minutos após a adição de meio de cultura RPMI suplementado com 5\% de soro fetal bovino. Em seguida, as células precursoras foram cultivadas em meio RPMI 
completo suplementado com $10 \%$ de soro fetal bovino na presença de GM-CSF (30 ng/ml) e IL-4 (10 ng/ml) para diferenciação de células dendríticas, ou em meio RPMI completo suplementado com $10 \%$ de soro fetal bovino e $30 \%$ de sobrenadante de cultura de células L929 para diferenciação de macrófagos. As células foram distribuídas em placas próprias para cultivo celular (Corning Incorporated, Corning, NY-EUA) e mantidas em estufa a $37^{\circ} \mathrm{C}$ com $5 \%$ de $\mathrm{CO}_{2}$. Quatro dias após o início da diferenciação foi adicionado $10 \mathrm{~mL}$ do meio específico às culturas. Entre o sétimo e o nono dia de cultura as células foram analisadas por citometria de fluxo para determinar a expressão de F4/80, CD11b e CD11c, sendo o início dos experimentos realizado quando a porcentagem de

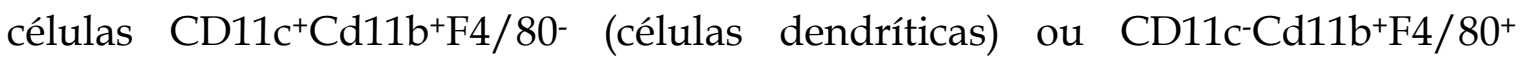
(macrófagos) foi maior ou igual a $80 \%$.

\section{4) Infecção de Células in vitro}

As culturas de BMDC e BMM $\phi$ foram ajustadas para uma concentração de $1,0 \times 10^{6} / \mathrm{mL}$ em meio RPMI acrescido de $10 \%$ de soro fetal bovino, $2 \mathrm{mM}$ de glutamina, $25 \mathrm{mM}$ de HEPES $\mathrm{pH}$ 7,2, $50 \mu \mathrm{M}$ de 2-mercaptoetanol e 100 unidades/mL de penicilina. As células foram distribuídas em placas de 24 poços (Corning Incorporated, Corning, NY-EUA), sendo $500 \mu \mathrm{L}$ por poço, e mantidas em repouso durante 90-120min. Posteriormente, foram infectadas com $L$. 
infantum/chagasi (5 parasitos:1 célula), ou cultivadas como controles não infectados. As culturas foram mantidas em estufa com $5 \%$ de $\mathrm{CO}_{2}$ a $37^{\circ} \mathrm{C}$ por $8 \mathrm{~h}$, no caso de células dendríticas utilizadas para PCR em tempo real, ou por $12 \mathrm{~h}$ no caso de células dendríticas cujo sobrenadante foi utilizado para ELISA, ou por 48 h para dosagem de NO nas culturas de macrófagos.

\section{5) Separação de Células do Baço e Ensaio de Co-cultura}

Baços de camundongos C57BL/6 WT não infectados ou infectados foram removidos para o isolamento dos leucócitos. Após remoção, o órgão foi macerado e posteriormente centrifugado a $300 \mathrm{X} \mathrm{g}$ durante $10 \mathrm{~min}$ a $4^{\circ} \mathrm{C}$. As células obtidas foram incubadas com tampão de lise a $37^{\circ} \mathrm{C}$ durante 4 minutos. A reação foi bloqueada acrescentando-se meio RPMI suplementado com $10 \%$ de soro fetal bovino, as células lavadas duas vezes em meio RPMI incompleto e então ressuspensas em RPMI 10\%. As células foram diluídas em Azul de Tripan para quantificação e análise de viabilidade com auxílio da Câmara de Neubauer.

Os linfócitos do baço de animais não infectados foram estimulados com a-CD3 (2 $\mu \mathrm{g} / \mathrm{mL}$ ) e co-cultivados com BMDCs infectadas com L. infantum/chagasi (5 linfócitos: 1 BMDC), sendo um total de $5 \times 10^{5}$ células/poço/200 $\mu \mathrm{L}$ em placas de cultura de 96 poços de fundo chato (Corning Incorporated, Corning, NY-EUA), mantidas em estufa de $37^{\circ} \mathrm{C}$ contendo $5 \%$ de $\mathrm{CO}_{2}$ por 96 h. Após esse período, as 
células foram coletadas, marcadas com anticorpos anti-CD3, anti-CD4, anti-CD8 e anti-IL-17 conjugados a distintos fluorocromos e posteriormente analisadas por citometria de fluxo.

\section{6) Infecção Experimental}

Camundongos machos com 7 ou 8 semanas de idade foram infectados por via intravenosa (iv) através da veia do plexo orbital com $1 \times 10^{7}$ formas promastigotas em fase estacionária de crescimento de L. infantum/chagasi.

\section{7) Análise da Carga Parasitária dos Animais}

Para estudar a capacidade dos camundongos em eliminar o agente infeccioso, o fígado e o baço de camundongos WT e knockouts infectados durante 4, 6 e 8 semanas foram removidos, pesados e a porção inferior do baço e o lóbulo esquerdo do fígado, após pesados, foram triturados em um volume de $2 \mathrm{~mL}$ de meio de cultura Schneider incompleto. O volume total foi centrifugado a 3000 $\mathrm{rpm}, 25^{\circ} \mathrm{C}, 10$ minutos e ressuspenso em $1 \mathrm{~mL}$ de Schneider 20\%. Posteriormente, as diluições seriadas foram feitas em placas estéreis de 96 poços de fundo chato, conforme a técnica de diluição limitante descrita anteriormente por TITUS et al., 1985. As contagens dos poços positivos foram realizadas no dia 15 após a 
diluição nas placas e o número de parasitos foi estimado como descrito por BUFFET et al., 1995.

\section{8) Antígeno Particulado de L. infantum/chagasi, Cultura de Células do}

\section{Baço e Fígado}

As culturas do parasito foram mantidas conforme descrito anteriormente. Os parasitos foram coletados quando atingiram a fase estacionária de crescimento e foram submetidos a 10 ciclos de congelamento $\left(-196^{\circ} \mathrm{C}\right.$ em nitrogênio líquido) e descongelamento $\left(56^{\circ} \mathrm{C}\right.$ em banho-Maria). As proteínas foram dosadas em NanoDrop ${ }^{\mathrm{TM}} 2000$ (Thermo Fisher Scientific, EUA) e utilizadas para estimulação das culturas celulares. As células do baço de camundongos infectados durante 4 e 6 semanas ou não infectados foram coletadas como descrito anteriormente. As células do fígado foram obtidas de camundongos com esse mesmo período de infecção. O órgão foi processado em meio RPMI e filtrado em Cell Strainers (BD Biosciences, San Diego, CA, EUA). O conteúdo foi centrifugado e submetido ao gradiente de Ficoll-Paque ${ }^{\mathrm{TM}}$ PLUS (Science Pro, São Caetano do Sul, SP, Brasil) para separação dos leucócitos. Após esse procedimento, as células foram lavadas 2 vezes com PBS 1X e então diluídas em Azul de Tripan para quantificação e análise da viabilidade celular com auxílio da Câmara de Neubauer. As células do baço e fígado foram plaqueadas em 
microplacas de 48 poços (Corning Incorporated, Corning, NY-EUA) na densidade de 2,5×106 células viáveis/poço em um volume final de $500 \mu \mathrm{L}$ e estimuladas com $50 \mu \mathrm{g} / \mathrm{mL}$ de antígeno particulado por poço. As culturas foram mantidas por $72 \mathrm{~h}$ em estufa contendo $5 \%$ de $\mathrm{CO}_{2}$ a $37^{\circ} \mathrm{C}$. Após esse período, o sobrenadante foi coletado para análise da produção de citocinas através de ELISA e as células foram utilizadas para análise por citometria de fluxo.

\section{9) Dosagem de Citocinas por ELISA}

As concentrações das citocinas foram mensuradas no sobrenadante das culturas de BMDC infectadas, ou não, in vitro, bem como no sobrenadante das culturas de células do baço dos animais infectados por 4 e 6 semanas estimuladas com antígeno bruto particulado de L. infantum/chagasi ou com meio de cultura somente, para controle negativo. Pedaços do fígado e do baço dos animais infectados por 4 e 6 semanas e de animais não infectados foram pesados e triturados em inibidor de protease Complete (Hoffmann-La Roche Ltd ${ }^{\mathrm{TM}}$, EUA) para quantificação de citocinas. A dosagem foi realizada através de ensaio imunoenzimático (ELISA) do tipo sandwich, utilizando-se kit comercial (OpTEIA, BD Biosciences, San Diego, CA, EUA) seguindo as recomendações do fabricante. A leitura da reação colorimétrica foi realizada a $450 \mathrm{~nm}$ em leitor de microplacas (EMAX, Molecular Devices Corporation, Sunnyvale, CA, USA) e as 
concentrações das citocinas foram determinadas a partir dos valores obtidos com a curva-padrão realizada com as diferentes diluições conhecidas da proteína recombinante fornecida pelo kit.

\subsection{0) Determinação do Padrão de Citocinas por Citometria de Fluxo}

Além da determinação do perfil de citocinas dos animais WT e knockouts através do ELISA, as células foram analisadas por citometria de fluxo para marcação de citocinas intracelulares. Brevemente, as células foram mantidas em cultura por $72 \mathrm{~h}$, conforme descrito anteriormente, quando então foi adicionada à cultura PMA (20 ng/poço), ionomicina (500 ng/mL) e brefeldina A (100 ng/mL) sendo as células cultivadas por mais $6 \mathrm{~h}$ em estufa com $5 \%$ de $\mathrm{CO}_{2}$ a $37^{\circ} \mathrm{C}$. Após esse período, as células foram coletadas e incubadas com $100 \mu \mathrm{L}$ de soro de coelho a 10\% diluído em PBS (para bloquear possíveis ligações inespecíficas dos anticorpos aos receptores $\mathrm{Fc}_{\mathrm{C}}$ na superfície da célula) por 30 minutos a $4^{\circ} \mathrm{C}$ e em seguida foi adicionado $1,0 \mu \mathrm{L}$ de anticorpos monoclonais específicos para as moléculas de superfície CD3, CD4 e CD8 conjugados com os fluorocromos FITC, PE-Cy7 e PERCP, (BD Bioesciences e eBioscience, San Diego, CA, EUA). As células foram incubadas 30 minutos a $4^{\circ} \mathrm{C}$ com os anticorpos de moléculas de superfície e então foram lavadas 2 vezes com PBS antes do início do processo de permeabilização. Para tal, as células foram incubadas com Cytofix/Cytoperm 
(BD Bioesciences e eBioscience, San Diego, CA, EUA) por 20 minutos a $4^{\circ} \mathrm{C}$, lavadas em Perm/Wash 1X (BD Bioesciences, San Diego, CA, EUA) e incubadas durante 30 minutos a $4^{\circ} \mathrm{C}$ com os anticorpos para marcações de moléculas intracelulares anti-IL-17, anti-IFN-ץ e anti-IL-10 conjugados com os fluorocromos PE, APC e ALEXA647 (BD Bioesciences e eBioscience, San Diego, CA, EUA). Após incubação, as células foram lavadas 2 vezes com Perm/Wash $1 \mathrm{X}$ e então adquiridas no aparelho FACSCanto II (BD Biosciences, San Diego, CA, EUA). Os dados foram analisados com auxilio do software FlowJo (Tree Star Inc, OR EUA).

\subsection{1) Extração de RNA total e confecção do DNA complementar (cDNA)}

O RNA total foi extraído das culturas de BMDCs infectadas e controles e de fragmentos do fígado e baço de camundongos C57BL/ 6 WT coletados após 2, 4, 6 e 8 semanas de infecção e de controles não infectados. O método de extração combinou a utilização de TRIzol (Invitrogen Corporation-Carlsbad, USA) seguida pela utilização parcial do kit de extração Illustra RNAspin Mini (GE Healthcare, Alemanha). Resumidamente, após coleta do órgão, um fragmento de aproximadamente $100 \mathrm{mg}$ de tecido foi armazenado em $500 \mu \mathrm{L}$ de reagente TRIzol a $-70^{\circ} \mathrm{C}$ até o momento da extração. $\mathrm{O}$ tecido foi então descongelado e triturado com auxílio de haste homogenizadora livre de RNAse seguido da adição de mais $500 \mu \mathrm{L}$ de TRIzol e 5 minutos de repouso a temperatura ambiente. 
Após esse período, foi adicionado $200 \mu \mathrm{L}$ de clorofórmio e a solução foi agitada durante 15 segundos e centrifugada a $10000 \times$ g por 10 minutos a $4^{\circ} \mathrm{C}$. A porção aquosa superior foi removida e utilizada para prosseguimento da extração pelo kit Illustra RNAspin Mini de acordo com o protocolo fornecido pelo fabricante. Após extração, o RNA foi quantificado e avaliado quanto a pureza e qualidade com auxílio do NanoDrop ${ }^{\mathrm{TM}}$ 2000. O RNA extraído foi submetido à confecção do cDNA. Para isso, inicialmente todas as amostras foram diluídas para concentrações semelhantes e conhecidas e depois foi adicionado $1 \mu \mathrm{L}$ de Oligo $(\mathrm{dT})_{12-18}$ à $2 \mu \mathrm{g}$ do RNA mais $\mathrm{H}_{2} \mathrm{O}$ livre de RNAse para completar um volume final de $13 \mu \mathrm{L}$. Esse volume foi então incubado a $65^{\circ} \mathrm{C}$ por 5 minutos em termociclador PTC-100 (MJ Research, Watertown, EUA) seguido por uma incubação no gelo por 1 minuto. À reação foi adicionado um mix contendo $4 \mu \mathrm{L}$ de tampão da enzima, $1 \mu \mathrm{L}$ de DTT 0,1 mM, $1 \mu \mathrm{L}$ de dNTP $10 \mathrm{mM}$ e $1 \mu \mathrm{L}$ da enzima Transcriptase Reversa SuperScript ${ }^{\mathrm{TM}}$ III (Invitrogen CorporationCarlsbad, USA) (200 U/ $\mu \mathrm{L})$, totalizando $20 \mu \mathrm{L}$ de volume final. A reação foi incubada a $50^{\circ} \mathrm{C}$ por 60 minutos e depois a $70^{\circ} \mathrm{C}$ por 10 minutos. O cDNA foi diluído 10 vezes em água estéril e foi armazenado a $-70^{\circ} \mathrm{C}$ até o momento do uso. 


\subsection{2) PCR em Tempo Real}

A análise relativa de transcritos de genes alvos foi realizada por PCR em tempo real utilizando-se do cDNA confeccionado a partir das amostras supracitadas. A reação foi realizada com 6,5 $\mu \mathrm{L}$ de SYBER Green Mix (Invitrogen Corporation-Carlsbad, USA), $0,5 \mu \mathrm{L}$ de cada primer (senso e antisenso) a $10 \mu \mathrm{M}, 5$ $\mu \mathrm{L}$ do cDNA sintetizado a partir de $2 \mu \mathrm{g}$ de RNA extraído e água destilada estéril suficiente para completar o volume final para $15 \mu \mathrm{L}$. A reação foi feita em aparelho StepOnePlus ${ }^{\mathrm{TM}}$ Real-Time PCR Systems (Applied Biosystems, EUA) compreendendo 2 minutos a $50^{\circ} \mathrm{C}, 2$ minutos a $95^{\circ} \mathrm{C}$ e 40 ciclos de 15 segundos a $95^{\circ} \mathrm{C}$ - 30 segundos a $58^{\circ} \mathrm{C}-30$ segundos a $72^{\circ} \mathrm{C}$. Um ciclo final de 20 minutos com temperatura crescente de 60 a $95^{\circ} \mathrm{C}$ foi empregado para obtenção da curva de dissociação dos produtos da reação, utilizada para análise da especificidade da amplificação. Todas as reações foram feitas em duplicatas, os resultados foram normalizados com o HPRT constitutivamente expresso e analisados com base no valor de Ct (cicle threshold) ou linha de corte. O resultado foi calculado com a fórmula $\Delta \Delta \mathrm{Ct}=\Delta \mathrm{Ct}$ da amostra $-\Delta \mathrm{Ct}$ da amostra controle, onde $\Delta \mathrm{Ct}=\mathrm{Ct}$ gene estudado - Ct HPRT. O número de vezes de expressão diferencial do RNA mensageiro comparado com o controle foi definido pela fórmula $2^{-\Delta \Delta \mathrm{Ct}}$. Os primers e sequências utilizados durante a reação de PCR em tempo real estão listados na Tabela 1. 
Tabela 1: Sequência dos primers utilizados nas reações de PCR em tempo real.

\section{SEQUÊNCIAS}

\begin{tabular}{ccc}
\hline Gene & Senso & Antisenso \\
& TGGAAAAGCCAAATACAAAGC & CAACATCAACAGGACTCCTCG
\end{tabular}

\begin{tabular}{ccc}
\hline IL-6 & TTCCTACCCCAATTTCCAAT & CCTTCTGTGACTCCAGCTTATC \\
IL-23p19 & AATGTGCCCCGTATCCAGTGT & GGCTCCCCTTTGAAGATGTCA \\
TGF- $\boldsymbol{\beta}$ & ACCGCAACAACGCCATCTAT & TCAAAAGACAGCCACTCAGGC \\
\hline IL-1 $\boldsymbol{\beta}$ & ATGGGCTGGACTGTTTCTAATG & ATTCACGAAAAGGGAGCTCC \\
\hline IL-17 & TGCCCTCCACAATGAAAAGA & AACACGAAGCAGTTTGGGAC \\
\hline
\end{tabular}

\subsection{3) Análise Histopatológica do Fígado}

Para análise histopatológica, amostras de tecido hepático foram fixadas em formaldeído a $10 \%$, por $48 \mathrm{~h}$, e depois transferidos para álcool $70 \%$. As amostras foram submetidas a uma bateria de desidratação em soluções com concentrações crescentes de álcool e xilol, e então foram incluídas em parafina, cortadas com auxílio do micrómetro ( 5 um de espessura) e dispostos em lâminas. As lâminas foram incubadas a $60^{\circ} \mathrm{C}$ para fixação do corte e em seguida foram lavadas em 
xilol para retirar o excesso de parafina, e hidratados com concentrações decrescentes de álcool (do absoluto ao álcool 70\%). Os cortes foram então corados com Hematoxilina e Eosina (H\&E), desidratados com concentrações crescentes de álcool (do álcool 70\% ao absoluto), lavados com xilol e montados em lamínula com Bálsamo do Canadá (Vetec Química, Rio de Janeiro, Brasil). As imagens foram obtidas em microscópio ótico em aumento de 10X e 40X. Foram fotografados 50 campos aleatórios de cada corte e as imagens foram analisadas e descritas comparativamente. A medição da área da lesão (área de infiltrado inflamatório) foi feita com auxílio do programa Leica QWin - Quantitative Imaging (Leica Microsystems).

\subsection{4) Ensaio de Proliferação por Diluição de CFSE}

As células inflamatórias dos animais WT e IL-17R-/- foram incubadas com $5 \mu \mathrm{M}$ de CFSE diluído em PBS $1 \mathrm{X}$ por 10 minutos a $37^{\circ} \mathrm{C}$. A reação foi bloqueada com RPMI 5\% a $4^{\circ} \mathrm{C}$, e as células foram lavadas duas vezes. Após marcação, as células foram cultivadas na presença de meio de cultura (controle negativo) e conA $(20 \mu \mathrm{g} / \mathrm{mL})$ por $96 \mathrm{~h}$ em placa de 96 poços de fundo chato. Após esse período, a proliferação dos linfócitos foi mensurada através de leitura em FACSCanto II. 


\subsection{5) Obtenção do Soro e Dosagem Bioquímica de Transaminase}

\section{Glutâmico-Oxalacética}

O sangue foi coletado via punção retro-orbital dos animais C57BL/6 WT e IL-17R-1- não infectados, e após 4 e 6 semanas de infecção. O soro foi obtido através da centrifugação do sangue total a 1000 x g por 5 minutos e foi dividido em alíquotas de $100 \mu \mathrm{L}$, congelado a $-20^{\circ} \mathrm{C}$ até o momento do uso. Para avaliar a magnitude da lesão no fígado dos animais, foi feita a dosagem da transaminase oxalacética (TGO). A concentração sérica foi determinada por método colorimétrico pela reação de Reitman Frankel seguindo os procedimentos recomendados pelo fabricante (Labtest Diagnóstica AS, MG, Brasil).

\subsection{6) Avaliação da Produção de Óxido Nítrico por Macrófagos}

\section{Infectados}

Após a diferenciação, os macrófagos foram distribuídos em placas de 24 poços previamente ocupados por lamínulas de vidro estéreis e livres de LPS. Foram plaqueados $2 \times 10^{6}$ células/poço em um volume total de $300 \mu \mathrm{L}$. As células foram mantidas em repouso durante 90-120 minutos para a aderência e então os macrófagos WT foram tratados com 0,10 e $100 \mathrm{ng} / \mathrm{mL}$ de IFN- $\gamma$ recombinante e 0, 30, 100 e $300 \mathrm{ng} / \mathrm{mL}$ de IL-17 recombinante, bem como com as combinações de ambas citocinas em todas as concentrações estudadas, durante 
16 h. Macrófagos WT tratados e não tratados com os recombinantes foram infectados com promastigotas em fase estacionária de crescimento de $L$. infantum/chagasi (5 parasitos:1 célula), decorridas 6 horas as culturas foram lavadas para remoção dos parasitos que não foram fagocitados pelos macrófagos. Após 48 h de infecção, o sobrenadante foi coletado para quantificação da produção de NO pelos macrófagos através da mensuração de nitrito (NO2-). Para isso, $50 \mu \mathrm{L}$ de reagente de Griess (diamina di-hidroclorido naftaleno - NEED) a 0.1\% (Sigma-Aldrich, EUA) diluído em água destilada e sulfanilamida a 1\% (Sigma-Aldrich, EUA) diluída em ácido fosfórico a 5\% (Merck S.A., Rio de Janeiro, RJ) foi adicionado a $50 \mu \mathrm{L}$ do sobrenadante a reação foi lida imediatamente na densidade óptica (DO) de $540 \mathrm{~nm}$ em leitor de miniplacas (EMAX, Molecular Devices Corporation, Sunnyvale, CA, USA). Os resultados foram expressos em $\mathrm{mM}$ sendo determinados pela comparação com a curvapadrão, obtida pelo uso de nitrito de sódio (Vetec Química, Rio de Janeiro, Brasil) em concentrações de 200 a $0,9 \mu \mathrm{M}$.

\subsection{7) Imunofluorescência}

Os tecidos hepáticos de camundongos WT e IL-17R-/- não infectados e de animais após 4 e 6 semanas de infecção foram congelados em Tissue-Tek® (Sakura Finetek Inc., Torance, USA) e isopentano a $-70^{\circ} \mathrm{C}$. Os cortes foram feitos a 
5,0 $\mu \mathrm{m}$ e fixados em lâminas previamente banhadas em poli-L-lisina. Brevemente, as lâminas contendo os cortes obtidos do fígado foram fixadas em triton-X-100 0,5\% diluído em PBS por 5 minutos e posteriormente em glicina $0.1 \mathrm{M}$ por 30 minutos à temperatura ambiente. Após esse período foi realizado o bloqueio dos sítios inespecíficos com soro de coelho por 30 minutos e o anticorpo primário anti-iNOS foi incubado overnight sobre o corte do tecido. Em seguida, os cortes foram lavados em PBS e adicionado o anticorpo secundário conjugado com FITC diluído em HEPES 0.1 M por 1 hora à temperatura ambiente. O DAPI (300 nM) foi utilizado para a marcação do núcleo. As lâminas foram montadas com prolong, vedadas com esmalte incolor e mantidas no escuro a $4^{\circ} \mathrm{C}$ até o momento da análise. Os resultados são expressos quanto à intensidade da fluorescência. E as imagens foram analisadas com auxílio do programa Leica QWin - Quantitative Imaging (Leica Microsystems).

\subsection{8) Análise Estatística}

Os resultados estão representados como média \pm desvio padrão (DP). Diferenças estatísticas foram determinadas utilizando-se o teste $\mathrm{t}$ de Student ou a análise de variância (ANOVA) seguida pelo pós-teste de Bonferroni para amostras com distribuições normais. As análises foram feitas com auxílio do GraphPad-Prism (GraphPad Software Inc., San Diego CA, EUA) e foram 
Animais, Material e Métodos

consideradas estatisticamente significativas as diferenças que apresentaram valores de P igual ou menor a 0,05. 
IV) Resultados 


\section{1) A infecção por L. infantum/chagasi dirige a resposta imune adaptativa para o perfil Th17}

As células dendríticas são as principais células responsáveis pela apresentação antigênica com os co-estímulos necessários para indução da resposta imune adaptativa. Dessa forma, com o intuito de avaliar o efeito da $L$. infantum/chagasi na indução dos fatores necessários para a polarização dos linfócitos para o perfil Th17, BMDCs foram infectadas in vitro com parasitos em fase estacionária de crescimento ( 5 parasitos: 1 célula) por 8 horas, quando então as células foram coletadas e armazenadas em reagente TRIzol para extração do mRNA, confecção do cDNA e performance do PCR em tempo real; ou por 12 horas para coleta do sobrenadante das culturas utilizado para ensaios de ELISA. Observou-se que, após a infecção, a expressão do mRNA para tgf- $\beta$ foi aumentada em 7 vezes $(\mathrm{P}<0,0002)$ e para $i l-6$, il-23p19 e $i l-\beta$ o aumento foi de, respectivamente, 2,3; 2,5 e 1,7 ( $\mathrm{P}<0,0025 ; \mathrm{P}<0,0231$ e $\mathrm{P}<0,0005)$ (Figura 4A). Além disso, o ELISA comprovou a produção aumentada das proteínas IL-6, IL23p19 e IL-1 $\beta$ por BMDCs infectadas (Figura 4B). Esses dados demonstram, portanto, que houve uma regulação positiva tanto da expressão do mRNA quanto da produção das proteínas envolvidas na geração e manutenção do padrão Th17. 
A

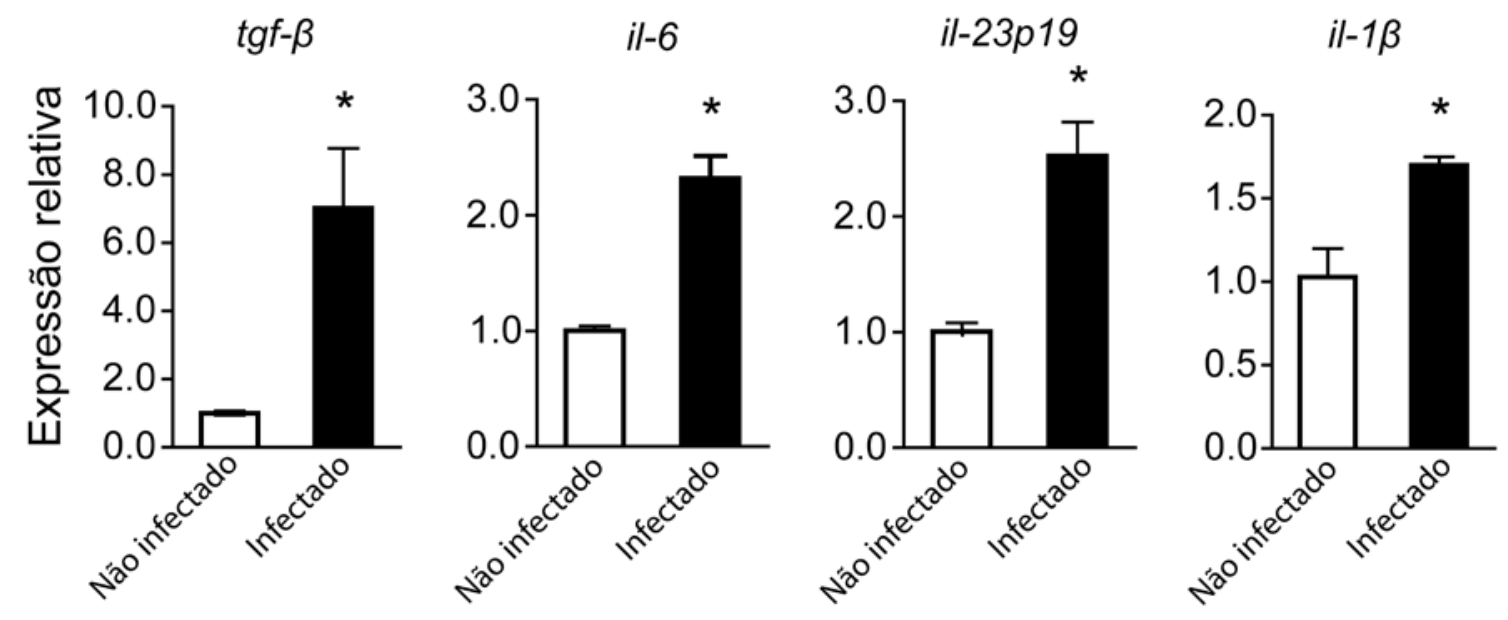

B

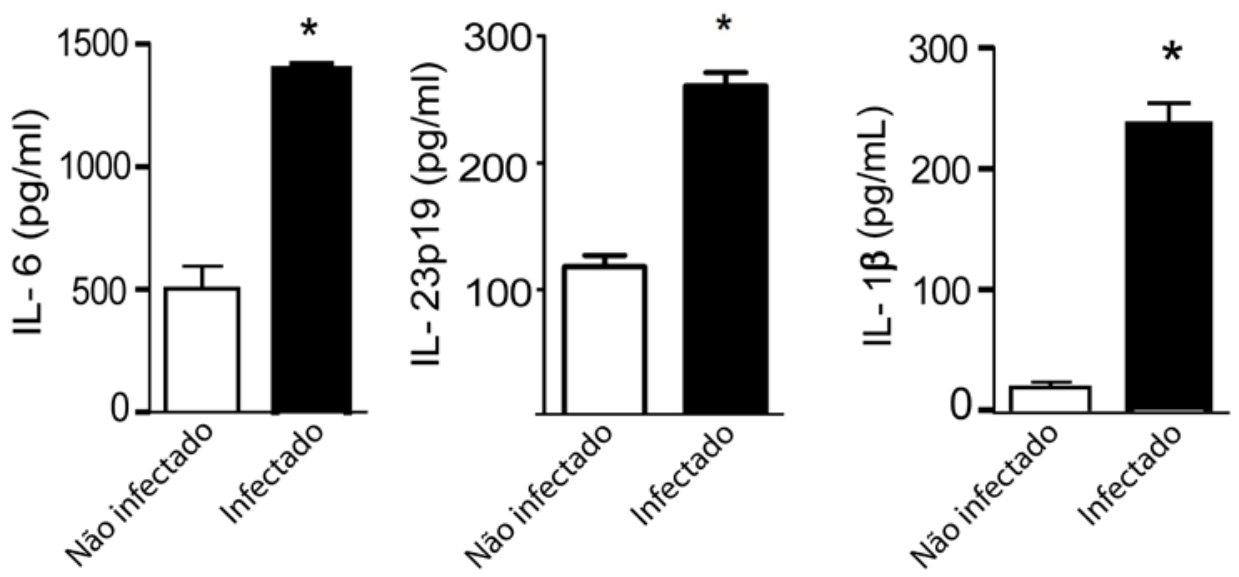

Figura 4: L. infantum/chagasi induz a liberação dos fatores necessários para polarização dos linfócitos para o padrão Th17. BMDCs $\left(2,0 \times 10^{6}\right.$ células $\left./ \mathrm{mL}\right)$ foram infectadas (barras pretas) ou não (barras brancas) com L. infantum/chagasi em fase estacionária de crescimento (5 parasitos: 1 célula). (A) A expressão de mRNA para $t g f-\beta, i l-6, i l-23 p 19$ e $i l-1 \beta$ foi avaliada 8 h após a infecção das células por PCR em tempo real e normalizada de acordo com a expressão constitutiva do HPRT na célula. (B) Após 12 h de infecção, os sobrenadantes das culturas foram coletados para análise da secreção das proteínas IL-6, IL-23p19 e IL-1 $\beta$ por ELISA. Os dados são representtivos de dois experimentos independentes ( $\mathrm{N}=6$ por grupo) e são expressos como média \pm DP. * $\mathrm{P}<0,05$ comparado ao grupo controle não infectado. 
Consistente com essa observação, células do baço de camundongos C57BL/6 não infectados quando co-cultivadas com BMDCs infectadas, sob estímulo com a-CD3, aumentaram a expressão da citocina IL-17 de 0,31\% para 0,63\%, comparadas com os linfócitos co-cultivados com BMDCs não infectadas, também na preseça de a-CD3 (Figuras 5A e B). O aumento observado na média de intensidade de fluorescência da expressão de IL-17, de 1.123,23 nos linfócitos co-cultivados com BMDCs não infectadas para 1.628,4 nos linfócitos cocultivados com BMDCs infectadas, evidencia que, além de possuírem mais células produtoras de IL-17, essas células produzem maior quantidade desta citocina (Figura 5C), demonstrando que o parasito é capaz de induzir a polarização de linfócitos para o padrão Th17 in vitro.

Para avaliar se esse evento também ocorria durante o modelo in vivo de infecção, a partir de amostras de baço e fígado de camundongos C57BL/6 infectados com L. infantum/chagasi, nós realizamos uma cinética da expressão de mRNA para a citocina il-17 até 8 semanas após a infecção. Foi observado que a infecção in vivo também induziu a expressão de mRNA para il-17 nos órgãos alvo da LV, baço e fígado, sendo o pico de expressão atingido na quarta e sexta semanas após a infecção (Figura 6A). Com base nisso, nós avaliamos a produção da proteína nos órgãos estudados e no sobrenadante da cultura de células do baço restimuladas com antígeno bruto de L. infantum/chagasi por 72 horas. Foi verificada uma produção significativa de IL-17, a principal citocina 
Resultados

A

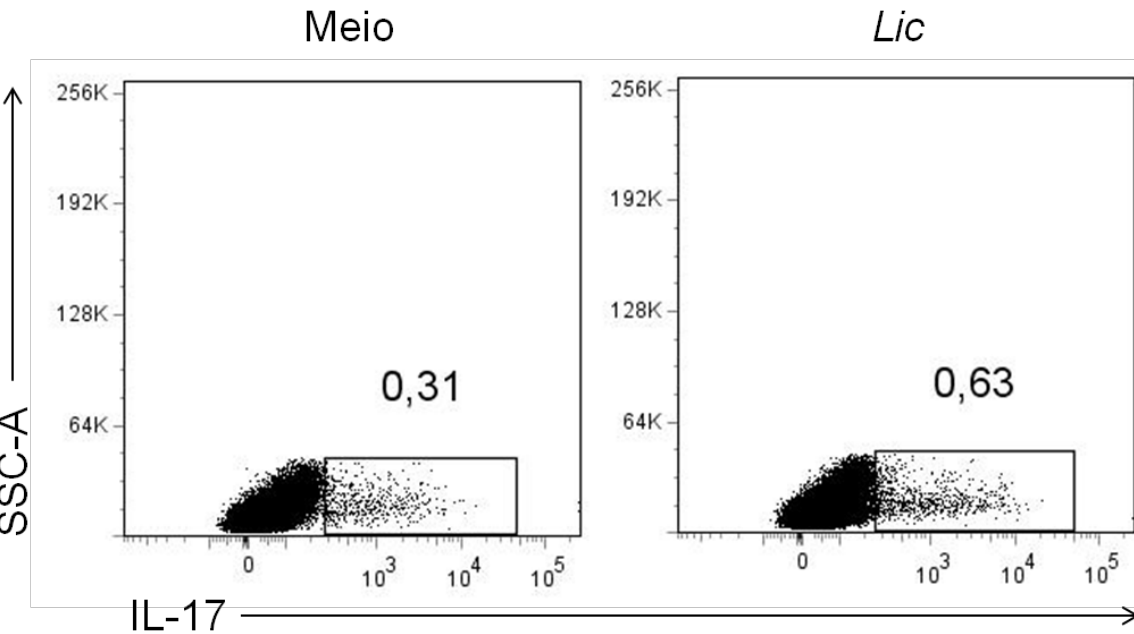

B
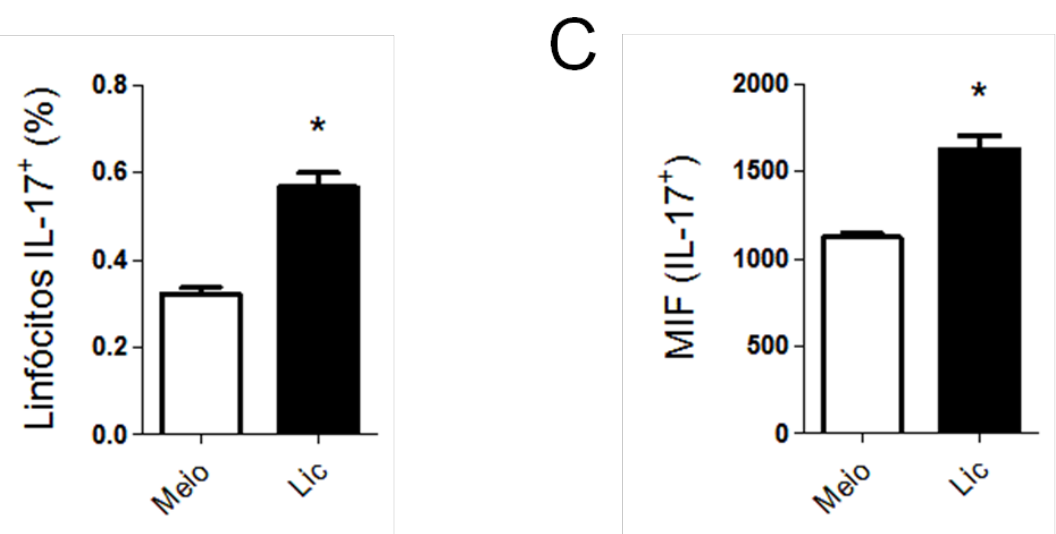

Figura 5: L. infantum/chagasi polariza linfócitos de camundongos C57BL/6 naïves para o perfil Th17. Células do baço de camundongos C57BL/6 naïves foram co-cultivadas com BMDCs infectadas com L. infantum/chagasi (5 parasitas: 1 BMDC: 5 linfócitos), na presença de a-CD3 $(2 \mu \mathrm{g} / \mathrm{ml})$ por $96 \mathrm{~h}$. (A) Os dot-plots exibem o resultado representativo da porcentagem de células $\mathrm{IL}-17^{+}$determinada por citometria de fluxo dentro da população de linfócitos, demonstrada em B pelo gráfico de barras. (C) A média de intensidade de fluorescência foi calculada com auxílio do software Flow Jo. As barras pretas representam co-culturas de linfócitos com BMDCs infectadas e as barras brancas representam co-culturas de linfócitos com BMDCs não infectadas, utilizadas como controle (Meio). Os resultados são representativos de dois experimentos independentes e estão expressos como média $\pm \mathrm{DP},{ }^{*} \mathrm{P}<0,05$ comparado ao grupo controle não infectado (Meio). Lic, L. infantum/chagasi. 
relacionada com o padrão Th17 de resposta, sendo esses níveis de aproximadamente $1.300 \mathrm{pg} / \mathrm{mL}$ no fígado, nos dois períodos observados, e de 60 pg/mL no baço, após 4 semanas de infecção, e 145 pg/mL no baço após 6 semanas de infecção (Figura 6B). Esse dado foi corroborado com a regulação positiva e significativa da produção de IL-17 por células do baço de camundongos após 4 e 6 semanas de infecção reestimuladas em cultura (Figura 6C), mostrando que a infecção por L. infantum/chagasi é capaz de induzir efetivamente o perfil Th17 de resposta imune adaptativa em modelo de infecção in vivo.

\section{2) Células Th17 desempenham papel crítico no controle da infecção}

\section{por L. infantum/chagasi}

Baseando-se em observações prévias de que o perfil Th17, 1) possui propriedades inflamatórias (KOLLS; LINDEN, 2004; NAKAE et al., 2003b; ZELANTE et al., 2007), 2) está envolvido na proteção contra alguns parasitos (BETTELLI et al., 2008; VAN, V et al., 2009), 3) ter o seu papel ainda indefinido durante as leishmanioses, e 4) além do fato de que a L. infantum/chagasi induz esse perfil no decorrer a infecção no hospedeiro vertebrado, nós estávamos interessados em saber o papel da citocina IL-17 durante a LV por L. infantum/chagasi. Para isso, animais IL-17R-/- e camundongos do tipo selvagem, 
A

Fígado

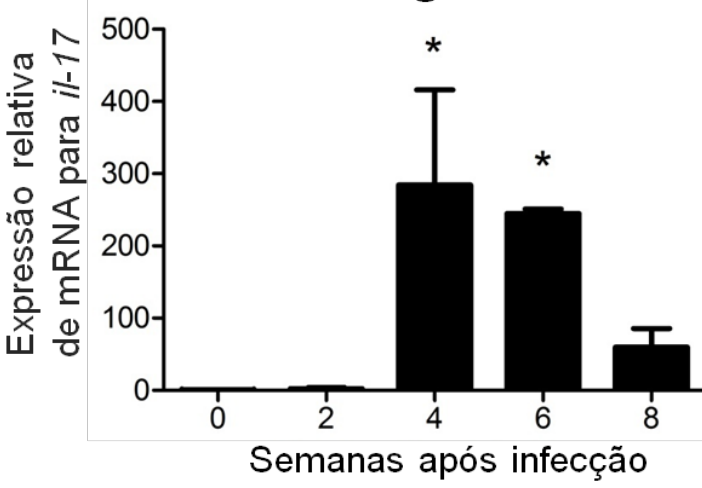

$\mathrm{B}$

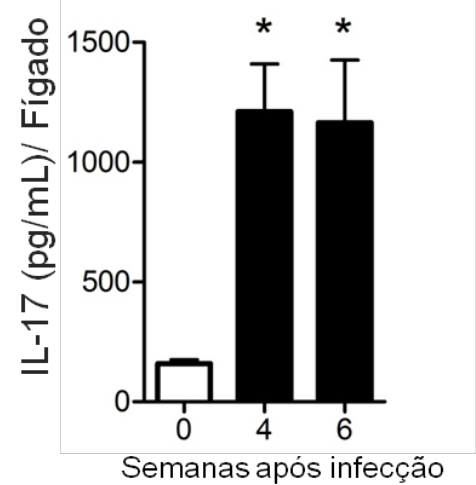

Baço

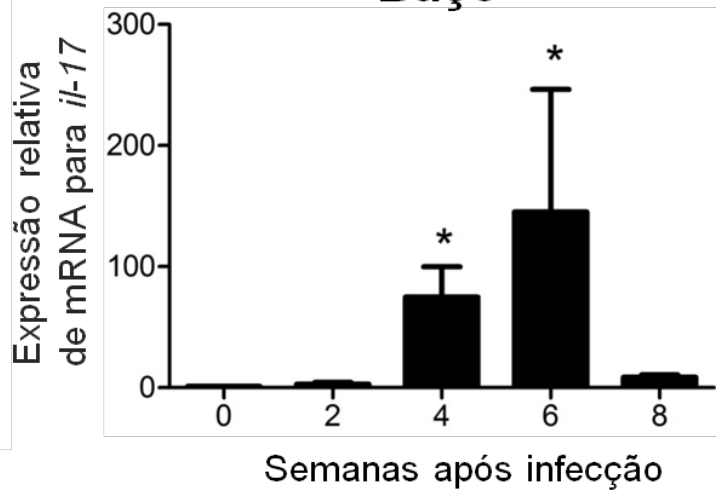

C
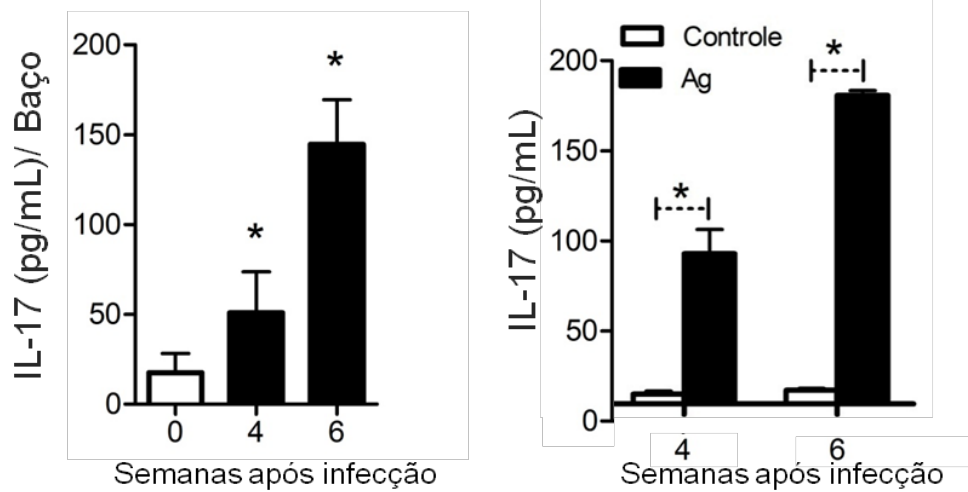

Figura 6: L. infantum/chagasi induz a produção de IL-17 in vivo nos órgãos alvo da inflamação. Camundongos C57BL/6 foram infectados iv com $1 \times 10^{7}$ parasitos em fase estacionária de crescimento. O baço e fígado foram coletados nos tempos indicados. (A) A expressão do mRNA para il-17 foi determinada por PCR em tempo real e normalizada de acordo com a expressão constitutiva do HPRT na célula. (B) A concentração da citocina IL-17 em homogenatos do baço e fígado e (C) no sobrenadante da cultura de células do baço reestimuladas com antígeno bruto de L. infantum/chagasi $(50 \mu \mathrm{g} / \mathrm{mL})$ por $72 \mathrm{~h}$ foi mensurada por ELISA. Os resultados são representativos de dois experimentos independentes $(N=4)$ e são expressos como a média \pm DP. * $, \mathrm{P}<0,05$ em comparação com camundongos não infectados (0) ou controle não estimulado. Ag, antígeno. 
utilizados como grupo controle, foram infectados iv com $1 \times 10^{7}$ parasitos em fase estacionária de crescimento e a carga parasitária foi acompanhada até 8 semanas após a infecção. Como mostrado na Figura 7A, os camundongos knockouts foram mais suscetíveis à infecção em todos os tempos observados, exibindo quantidades significativamente maiores de parasitos em ambos baço e fígado, quando comparado aos animais WT. De maneira interessante, foi observado que camundongos deficientes da citocina IL-6 e da subunidade IL23p19 também tiveram um aumento significativo no número de parasitos (Figuras 7B e C), enquanto que os animais IL-22-/- não apresentaram diferenças significativas na carga parasitária (Figura 7D). As diferenças na carga parasitária observada entre os animais selvagens e os knockouts para IL-17R, IL6 e IL-23p19 sugerem que o perfil Th17 está envolvido com a resposta imune protetora contra a infecção por L. infantum/chagasi. O fato da citocina IL-22 está envolvida principalmente com a resposta imune em regiões de mucosa pode justificar o fato dessa citocina não ser relevante durante a infecção por $L$. infantum/chagasi, que atinge o baço, o fígado e a medula óssea, principalmente. 
A

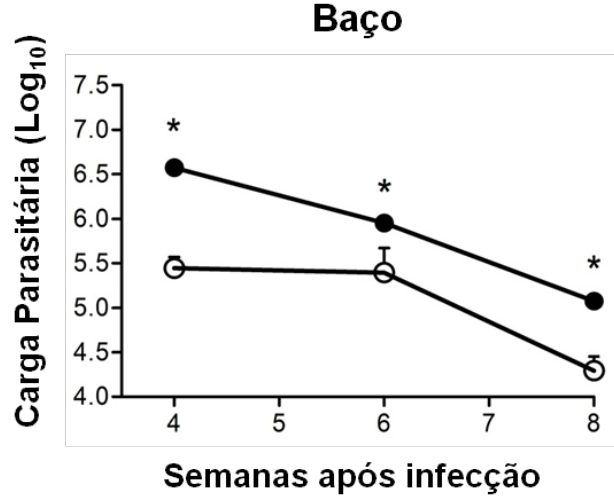

$\mathrm{B}$

C
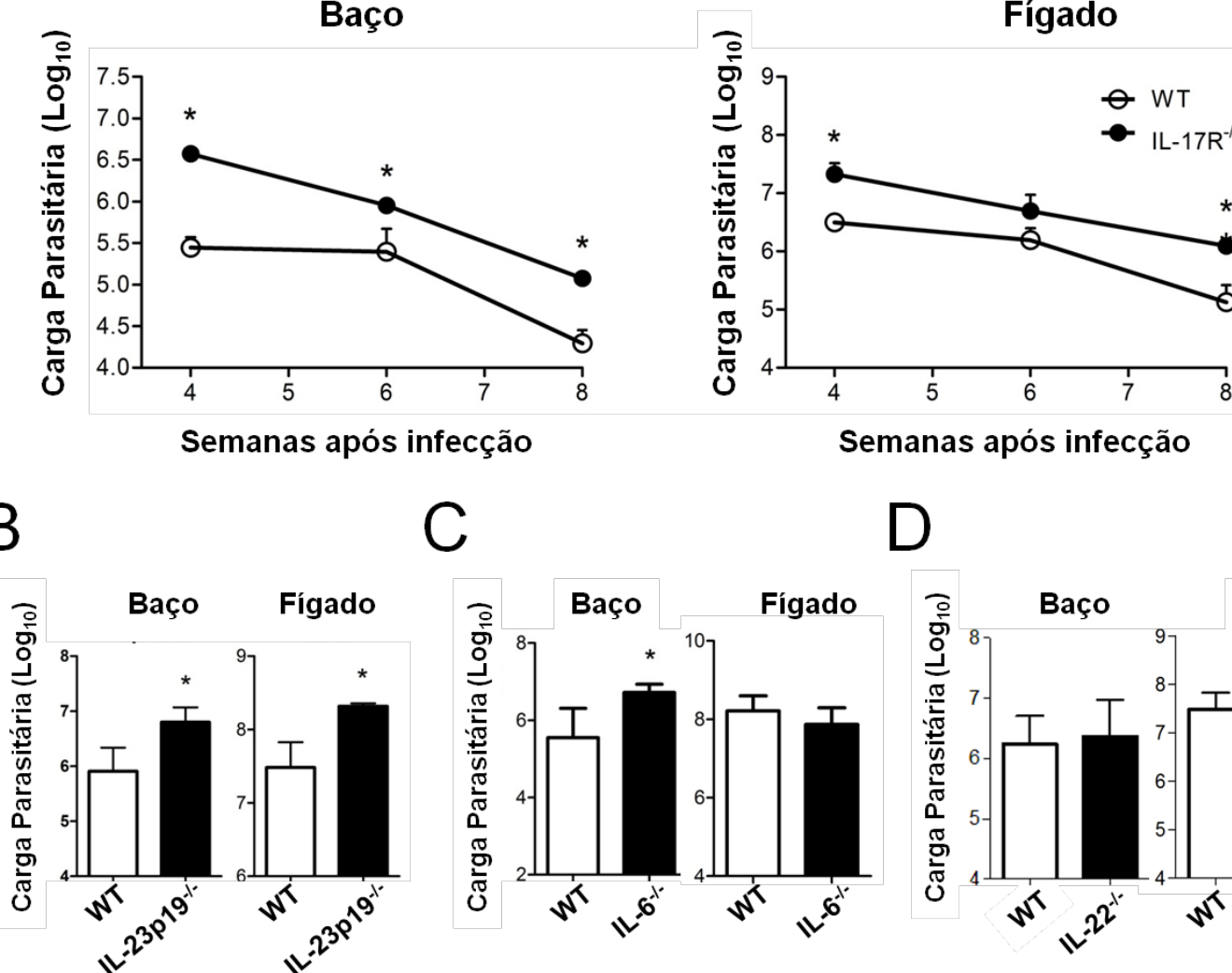

D
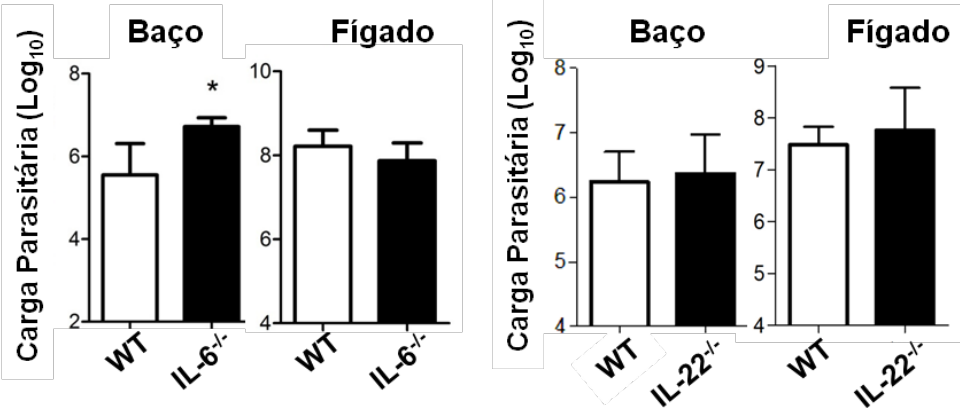

Figura 7: Os linfócitos Th17 participam no controle da infecção por L. infantum/chagasi. Camundongos WT, IL-17R $/$, , IL-23p19-/, IL-6 ${ }^{-/-}$e IL-22 $\%$ foram infectados iv com $1 \times 10^{7}$ parasitos em fase estacionária de crescimento para o estudo da carga parasitária. (A) O baços e o fígado dos animais WT (círculos abertos) e IL-17R /- (círculos fechados) foram coletados nos tempos indicados e a carga parasitária foi determinada pelo ensaio por diluição limitante. (B, C e D) Após 4 semanas de infecção animais WT (barras brancas), IL-23p19-/, IL-6/- e IL-22 (barras pretas) foram sacrificados para determinação da carga parasitária no baço e fígado, como descrito anteriormente. Os resultados são representativos de três experimentos independentes realizados em quadruplicata e estão expressos como a média \pm DP. * ${ }^{*} \mathrm{P}<0,05$ comparado ao grupo C57BL/6 WT controle infectado. 


\section{3) A citocina IL-17 é fundamental para o processo inflamatório} hepático durante a infecção por L. infantum/chagasi

Já é bem estabelecido na literatura que durante a infecção experimental em camundongos C57BL/6 o desenvolvimento de uma inflamação hepática com consequente formação de granulomas está associado ao controle do parasitismo nesse órgão (KAYE; SCOTT, 2011). Dessa forma, a fim de determinar os fatores envolvidos com a susceptibilidade dos camundongos IL17R $/$ - nosso próximo passo foi avaliar a cinética do processo inflamatório no fígado. Para isso, foram feitos cortes histológicos, corados com H \& E, do tecido hepático de animais WT e IL-17R/- não infectados e animais WT e IL-17R-/após 2, 4 e 6 semanas de infecção. Após duas semanas de infecção, é possível observar o início do processo inflamatório em ambos os grupos de animais (WT e IL-17R-/-), o qual continua a ser amplificado quando decorridas 4 e 6 semanas de infecção (Figura 8A). Na $6^{\mathrm{a}}$ semana, nota-se no fígado do camundongo WT uma infiltração leucocitária difusa, com concentração de células mononucleares em torno dos espaços porta, predominantemente. Além disso, no animal selvagem é possível perceber muitos hepatócitos claramente degenerados, e há alguns pontos de necrose, ampliando o dano hepático. Diferentemente da infiltração difusa observada no WT, o animal IL-17R-/- apresenta áreas inflamadas em menor tamanho, e, embora menores, os granulomas são 
aparentemente mais compactos, organizados e com presença de células gigantes (Figuras 8A e B). Assim, podemos inferir que na ausência da sinalização por IL-17 há uma diminuição da área inflamada ou lesionada no fígado, pois, enquanto que no WT algumas lesões (áreas de infiltração linfocítica) são maiores do que $150.000 \mu \mathrm{m}^{2}$, no IL-17R -/- a maior lesão mede $25.000 \mathrm{~mm}^{2}$ (Figura 8C). Confirmando esses dados, o nível sérico da transaminase hepática glutâmico-oxalacética (TGO) foi significativamente maior nos animais WT após 6 semanas de infecção, o que reflete um maior dano hepático em decorrência da inflamação no fígado desses animais (Figura 8D). Apesar do fato de os camundongos IL-17R $/$ - possuírem mais parasitos nos órgãos alvos, esses órgãos apresentam um menor peso quando comparados com os órgãos dos animais WT infectados sob as mesmas condições, e, além disso, os órgãos dos animais knockouts tendem a permanecer do mesmo tamanho durante o decorrer da infecção, enquanto que o baço e o fígado dos camundongos WT crescem de maneira contínua e significativa ao longo das semanas (Figuras 9A e B). Esse dado pode ser explicado em decorrência do infiltrado inflamatório expressivamente menor encontrado nos animais knockouts, que, por sua vez, está associado com a diminuição da capacidade desses animais em eliminar o parasito. Os resultados que apontam uma menor inflamação na ausência de sinalização via IL-17R é um dado esperado e consistente, visto que a IL-17 é uma citocina sabidamente relacionada com a 
Resultados

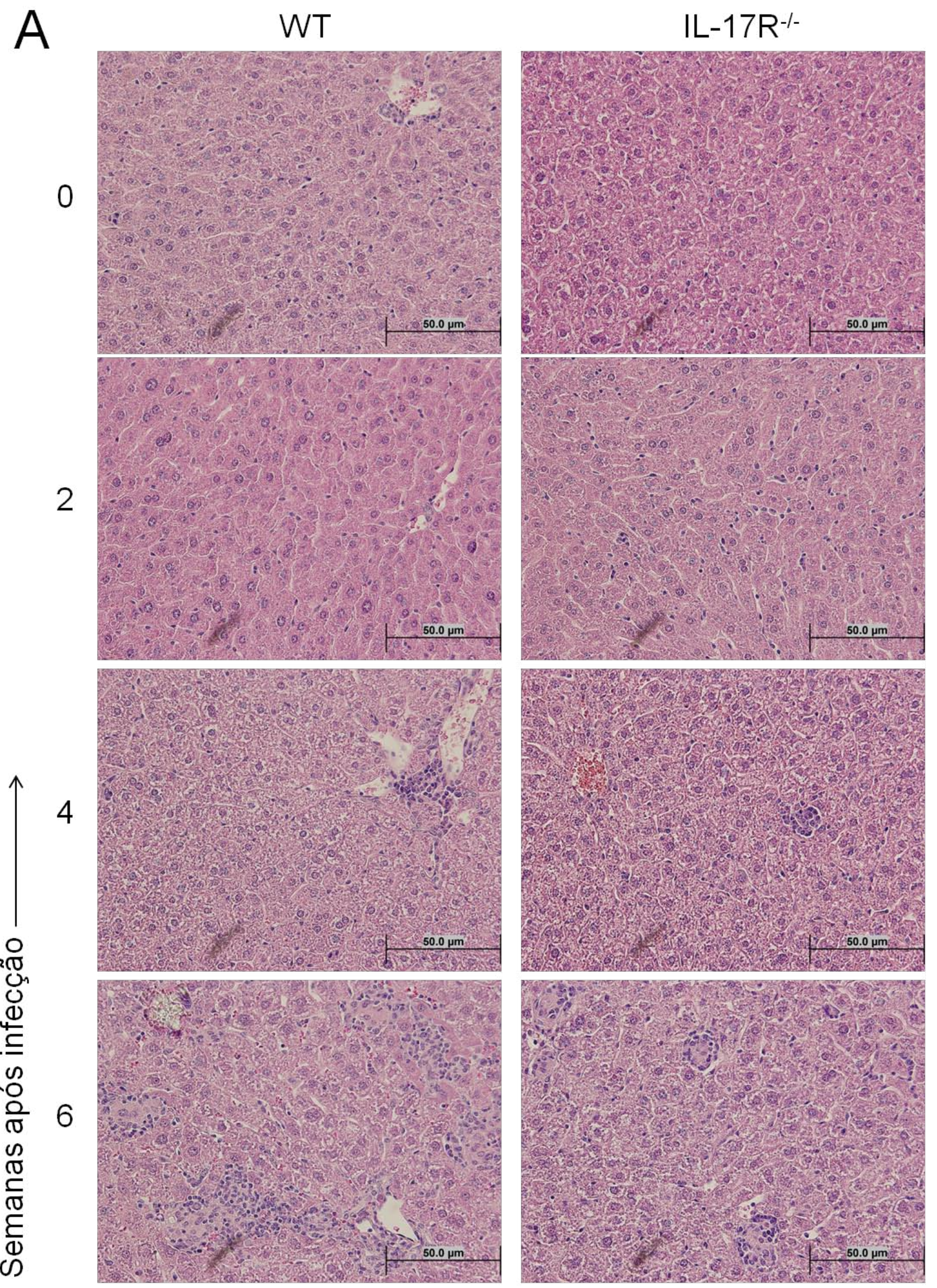


Resultados

B

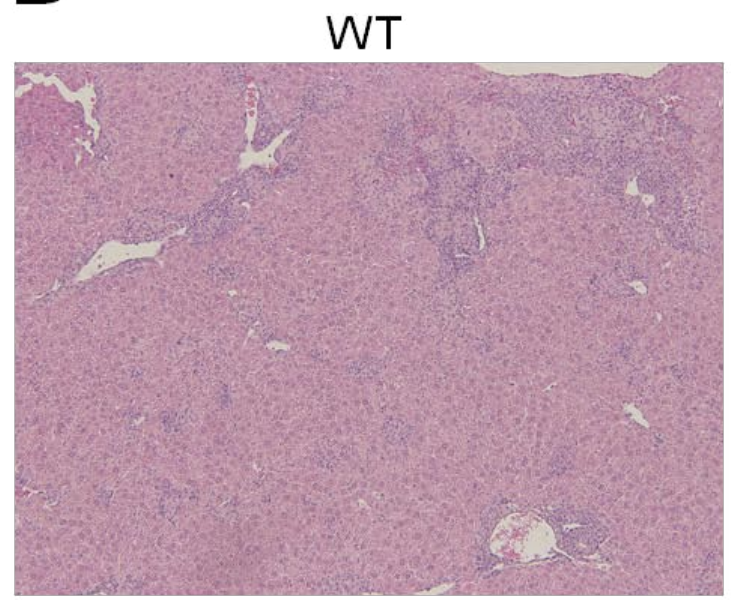

IL-17R-/-

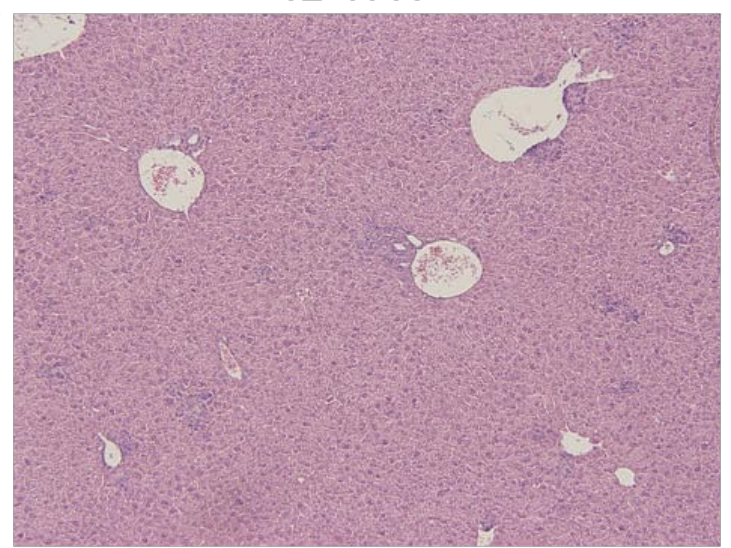

6 semanas após infecção

0

$4^{\mathrm{a}}$ semana após infecção

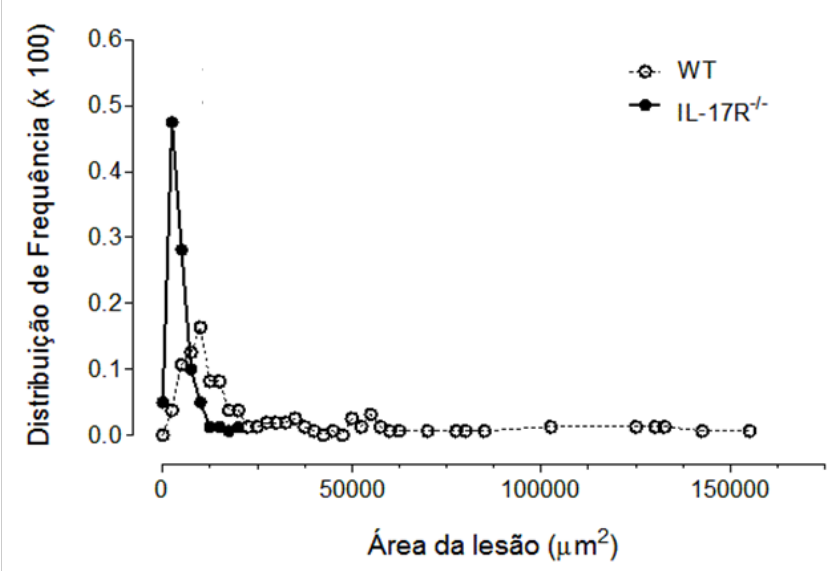

$6^{\mathrm{a}}$ semana após infecção

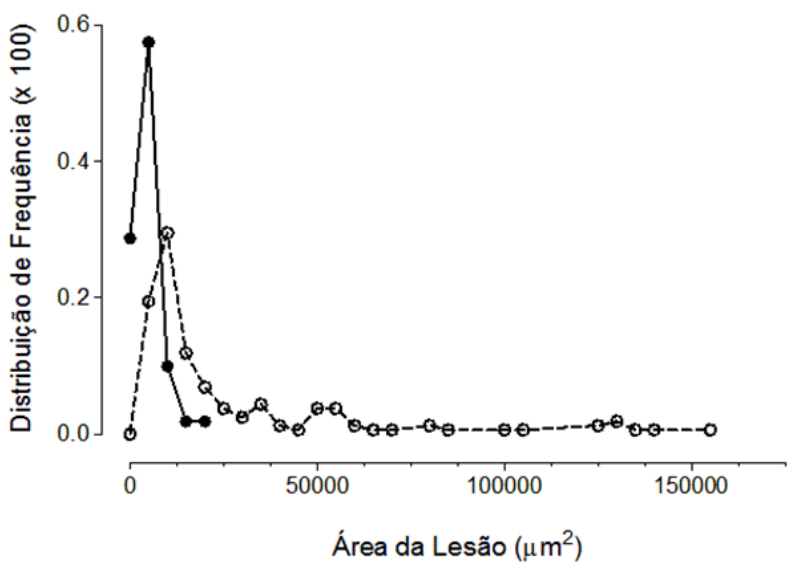

D

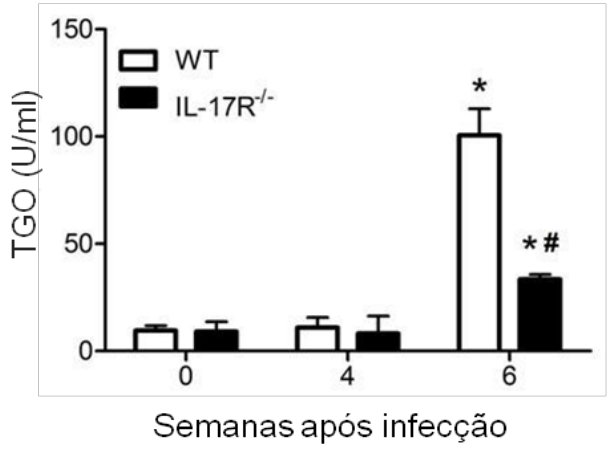


Figura 8: A citocina IL-17 contribui para o processo inflamatório hepático induzido por $L$. infantum/chagasi. Animais WT e IL-17R $/$ - durante a $2^{\mathrm{a}}$, $4^{\mathrm{a}}$ e $6^{\mathrm{a}}$ semanas de infecção, e controles não infectados, tiveram o tecido hepático e o sangue coletados para análises patológicas. (A) Fotomicroscopia do tecido hepático de animais WT e IL-17R-/- corado com H \& E em aumento de 400X. (B) Corte histológico do tecido hepático de camundongos WT e IL-17R-/- após 6 semanas de infecção em aumento de 100X. (C)A área inflamada ou lesionada foi medida nos animais WT (círculos abertos) e IL-17R-/- (círculos fechados) após 4 e 6 semanas de infecção com auxílio do programa Leica QWin - Quantitative Imaging. (D) $\mathrm{O}$ dano tecidual foi confirmado pelos níveis séricos de TGO nos animais WT e IL-17R-- após 4 e 6 semanas de infecção. Os resultados são representativos de dois experimentos independentes $(N=5)$ e são expressos como a média \pm DP. * $\mathrm{P}<0,05$ comparado ao grupo controle não infectado. \# $\mathrm{P}<0,05$ em relação ao WT durante a $6^{\text {a }}$ semana após a infecção. TGO, trasaminase glutâmico-oxalacética.

promoção da inflamação. Nós testamos a capacidade linfoproliferativa na ausência da sinalização da citocina IL-17 para descobrir se a diminuição da área de infiltração de linfócitos nos animais knockouts seria em decorrência da sua deficiente proliferação. De maneira curiosa, nossos achados mostraram que os linfócitos dos animais IL-17R /- apresentaram uma significativa redução de $61,59 \%$ para $11,14 \%$ na capacidade de proliferação quando comparados com os linfócitos dos animais WT estimulados com conA (Figura 9C), o que justifica as condições observadas de inflamação, carga parasitária, peso e tamanho dos órgãos nos animais deficientes do IL-17R. 

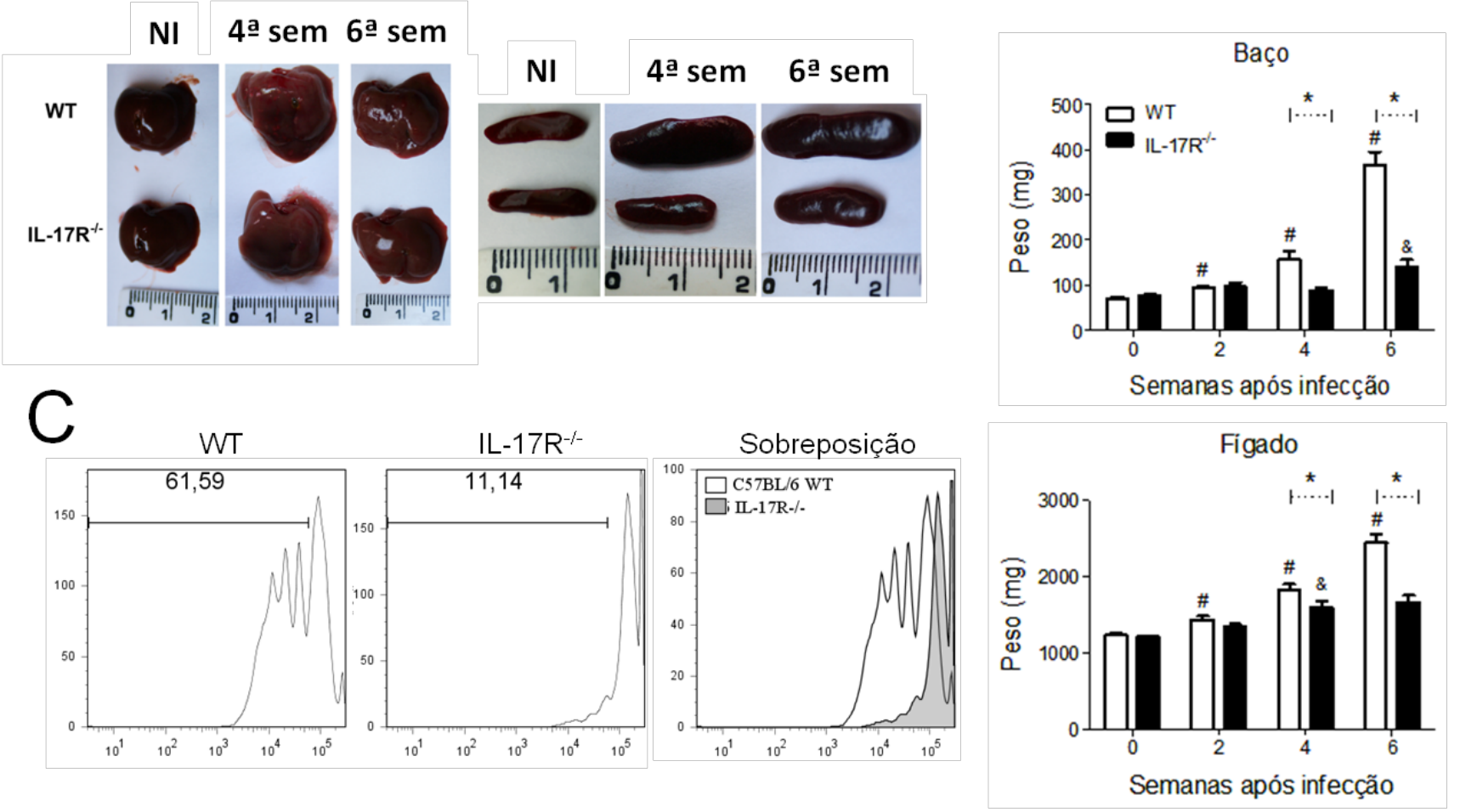

Figura 9: A sinalização da citocina IL-17 é importante para manutenção da capacidade proliferativa de linfócitos e consequente crescimento dos órgãos afetados pelo parasito. (A e B) Hepatoesplenomegalia nos camundongos WT e IL-17R-/- após 2, 4 e 6 semanas de infecção e em controles não infectados. (C) Células do baço de camundongos C57BL/6 e IL-17R-1- foram analisadas quanto a capacidade de proliferação através da técnica de diluição de CFSE sob estímulo com conA $(20 \mu \mathrm{g} / \mathrm{mL})$ por $96 \mathrm{~h}$. Os histogramas são representantivos de um único experimento $(\mathrm{N}=5)$. Os resultados estão expressos como a média \pm DP. ${ }^{*}, \mathrm{P}<0,05$ comparado ao grupo WT controle de cada semana. \#, $\mathrm{P}<0,05$ comparado com os animais do mesmo grupo. $\&, \mathrm{P}<0,05$ comparado com os animais do mesmo grupo do ponto imediatamente antes. sem, semanas após a infecção. 
Levando em consideração que a inflamação dos camundongos IL-17R-/não foi semelhante àquela observada em camundongos WT e, ao contrário dos camundongos do tipo selvagem, os knockouts falharam em conter o crescimento dos parasitos, o próximo parâmetro questionado foi quanto a produção de citocinas induzidas nesses grupos de camundongos. Para isso, realizamos uma citometria de fluxo dos linfócitos infiltrantes no fígado e baço dos animais IL17R-/- e WT após 4 semanas de infecção, durante o pico do parasitismo. Os animais deficientes do IL-17R tiveram uma expressão significativamente mais alta de IL-10 por linfócitos ativados, passando de 0,24\% de células CD3+IL-10+ no baço dos animais WT para $0,71 \%$ dessas células no baço dos animais IL-17R-/- (Figura 10). No fígado, a quantidade de linfócitos produtores de IL-10 passou de 0,20\% nos animais WT para 0,69\% nos animais knockouts (Figura 10), sugerindo que a regulação positiva dessa citocina supressora pode estar relacionada com a maior suscetibilidade dos animais IL-17R-/- e também com a deficiência na proliferação dos linfócitos knockouts. Além disso, foi observado um aumento significativo de células IFN- $\gamma^{+}$no baço (de $0,12 \%$ nos animais WT

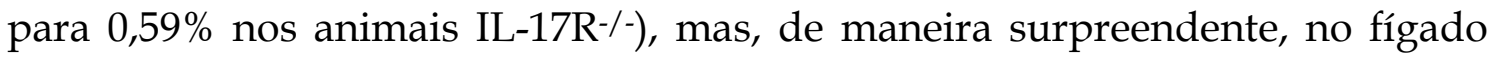
não houve diferença na produção dessa citocina entre os animais WT e IL-17R-/(Figura 10). Esse dado suporta a teoria de que há outro fator, além do IFN- $\gamma$, envolvido com a resistência do hospedeiro, visto que, mesmo em situações em que ocorre uma regulação positiva ou quando os níveis de IFN-ץ não são 
alterados nos animais IL-17R-/- comparados com o WT, a carga de parasitos no knockout é maior. Juntos, esses resultados demonstram que, ao contrário dos

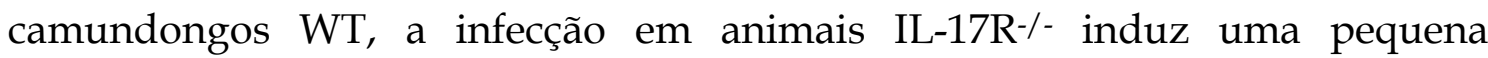
infiltração inflamatória hepática em decorrência de uma capacidade linfoproliferativa prejudicada e, além disso, resulta na geração de uma resposta com efeito anti-inflamatório ou regulador, dominada por IL-10, resultando em uma deficiência em controlar o crescimento do parasito. Além disso, outra observação importante é que a citocina IL-17 é um fator crucial na eliminação do parasito do fígado, podendo esse papel ser desempenhado através do auxílio ao efeito do IFN- $\gamma$, citocina pró-inflamatória sabidamente produzida em altas quantidades durante infecções por L. infantum/chagasi e crítica para indução de moléculas leishmanicidas por macrófagos infectados.

\section{4) IL-10 regula negativamente os níveis de IL-17 induzidos pela $L$.}

\section{infantum/chagasi}

Como já demonstrado em vários trabalhos, a polarização de um subconjunto celular específico inibe a diferenciação de outros perfis através da liberação de citocinas características. Como observado antes, a IL-17 é capaz de regular os níveis de IL-10, e, por esse motivo, nos testamos a hipótese de que o contrário poderia acontecer. Para isso, camundongos WT e IL-10-/- foram 


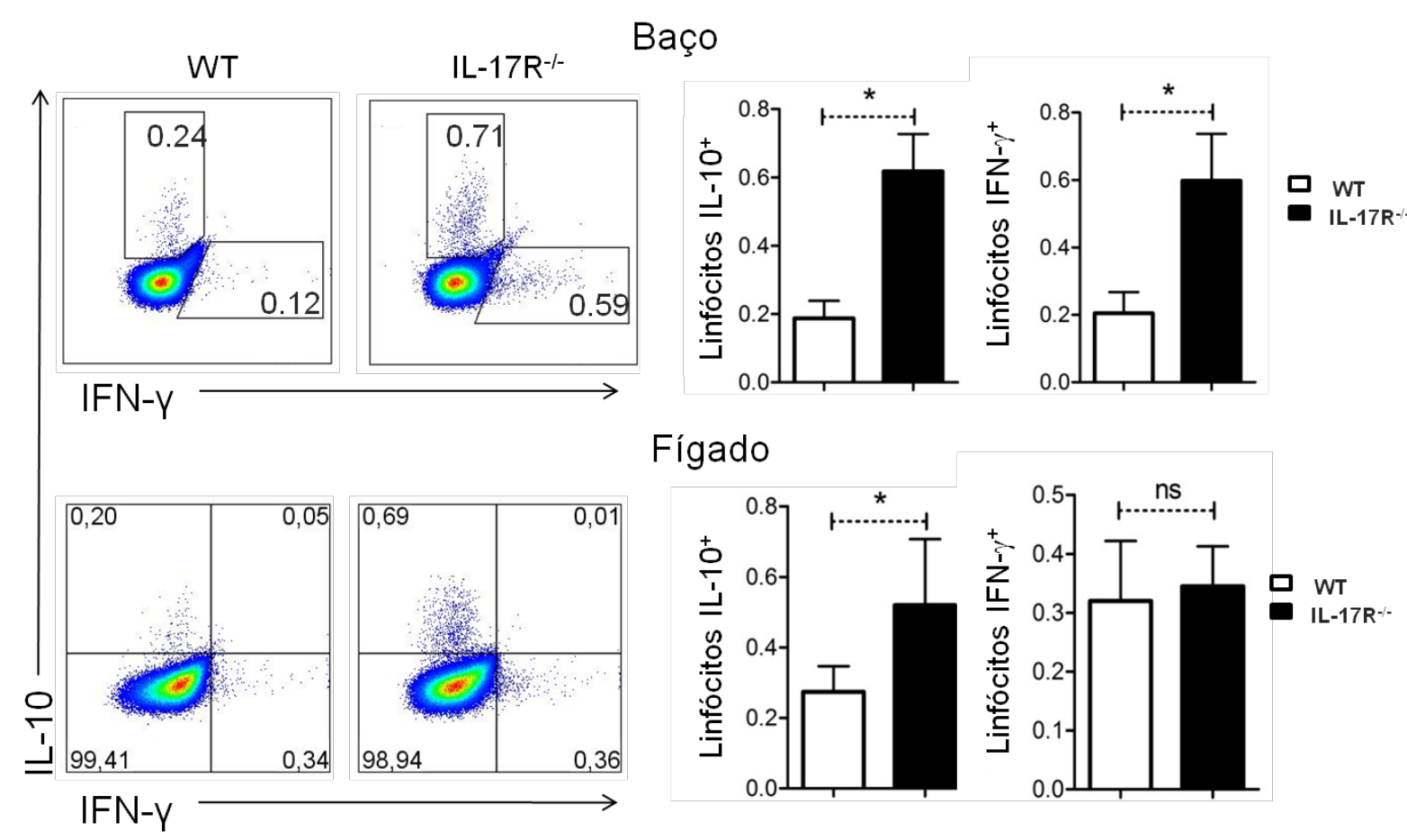

Figura 10: A citocina IL-17 regula negativamente a produção de IL-10 por linfócitos. Animais IL-17R-/- e WT foram infectados iv com $1 \times 10^{7}$ parasitos em fase estacionária de crescimento. O baço e o fígado dos animais foram coletados após 4 semanas de infecção e as células foram marcadas com anticorpos monoclonais específicos conjugados a fluorocromos distintos. A análise das células IL-10+ $0^{+}$IFN- $\gamma^{+}$foram feitas dentro da população de células CD3 $^{+}$e determinada por citometria de fluxo. Os dot-plots exibem o resultado representativo dos gráficos de barra de dois experimentos independentes. Os resultados são expressos como a média \pm DP. *, P <0,05 comparado ao grupo controle C57BL/6 WT infectado.

infectados para análise da modulação do perfil de citocinas induzidas na ausência de IL-10 no baço, que é um órgão sistêmico. As células do baço de animais IL-10-/- e controles WT, após 4 semanas de infecção, foram cultivadas na presença ou ausência do estímulo com antígeno bruto de L. infantum/chagasi 
por 72 h, quando então as células foram colhidas para análise por citometria de fluxo e o sobrenadante foi coletado para ensaio de ELISA. De fato, após a infecção, a ausência de IL-10 acarretou em um aumento no número de células produtoras de IL-17. Esse aumento foi de 0,35\% no WT para 0,57\% no IL-10-/em células cultivadas na ausência de estímulo, e de $0,62 \%$ no WT para 0,85\% no IL-10/- em culturas reestimuladas com antígeno de L. infantum/chagasi por 3 dias (Figuras 11A e B). O aumento na produção da citocina IL-17 nos animais IL-10/-- também foi confirmado através do ELISA do sobrenadante das culturas de baço, onde foi observado um aumento significativo de 3 vezes na quantidade de IL-17 produzida por células dos animais IL-10/- reestimuladas com antígeno de L. infantum/chagasi (Figura 11C). Ademais, como esperado, na ausência de IL-10 houve um aumento significativo nas células produtoras de IFN-ץ (Figuras 11A e B). Além das análises de produção de citocina, nós realizamos a carga parasitária, e, como esperado, os animais IL-10/- mostraram menores quantidades de parasitos em ambos baço e fígado (Figura 11D). A resistência observada nos camundongos IL-10-/- pode ser atribuída não apenas à ausência

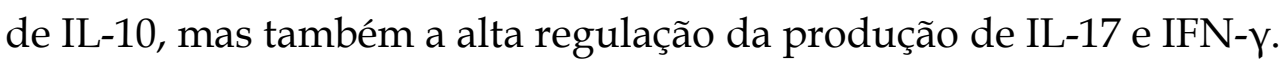


A

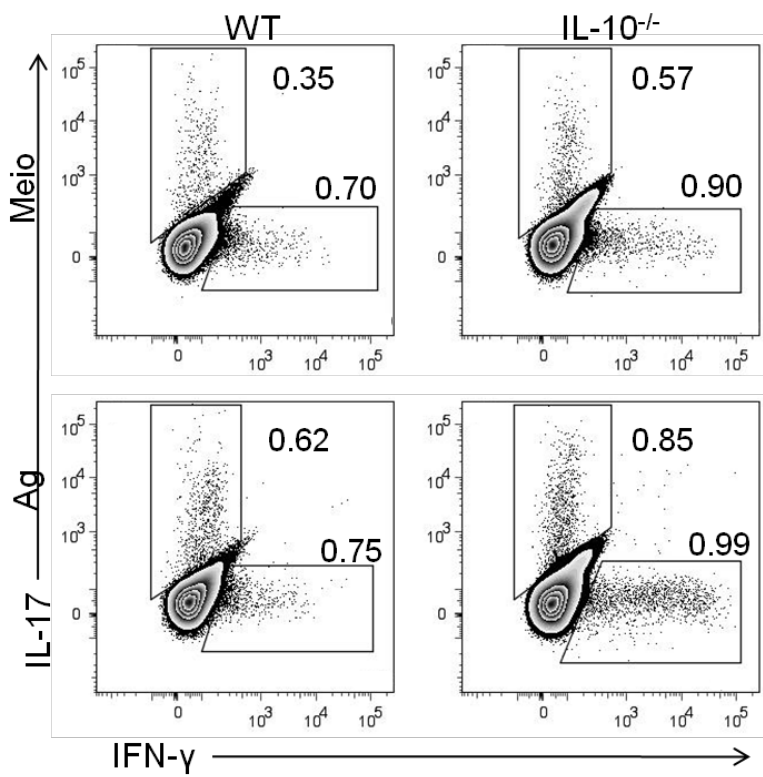

B
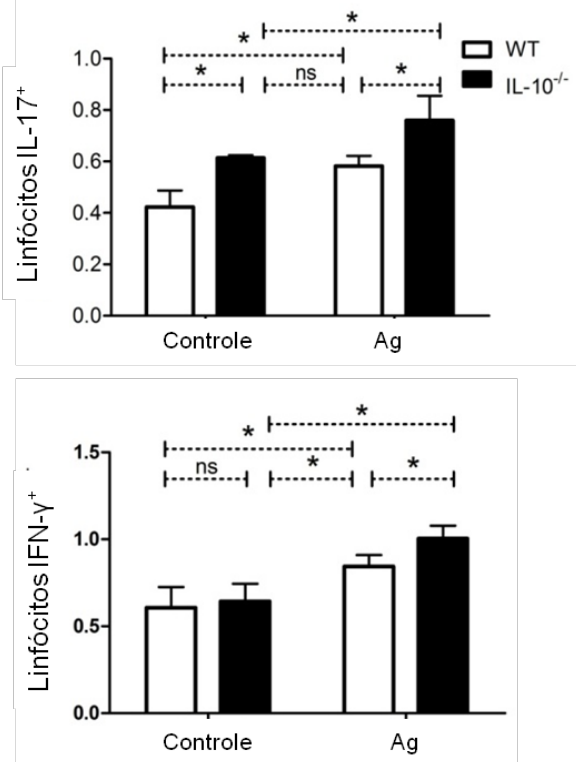

Baço

Fígado
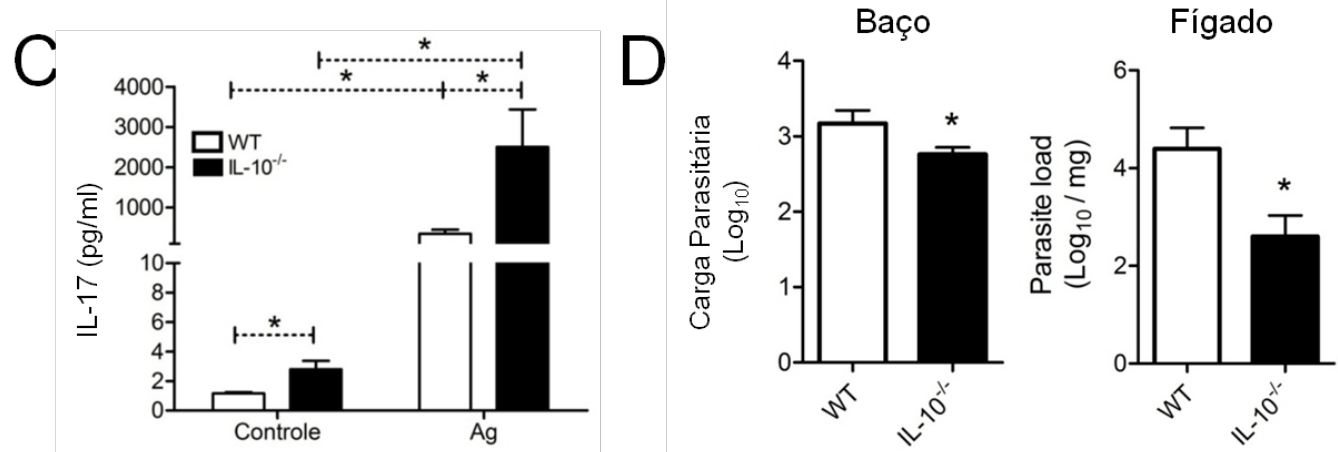

Figura 11: IL-10 regula negativamente a produção de IL-17. Camundongos IL-10/- e WT foram infectados iv com $1 \times 10^{7}$ parasitos em fase estacionária de crescimento. $\mathrm{O}$ baço e o fígado foram coletados após 4 semanas de infecção e as células foram restimuladas com antígeno bruto de L. Infantum/chagasi $(50 \mu \mathrm{g} / \mathrm{ml})$. Três dias depois, as células foram coletadas para análise por citometria de fluxo e o sobrenadante foi coletado para quantificação de citocinas por ELISA. (A) Os dot-plots mostram a análise das células IL- $17^{+}$e IFN- $\gamma^{+}$realizada dentro da população CD3+ determinada por citometria de fluxo, e exibem resultados representativos dos gráficos de barras mostrados em B. (C) O ELISA foi realizado no sobrenadante da cultura de células do baço e (D) a carga parasitária foi determinada pelo ensaio de diluição limitante 4 semanas após a infecção. Os resultados são representativos de dois experimentos independentes e são expressos como a média \pm DP. *, P <0,05, em comparação ao grupo controle infectado C57BL/6 WT. ns, não significativo. Ag, antígeno 


\section{5) IL-17 tem papel importante para promover aumento da secreção de} óxido nítrico durante a infecção por L. infantum/chagasi

Macrófagos e demais fagócitos, como células dendríticas e neutrófilos, compõem o conjunto de células que são suscetíveis à infecção por parasitos do gênero Leishmania. Os macrófagos são as principais células responsáveis por matar esses parasitos, dado ao fato de que, uma vez infectados, macrófagos submetidos à estimulação com IFN-ץ passam a expressar a enzima iNOS, e isso acarreta a morte dos parasitos via a produção de NO. Em decorrência disso, os macrófagos desempenham um papel central na imunidade aos parasitos do gênero Leishmania (GANTT et al., 2001; STENGER et al., 1994). Estudos anteriores demonstram que a IL-17 também atua sobre as células dendríticas e macrófagos induzindo IL-12 e IFN-ץ (ISHIGAME et al., 2009; LIN et al., 2009), uma vez que essas células expressam IL-17R. Com base nisso, para entender o mecanismo pelo qual a IL-17 promove a proteção do hospedeiro contra a $L$. infantum/chagasi a nível celular, nós avaliamos o efeito da IL-17 em BMMФ infectados através da dosagem dos níveis de NO induzidos. Para isso, mensuramos a produção de NO por macrófagos após 48 h de infecção na presença ou ausência de diferentes doses de IFN-ץ (10 e 100 ng/ml) e/ou IL-17 (30, 100 e $300 \mathrm{ng} / \mathrm{ml})$ recombinantes. Sem citocinas exógenas, os níveis de NO secretados permaneceram baixos, no entanto, o pré-tratamento com ambas as 
concentrações de IFN- $\gamma$ testadas induziu grandes quantidades de $\mathrm{NO}, 25,36 \mu \mathrm{M}$ de nitrito quando o pré-tratamento foi com $10 \mathrm{ng} / \mathrm{mL}$ de IFN- $\gamma$ e 28,41 $\mu \mathrm{M}$ com o estímulo de 100 ng/mL de IFN-ץ (Figura 12A). A citocina IL-17, entretanto, induziu um aumento significativo na produção de NO somente quando altas concentrações da citocina foram usadas (100 e $300 \mathrm{ng} / \mathrm{mL}$ ) (Figura 12B). Curiosamente, quando os $\mathrm{BMM} \Phi$ s foram tratados com as duas citocinas combinadas, a IL-17 foi capaz de potencializar a produção de NO induzida pelo IFN- $\gamma$, de maneira dose-dependente, aumentando a produção de $28,41 \mu \mathrm{M}$ de nitrito quando o tratamento foi com $100 \mathrm{ng} / \mathrm{mL}$ de IFN- $\gamma$ para $48,41 \mu \mathrm{M}$

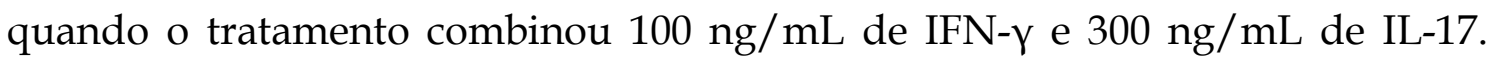
Este resultado indica que essas citocinas operam em sinergia para proporcionar aumento da produção de NO, molécula chave necessária para matar parasitos intracelulares como a L. infantum/chagasi.

Para verificar se a IL-17 exerceria um efeito biológico mensurável na indução de NO in vivo, nós analisamos a presença da enzima iNOS no fígado de camundongos WT e IL-17R-/- após 4 e 6 semanas de infecção, e em controles não infectados, através de imunofluorescência. Como mostrado na Figura 13, após 4 semanas de infecção no animal WT, pode-se perceber a expressão de iNOS em locais coincidentes ao processo inflamatório, e os hepatócitos que circundam a inflamação aparentemente não estão expressando a enzima, ao passo que aqueles localizados mais distantes das células inflamatórias 


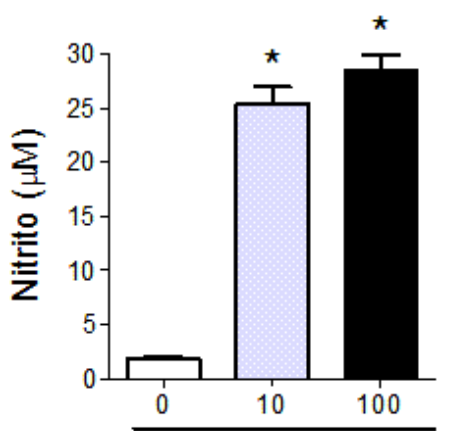

$\mathrm{IFN}-\gamma(\mathrm{ng} / \mathrm{mL})$

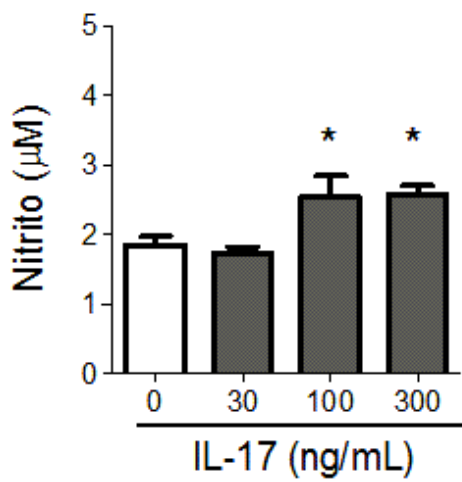

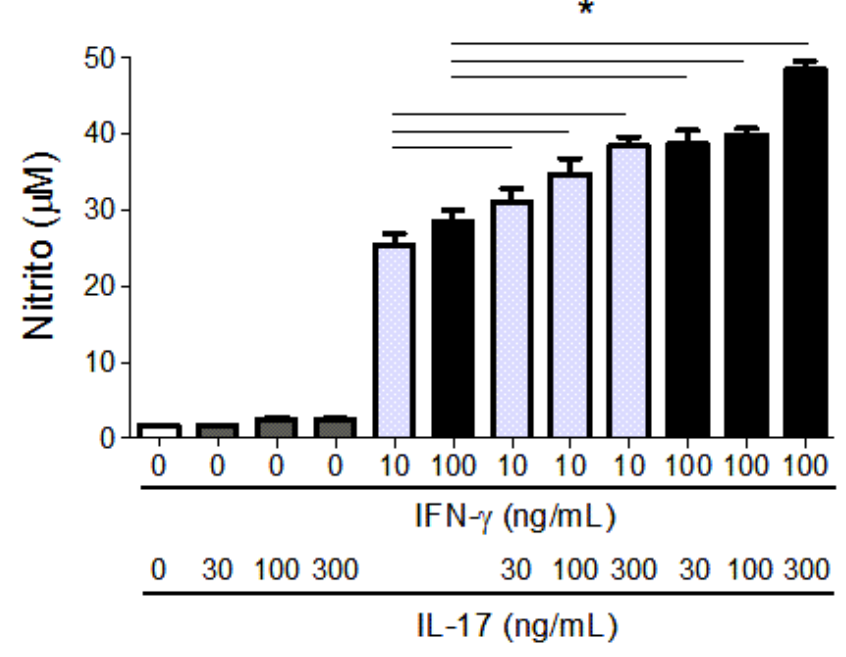

Figura 12: Efeito sinérgico da IL-17 e do IFN- $\gamma$ na potencialização da secreção de NO por macrófagos infectados. BMM $\phi$ s foram ativados com diferentes concentrações de (A) IFN- $\gamma(0$, 10 e $100 \mathrm{ng} / \mathrm{ml}$ ), mais (B e C) IL-17 (0, 30, 100 e $300 \mathrm{ng} / \mathrm{ml}$ ), seguido pela infecção das células com L. infantum/chagasi (MOI 5). A liberação de nitrito foi mensurada após $48 \mathrm{~h}$ de infecção através do método de Griess. Os resultados são representativos de um único experimento, e são expressos como a média \pm DP. ${ }^{*}, \mathrm{P}<0,05$, em comparação com grupo controle sem tratamento com citocinas exógenas.

expressam uma pequena quantidade de iNOS. Esse mesmo evento ocorre no animal WT após 6 semanas de infecção, sendo o processo mais expressivo em decorrência da exacerbação do processo inflamatório. No animal knockout 
também observamos uma expressão de iNOS por hepatócitos quando a inflamação ainda está pequena (após 4 semanas de infecção). Após 6 semanas de infecção no animal IL-17R-/- o aumento da inflamação leva um aumento da expressão de iNOS por células inflamatórias e uma diminuição da expressão pelos hepatócitos. Esse mecanismo apresentado em ambos os animais parece ocorrer devido um processo compensatório, de modo que, quando há menos inflamação há menos expressão de iNOS por células inflamatórias e mais por hepatócitos e a medida que a inflamação vai aumentando mais NO é produzido por células inflamatórias e menos por hepatócitos. Além disso, a expressão de iNOS e consequente produção de NO nos animais IL-17R-/- é um processo claramente mais discreto e retardado em comparação ao que ocorre com o animal WT. Portanto, de fato, foi constatado uma redução da expressão de iNOS no fígado do animal IL-17R-/- comparado com o selvagem, e isso traz consequências diretas na suscetibilidade dos animais IL-17R-/-. 
Resultados

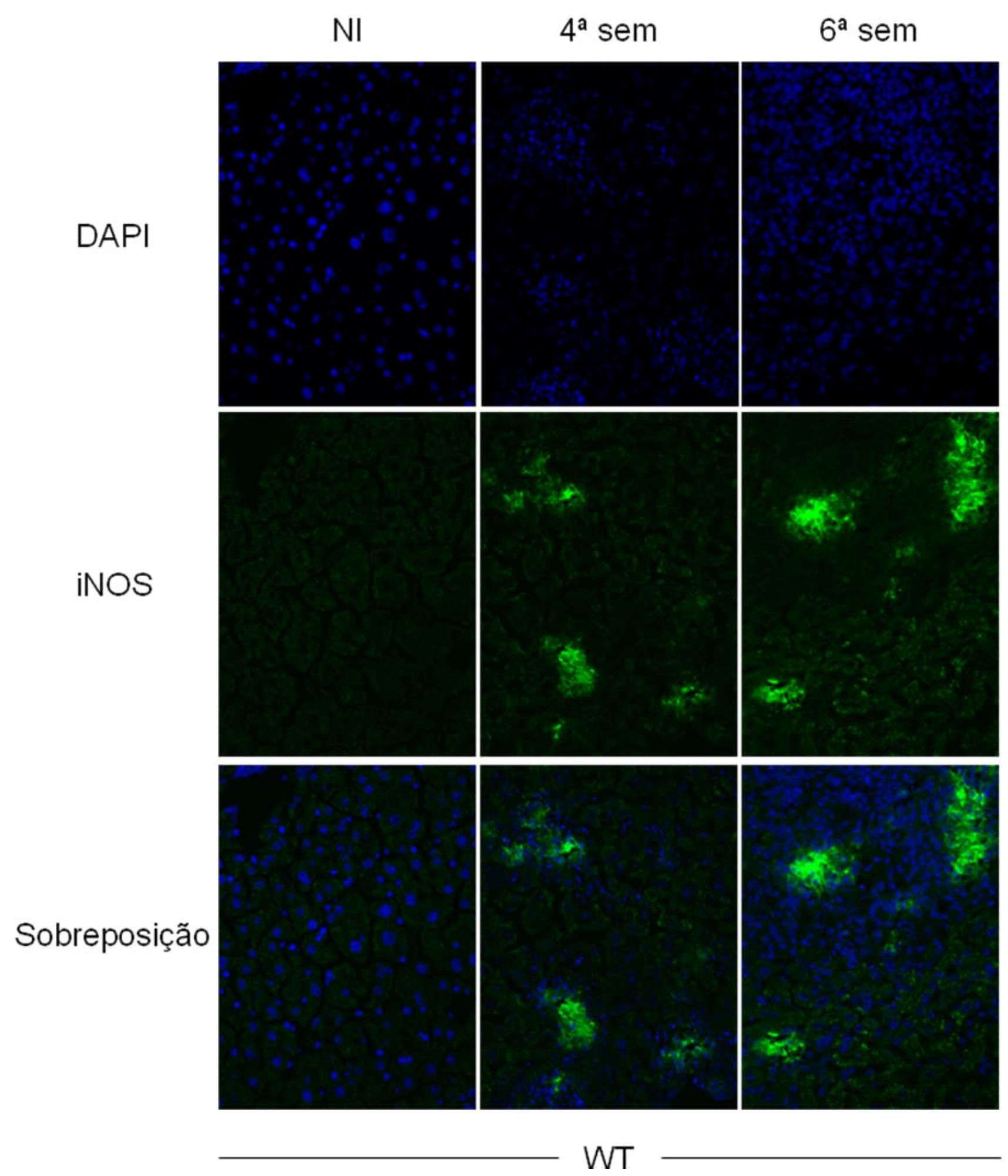




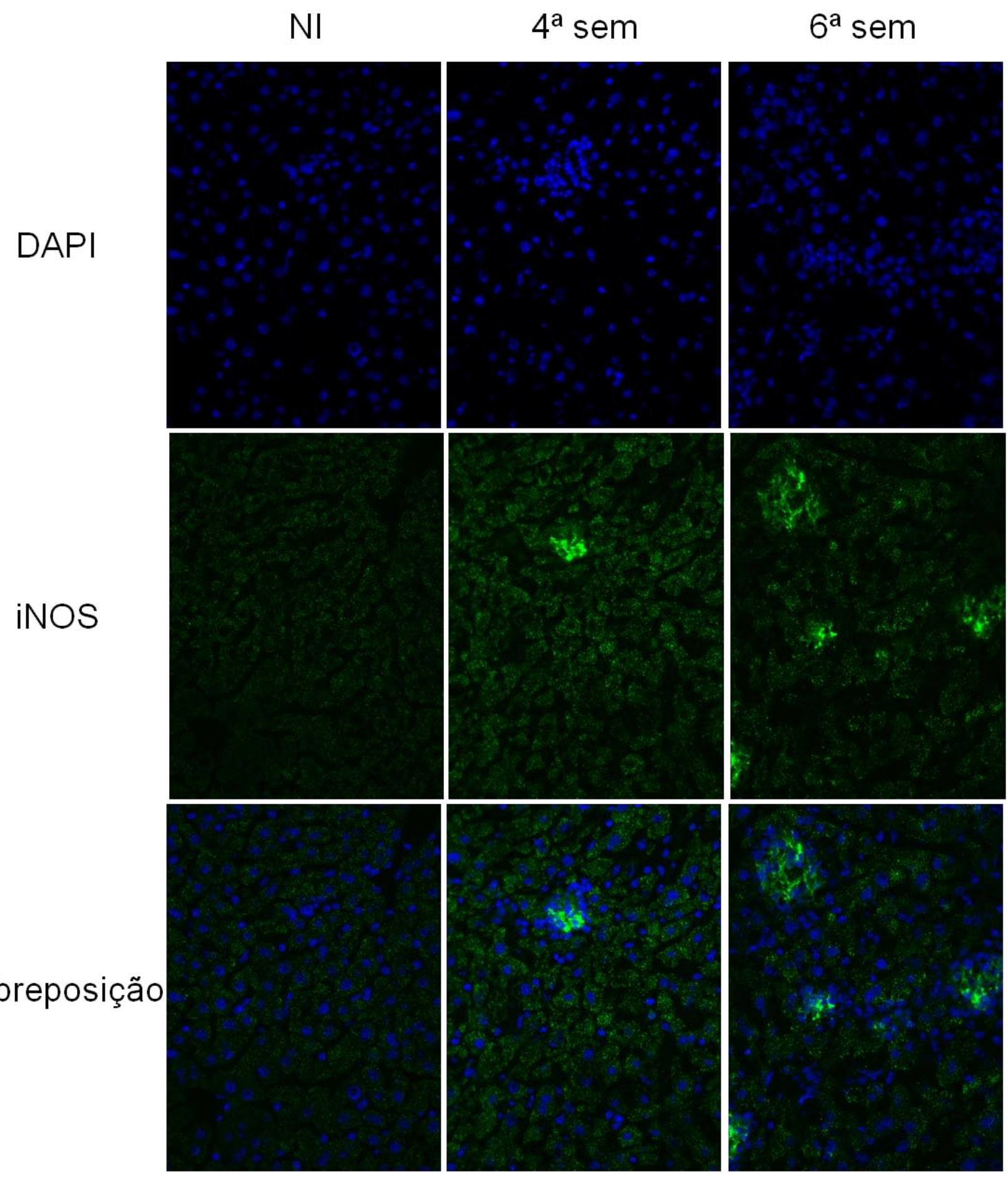

IL-17R $\mathrm{R}^{-/-}$ 
Resultados

Figura 13: A citocina IL-17 é essencial para a manutenção da expressão de iNOS durante a infecção. Camundongos WT e IL-17R /- foram infectados iv com $1 \times 10^{7}$ parasitos em fase estacionária de crescimento. O fígado foi coletado após 4 e 6 semanas de infecção e em controles não infectados. As marcações foram feitas com anticorpo específico para densidade nuclear, DAPI (mostrado em azul, $350 \mathrm{~nm}$ ) e para enzima iNOS conjugado com FITC (mostrado em verde, $488 \mathrm{~nm}$ ), e foram analisadas por imunofluorescência. As fotos representam capturas feitas em aumento de 400X. Os resultados são representativos de dois experimentos independentes. NI, não infectado. 
V) Discussão 
Durante uma infecção, a geração de uma resposta imunológica adequada é o ponto crucial que irá distinguir se o hospedeiro irá progredir para cura ou desenvolver a doença; ou ainda, no caso específico das leishmanioses, para um padrão assintomático da infecção. As células hospedeiras das espécies de protozoários do gênero Leishmania possuem um papel fundamental para promover o elo ideal entre a imunidade inata e adaptativa, e o grau de virulência do parasito poderá influenciar em três pontos cruciais da indução da resposta adaptativa adequada, a apresentação antigênica, a expressão de moléculas co-estimuladoras e a produção de citocinas. Nesse contexto, subconjuntos distintos de células $\mathrm{T} \mathrm{CD}^{+}$podem ser gerados a partir da estimulação por APCs infectadas. Já é bem consolidado que os parasitos do gênero Leishmania induzem um padrão de citocinas pró-inflamatórias relacionadas com o perfil Th1, como IL-12, TNF e IFN-ү, por macrófagos e outras células do sistema imunológico em hospedeiros resistentes (LIESE; SCHLEICHER; BOGDAN, 2008; WILSON; JERONIMO; PEARSON, 2005). Como descrito anteriormente, outro subconjunto pró-inflamatório conhecido por ter papel importante em algumas infecções intracelulares é o perfil Th17 (VAN, V et al., 2009). A diferenciação desse padrão efetor requer a presença das citocinas IL-1 $\beta$, TGF- $\beta$, IL-6 e IL-23 no microambiente inflamatório (VOLPE et al., 2008). Aqui, nós demonstramos que a infecção por L. infantum/chagasi induz a liberação desses fatores por células dendríticas e, durante a infecção in 
vivo a resposta imune adaptativa é eficientemente polarizada para o perfil Th17 efetor. Este mesmo evento pode ser observado durante infecções por outros Tripanosomatídeos, como T. cruzi (DA MATTA GUEDES et al., 2010; MIYAZAKI et al., 2010). A infecção por L. major também induz a produção de IL-23 por células dendríticas, sendo esse fato, entretanto, relacionado com a suscetibilidade do hospedeiro, uma vez que o desenvolvimento da lesão nesse modelo está associado com uma inflamação exacerbada (LOPEZ et al., 2009). Células dendríticas infectadas com L. donovani produzem IL-6, o que está associado com efeito protetor contra esse parasito através do controle da expansão de células CD25-FoxP3-IL-10+CD4+ (STAGER et al., 2006). Além disso, a L. donovani induz a produção de IL-17 por PBMCs humana (PITTA et al., 2009).

Embora a polarização do perfil Th17 inflamatório esteja relacionada com a patogênese de várias auto-imunidades e doenças inflamatórias crônicas, como encefalomielite, esclerose múltipla e sistêmica, psoríase, artrite reumatóide, lúpus eritematoso sistêmico (KURASAWA et al., 2000; LANGRISH et al., 2005; NAKAE et al., 2003a; WILSON et al., 2007; WONG et al., 2000), esquistossomose e LC por L. major (RUTITZKY; STADECKER, 2006a; LOPEZ et al., 2009), nossos resultados mostraram um papel crucial das células Th17 na imunidade a LV por L. infantum/chagasi, uma vez que a deficiência de IL-17R, IL-6 e IL-23p19 acarretou uma maior carga de parasitos nos órgãos-alvo da 
infecção, o baço e o fígado. Corroborando com nossos resultados, estudos anteriores também mostraram que o eixo de citocinas relacionadas com o padrão Th17 desempenha um papel protetor em várias doenças infecciosas, como por exemplo, mediando o controle da parasitemia em camundongos BALB/c e C57BL/6 infectados com Trypanosoma congolense (MOU et al., 2010); ajudando no controle sistêmico da infecção experimental por C. albincans (HUANG et al., 2004); atuando na proteção contra as infecções bacterianas por P. carinii (RUDNER et al., 2007) e M. tuberculosis (KHADER et al., 2007) ou contra os protozoários como T. gondii (LIEBERMAN et al., 2004) e T. cruzi (DA MATTA GUEDES et al., 2010), entre outros. Durante a infecção por L. braziliensis, agente causador da LC, a IL-17 produzida por células T também parece está relacionada com a proteção do hospedeiro infectado (VARGASINC; XIN; SOONG, 2008), e a ausência de IL-23 e IL-17, mas não de IL-22, resulta em um aumento de susceptibilidade à infecção pulmonar por Francisella tularensis (LIN et al., 2009). No nosso modelo, a ausência de IL-22 também não alterou a carga parasitária dos animais, ademais, em modelo de encefalomielite autoimune experimental foi demonstrado que, diferentemente da IL-17, a IL-22 não é requerida como fator pro-inflamatório relacionado com o desenvolvimento da doença e das lesões do tecido (KREYMBORG et al., 2007). Apesar dessas evidências, em 2009 foi relatado o papel protetor da resposta Th17 durante a LV por L. donovani em humanos, importância atribuída às 
citocinas IL-17 e IL-22 (PITTA et al., 2009). A IL-22 é uma citocina da família da IL-10, que participa principalmente da defesa do hospedeiro em ambientes de interface, como mucosas, vias aéreas, trato gastrointestinal e pele, mantendo a integridade das barreiras e trabalhando nos reparos (AUJLA et al., 2008; BONIFACE et al., 2005; WOLK et al., 2004; WOLK et al., 2006). Sua função pró ou antiinflamatória ainda é controversa, variando dependendo do modelo de estudo. No fígado, há estudos que indicam que seu efeito seja pró-inflamatório, contudo, isso ocorre em um modelo não infeccioso de hepatite (PAN et al., 2004; RADAEVA et al., 2004).

Uma característica peculiar da resposta imunológica contra Leishmanias visceralizantes é uma resposta imune órgão-específica. O desencadeamento de uma inflamação granulomatosa madura é dependente basicamente de um agente incitante e da situação da resposta imune do hospedeiro (ADAMS, 1974; SPECTOR; LYKKE, 1966). De maneira geral, durante uma infecção experimental por L. infantum/chagasi ou L. donovani a formação de granulomas hepáticos, mas não esplênicos, é iniciada entre a $4^{\mathrm{a}}$ e a $6^{\mathrm{a}}$ semanas, e isso está associado com o fim do crescimento da Leishmania e a resolução da infecção no fígado, enquanto que o parasito persiste cronicamente no baço (ENGWERDA; KAYE, 2000; WILSON; JERONIMO; PEARSON, 2005). Nossos resultados mostram que a infecção evoca uma infiltração inflamatória hepática progressiva em ambos IL-17R-/- e WT, mas, com uma acumulação leucocitária em 
proporções distintas. Diferentemente da infiltração difusa observada no WT, os camundongos knockouts mostraram uma inflamação contida em uma área significativamente menor, apresentando, portanto, uma menor lesão hepática. Mesmo assim os camundongos IL-17R /- foram capazes de formar pequenos granulomas maduros, mas que claramente não foram eficazes em eliminar o parasito. A formação de estruturas granulomatosas robustas, que é normalmente associada com o início da regressão do parasitismo no fígado, coincidiu exatamente com o declínio da carga parasitária nesse órgão em ambos os grupos de camundongos analisados, sendo mais eficiente nos animais WT. De fato, pacientes com LV progressiva não são capazes de desenvolver granulomas maduros (MURRAY, HW in GALLIN, JI, 1999). Realmente é esperado que a ausência da sinalização via IL-17 acarrete em uma inflamação diminuída no hospedeiro, uma vez que a citocina IL-17 é uma potente indutora de inflamação. Em modelos de infecção com ovos de Schistosoma já foi demonstrado que tanto a citocina IL-17 quanto IL-23 e IL-1 $\beta$ são potentes indutoras da inflamação granulomatosa hepática, com bastante infiltrado de neutrófilos e eosinófilos, relacionada com a patogênese nesse tecido (RUTITZKY; LOPES, JR.; STADECKER, 2005; RUTITZKY; STADECKER, 2006b; SHAINHEIT et al., 2008; WEN et al., 2011). Estudos com M. tuberculosis também demonstraram que a ausência da IL-17 leva uma redução no tamanho dos granulomas pulmonares em decorrência de uma deficiência em sua 
maturação (OKAMOTO et al., 2010; UMEMURA et al., 2007). Esse evento ocorreria porque a ausência da IL-17 diminui os níveis de expressão de ICAM-1 e LFA-1, diminuindo, consequentemente, a interação célula-célula, evento pelo qual justificaria o defeito na maturação dos granulomas pulmonares (OKAMOTO et al., 2010). Em nosso trabalho, a acumulação diferencial de leucócitos no foco inflamatório observado nos dois grupos de camundongos foi atribuída como consequência da redução da capacidade proliferativa dos linfócitos oriundos dos camundongos knockouts, que, por sua vez, pode ter ocorrido como consequência do efeito do excesso de IL-10 no microambiente. Existem poucos trabalhos que evidenciam o poder da IL-17 em induzir proliferação celular. O que se sabe é que células-tronco mesenquimais humanas e murinas expressam IL-17R, e a IL-17 é capaz de atuar nessas células induzindo proliferação através do aumento da fosforilação da MAPK p38 (HUANG et al., 2009; HUANG et al., 2006). Essas observações enquadram a citocina IL-17 como um fator de crescimento de células estromais. Os nossos resultados indicam, portanto, que a sinalização através do receptor da IL-17 em células do sistema imunológico é importante para a promoção da inflamação no fígado, a qual irá participar da eliminação do parasito. De fato, as células Th17 estão ligadas à exacerbação da inflamação através da indução de diversas citocinas inflamatórias e quimiocinas, porém, para nosso conhecimento, foi demonstrado pela primeira vez que a IL-17 também promove a inflamação em 
decorrência do aumento da capacidade de proliferação das células no órgão alvo da infecção, atuando como fator de crescimento celular. Em consequência disso, entretanto, os animais que expressam a IL-17 e o seu receptor apresentam maior crescimento dos órgãos afetados pelo parasito.

Já se sabe que a IL-10 atua em ambos os sistemas inato e adquirido regulando a resposta imunológica e minimizando a lesão tecidual (FIORENTINO; BOND; MOSMANN, 1989). Há muitos estudos que demonstram uma íntima relação entre a produção de IL-10 com a suscetibilidade do hospedeiro e a exacerbação da leishmaniose (ALEXANDER; BRYSON, 2005; ANDERSON et al., 2007a; AWASTHI; MATHUR; SAHA, 2004; BELKAID et al., 2001b; CARVALHO et al., 1989; GAUTAM et al., 2011; GHALIB et al., 1993; JANKOVIC et al., 2007; KANE; MOSSER, 2001; MENDEZ et al., 2004; MURPHY et al., 2001; MURRAY et al., 2002; NYLEN et al., 2007b; PADIGEL; ALEXANDER; FARRELL, 2003; SACKS; NOBEN-TRAUTH, 2002; WILSON; JERONIMO; PEARSON, 2005). Além disso, o papel regulador da IL10 influencia negativamente a capacidade proliferativa de linfócitos e, portanto, a IL-10 é considerada uma citocina reguladora (GAUTAM et al., 2011; GHALIB et al., 1993; NYLEN et al., 2007b). Assim, a regulação positiva de IL-10 nos animais IL-17R-/- infectados observada em nossos resultados é um componente determinante na diminuição da inflamação e da maior susceptibilidade dos camundongos knockouts. Estudos com L. major e outros agentes infecciosos 
mostram que a IL-10 também pode ser produzida por células Th1 polifuncionais, como um mecanismo de imunorregulação durante fortes reações inflamatórias (ANDERSON et al., 2007a; JANKOVIC et al., 2007). Dados da literatura mostram que a presença de TGF- $\beta$ e IL-6 leva a concomitante produção de IL-10 e a regulação positiva do fator de transcrição característico de células Th17, o RORyt, bem como da citocina IL-17, esse fato parece estar envolvido com a manutenção da homeostase, e sugere que ambas IL-17 e IL-10 são dependentes de TGF- $\beta$ e IL-6 (MCGEACHY et al., 2007; MCGEACHY; CUA, 2008). Por outro lado, a IL-23 não altera a freqüência de células IL-17+IL-10+ ou IL-17-IL-10+ (MCGEACHY et al., 2007). Aqui, nós fornecemos evidências experimentais que suportam a hipótese de que a IL-17 regula a IL-10, bem como IL-10 regula IL-17, visto que camundongos IL-17R-/infectados tem produção aumentada de IL-10, e os animais IL-10-/- infectados aumentam a expressão de IL-17. Esse achado também está envolvido com o fato de que a geração de um padrão produtor de IL-17 per si regula negativamente a geração de outros perfis, e o oposto também é verdadeiro. Zhang e colaboradores, em 2011, mostraram que a produção de IL-10 por células T suprime células Th17 e melhora os sintomas da encefalomielite autoimune experimental (ZHANG et al., 2011). Outra evidência de que ocorre uma influência mútua entre as citocinas IL-10 e IL-17 é que em pacientes com doença inflamatória de Crohn os níveis de IL-17 são negativamente associados com os 
de IL-10, e camundongos IL-10\%- possuem aumento sistêmico da resposta de perfil Th17, comparados com controles WT, em consequência da maior expressão de IL-1 $\beta$ por células dendríticas nesse modelo (WILKE et al., 2011).

O estudo sobre o mecanismo pelo qual a IL-17 promove proteção ao nível celular nos levou a investigar o papel dessa citocina nos macrófagos, uma vez que os parasitos do gênero Leishmania infectam e se replicam no interior dessas células, e são elas que possuem a capacidade de matar este protozoário intracelular. Uma importante molécula leishmanicida produzida pelos macrófagos é o óxido nítrico, gerado após a ativação com IFN-ү e TNF de macrófagos infectados (CUNHA et al., 1993; GANTT et al., 2001). Há alguns estudos que demonstram que as células mielóides, tais como células dendríticas e macrófagos expressam quantidades significativas de mRNA para IL-17R, e são, portanto, capazes de responder a estímulos por IL-17 com o aumento da produção de IL-12 e IFN- $\gamma$, levando a morte de patógenos intracelulares (ISHIGAME et al., 2009; LIN et al., 2009). Como demonstrado neste estudo, a IL-17 induziu um significativo aumento na produção de NO por macrófagos infectados, e também foi capaz de aumentar os níveis de NO induzidos por IFN- $\gamma$, indicando que ambas as citocinas agem sinergicamente para desencadear o mecanismo mais importante para matar a Leishmania dentro dos fagolisossomos dos macrófagos. De fato, estudos anteriores já mostraram que a IL-17 aumenta os níveis de NO e expressão de iNOS em queratinócitos 
humanos (YANG et al., 2011), além de aumentar a expressão da enzima óxido nítrico sintase endotelial (eNOS) e de NO por células endoteliais humanas (LIU et al., 2012). Nossos resultados da imunofluorescência para análise de iNOS no tecido hepático corroborou com o dado obtido in vitro, uma vez que camundongos IL-17R -/- tiveram uma menor expressão de iNOS quando comparados com animais WT, confirmando a importância da IL-17 na indução da expressão de iNOS, . Curiosamente em locais menos inflamados há uma alta indução da expressão de iNOS por hepatócitos, enquanto que quando a inflamação se exacerba essa expressão dimunui nas células do fígado. Esse mesmo evento é observado em cardiomiócitos (OHTANI et al., 2011) em modelos de infecção que atingem o coração, como uma maneira de proteger as células do tecido onde a infecção e a inflamação estão instauradas. Além disso, após infarto do miocárdio observa-se uma regulação positiva da expressão das citocinas pró-inflamatórias IL-17A, IL-17F e do receptor IL-17R, e consequente aumento da expressão de iNOS pelas células do coração (BARRY et al., 2011). Analisados em conjunto, nossos dados demonstram que a $L$. infantum/chagasi induz a resposta Th17, a qual está relacionada com a regulação negativa da produção de IL-10 por linfócitos ativados, aumento da capacidade linfoproliferativa e potencialização da produção de NO. Com base nos resultados aqui apresentados, podemos concluir que o perfil Th17 tem um papel protetor durante a infecção por L. infantum/chagasi. Os estudos que 
Discussão

auxiliam a compreensão dos mecanismos complexos pelos quais a $L$. infantum/chagasi interage com as defesas do hospedeiro podem abrir novas perspectivas para o tratamento e profilaxia da LV, doença em franca expansão no território urbano brasileiro. 
VI) Conclusão 
Conclusão

A Leishmania infantum/chagasi dirige a resposta imune adaptativa para o padrão Th17 de resposta, o qual tem um papel protetor durante leishmaniose visceral. Os mecanismos efetores das células Th17 envolvidos com a resistência do hospedeiro envolvem a modulação negativa da produção de IL-10 por linfócitos ativados, o aumento da capacidade linfoproliferativa e a potencialização da produção de óxido nítrico. 


\section{VII) Referências Bibliográficas}


1. ADAMS, D.O. The structure of mononuclear phagocytes differentiating in vivo. I. Sequential fine and histologic studies of the effect of Bacillus Calmette-Guerin (BCG). Am. J. Pathol., v. 76, p. 17-48, 1974.

2. AGGARWAL, S., GHILARDI, N., XIE, M.H., DE SAUVAGE, F.J., GURNEY, A.L. Interleukin-23 promotes a distinct CD4 T cell activation state characterized by the production of interleukin-17. J. Biol. Chem., v. 278, p. 1910-1914, 2003.

3. AKILOV, O.E., USTYUGOVA, IV, ZHI, L., HASAN, T., WU, M.X. Enhanced susceptibility to Leishmania infection in resistant mice in the absence of immediate early response gene X-1. J. Immunol., v. 183, p. 7994-8003, 2009.

4. AKOPYANTS, N.S., KIMBLIN, N., SECUNDINO, N., PATRICK, R., PETERS, N., LAWYER, P., DOBSON, D.E., BEVERLEY, S.M., SACKS, D.L. Demonstration of genetic exchange during cyclical development of Leishmania in the sand fly vector. Science., v. 324, p. 265-268, 2009.

5. ALEXANDER, J., BRYSON, K. T helper (h)1/Th2 and Leishmania: paradox rather than paradigm. Immunol. Lett., v. 99, p. 17-23, 2005.

6. ALVAR, J., CANAVATE, C., GUTIERREZ-SOLAR, B., JIMENEZ, M., LAGUNA, F., LOPEZ-VELEZ, R., MOLINA, R., MORENO, J. Leishmania and human immunodeficiency virus coinfection: the first 10 years. Clin. Microbiol. Rev., v. 10, p. 298-319, 1997.

7. ANDERSON, C.F., OUKKA, M., KUCHROO, V.J., SACKS, D. CD4(+)CD25()Foxp3(-) Th1 cells are the source of IL-10-mediated immune suppression in chronic cutaneous leishmaniasis. J. Exp. Med., v. 204, p. 285-297, 2007a.

8. ANDERSON, C.F., OUKKA, M., KUCHROO, V.J., SACKS, D. CD4(+)CD25()Foxp3(-) Th1 cells are the source of IL-10-mediated immune suppression in chronic cutaneous leishmaniasis. J. Exp. Med., v. 204, p. 285-297, 2007b.

9. ASHFORD, R.W. The leishmaniases as emerging and reemerging zoonoses. Int. J. Parasitol., v. 30, p. 1269-1281, 2000.

10. ASSEMAN, C., MAUZE, S., LEACH, M.W., COFFMAN, R.L., POWRIE, F. An essential role for interleukin 10 in the function of regulatory $\mathrm{T}$ cells that inhibit intestinal inflammation. J. Exp. Med., v. 190, p. 995-1004, 1999. 
11. AUJLA, S.J., CHAN, Y.R., ZHENG, M., FEI, M., ASKEW, D.J., POCIASK, D.A., REINHART, T.A., MCALLISTER, F., EDEAL, J., GAUS, K., HUSAIN, S., KREINDLER, J.L., DUBIN, P.J., PILEWSKI, J.M., MYERBURG, M.M., MASON, C.A., IWAKURA, Y., KOLLS, J.K. IL-22 mediates mucosal host defense against Gram-negative bacterial pneumonia. Nat. Med., v. 14, p. 275-281, 2008.

12. AWANE, M., ANDRES, P.G., LI, D.J., REINECKER, H.C. NF-kappa B-inducing kinase is a common mediator of IL-17-, TNF-alpha-, and IL-1 betainduced chemokine promoter activation in intestinal epithelial cells. J. Immunol., v. 162, p. 5337-5344, 1999.

13. AWASTHI, A., MATHUR, R.K., SAHA, B. Immune response to Leishmania infection. Indian J. Med. Res., v. 119, p. 238-258, 2004.

14. BABALOO, Z., KAYE, P.M., ESLAMI, M.B. Interleukin-13 in Iranian patients with visceral leishmaniasis: relationship to other Th2 and Th1 cytokines. Trans. R. Soc. Trop. Med. Hyg., v. 95, p. 85-88, 2001.

15. BARRY, S.P., OUNZAIN, S., MCCORMICK, J., SCARABELLI, T.M., CHENSCARABELLI, C., SARAVOLATZ, L.I., FAGGIAN, G., MAZZUCCO, A., SUZUKI, H., THIEMERMANN, C., KNIGHT, R.A., LATCHMAN, D.S., STEPHANOU, A. Enhanced IL-17 signalling following myocardial ischaemia/reperfusion injury. Int. J. Cardiol., v. 2011.

16. BELKAID, Y., HOFFMANN, K.F., MENDEZ, S., KAMHAWI, S., UDEY, M.C., WYNN, T.A., SACKS, D.L. The role of interleukin (IL)-10 in the persistence of Leishmania major in the skin after healing and the therapeutic potential of anti-IL-10 receptor antibody for sterile cure. J. Exp. Med., v. 194, p. 1497-1506, 2001a.

17. BELKAID, Y., HOFFMANN, K.F., MENDEZ, S., KAMHAWI, S., UDEY, M.C., WYNN, T.A., SACKS, D.L. The role of interleukin (IL)-10 in the persistence of Leishmania major in the skin after healing and the therapeutic potential of anti-IL-10 receptor antibody for sterile cure. J. Exp. Med., v. 194, p. 1497-1506, 2001b.

18. BELKAID, Y., PICCIRILLO, C.A., MENDEZ, S., SHEVACH, E.M., SACKS, D.L. $\mathrm{CD} 4+\mathrm{CD} 25+$ regulatory $\mathrm{T}$ cells control Leishmania major persistence and immunity. Nature., v. 420, p. 502-507, 2002a.

19. BELKAID, Y., VON, S.E., MENDEZ, S., LIRA, R., CALER, E., BERTHOLET, S., UDEY, M.C., SACKS, D. CD8+ T cells are required for primary immunity in C57BL/ 6 mice following low-dose, intradermal challenge with Leishmania major. J. Immunol., v. 168, p. 3992-4000, 2002b. 
20. BELOSEVIC, M., FINBLOOM, D.S., VAN DER MEIDE, P.H., SLAYTER, M.V., NACY, C.A. Administration of monoclonal anti-IFN-gamma antibodies in vivo abrogates natural resistance of $\mathrm{C} 3 \mathrm{H} / \mathrm{HeN}$ mice to infection with Leishmania major. J. Immunol., v. 143, p. 266-274, 1989.

21. BETTELLI, E., KORN, T., OUKKA, M., KUCHROO, V.K. Induction and effector functions of T(H)17 cells. Nature., v. 453, p. 1051-1057, 2008.

22. BIRON, C.A., GAZZINELLI, R.T. Effects of IL-12 on immune responses to microbial infections: a key mediator in regulating disease outcome. Curr. Opin. Immunol., v. 7, p. 485-496, 1995.

23. BOGDAN, C., GESSNER, A., SOLBACH, W., ROLLINGHOFF, M. Invasion, control and persistence of Leishmania parasites. Curr. Opin. Immunol., v. 8, p. 517-525, 1996.

24. BOGDAN, C., ROLLINGHOFF, M., DIEFENBACH, A. The role of nitric oxide in innate immunity. Immunol. Rev., v. 173, p. 17-26, 2000.

25. BONIFACE, K., BERNARD, F.X., GARCIA, M., GURNEY, A.L., LECRON, J.C., MOREL, F. IL-22 inhibits epidermal differentiation and induces proinflammatory gene expression and migration of human keratinocytes. J. Immunol., v. 174, p. 3695-3702, 2005.

26. BUFFET, P.A., SULAHIAN, A., GARIN, Y.J., NASSAR, N., DEROUIN, F. Culture microtitration: a sensitive method for quantifying Leishmania infantum in tissues of infected mice. Antimicrob. Agents Chemother., v. 39, p. 2167-2168, 1995.

27. CARREGARO, V., VALENZUELA, J.G., CUNHA, T.M., VERRI, W.A., JR., GRESPAN, R., MATSUMURA, G., RIBEIRO, J.M., ELNAIEM, D.E., SILVA, J.S., CUNHA, F.Q. Phlebotomine salivas inhibit immune inflammation-induced neutrophil migration via an autocrine DCderived PGE2/IL-10 sequential pathway. J. Leukoc. Biol., v. 84, p. 104114, 2008.

28. CARVALHO, E.M., BACELLAR, O., BARRAL, A., BADARO, R., JOHNSON, W.D., JR. Antigen-specific immunosuppression in visceral leishmaniasis is cell mediated. J. Clin. Invest., v. 83, p. 860-864, 1989.

29. CARVALHO, E.M., BACELLAR, O., BROWNELL, C., REGIS, T., COFFMAN, R.L., REED, S.G. Restoration of IFN-gamma production and lymphocyte proliferation in visceral leishmaniasis. J. Immunol., v. 152, p. 5949-5956, 1994. 
30. CARVALHO, E.M., BACELLAR, O.A., REED, S., BARRAL, A., ROCHA, H. Visceral leishmaniasis: a disease associated with inability of lymphocytes to activate macrophages to kill leishmania. Braz. J. Med. Biol. Res., v. 21, p. 85-92, 1988.

31. CARVALHO, E.M., BADARO, R., REED, S.G., JONES, T.C., JOHNSON, W.D., $\mathrm{JR}$. Absence of gamma interferon and interleukin 2 production during active visceral leishmaniasis. J. Clin. Invest., v. 76, p. 2066-2069, 1985.

32. CARVALHO, E.M., BARRAL, A., PEDRAL-SAMPAIO, D., BARRAL-NETTO, M., BADARO, R., ROCHA, H., JOHNSON, W.D., JR. Immunologic markers of clinical evolution in children recently infected with Leishmania donovani chagasi. J. Infect. Dis., v. 165, p. 535-540, 1992.

33. CONTI, H.R., SHEN, F., NAYYAR, N., STOCUM, E., SUN, J.N., LINDEMANN, M.J., HO, A.W., HAI, J.H., YU, J.J., JUNG, J.W., FILLER, S.G., MASSOWELCH, P., EDGERTON, M., GAFFEN, S.L. Th17 cells and IL-17 receptor signaling are essential for mucosal host defense against oral candidiasis. J. Exp. Med., v. 206, p. 299-311, 2009.

34. CUA, D.J., SHERLOCK, J., CHEN, Y., MURPHY, C.A., JOYCE, B., SEYMOUR, B., LUCIAN, L., TO, W., KWAN, S., CHURAKOVA, T., ZURAWSKI, S., WIEKOWSKI, M., LIRA, S.A., GORMAN, D., KASTELEIN, R.A., SEDGWICK, J.D. Interleukin-23 rather than interleukin-12 is the critical cytokine for autoimmune inflammation of the brain. Nature., v. 421, p. 744-748, 2003.

35. CUNHA, F.Q., ASSREUY, J., XU, D., CHARLES, I., LIEW, F.Y., MONCADA, S. Repeated induction of nitric oxide synthase and leishmanicidal activity in murine macrophages. Eur. J. Immunol., v. 23, p. 1385-1388, 1993.

36. DA MATTA GUEDES, P.M., GUTIERREZ, F.R., MAIA, F.L., MILANEZI, C.M., SILVA, G.K., PAVANELLI, W.R., SILVA, J.S. IL-17 produced during Trypanosoma cruzi infection plays a central role in regulating parasiteinduced myocarditis. PLoS. Negl. Trop. Dis., v. 4, p. e604-2010.

37. DESJEUX, P. Leishmaniasis: current situation and new perspectives. Comp Immunol. Microbiol. Infect. Dis., v. 27, p. 305-318, 2004.

38. EL-HASSAN, A.M., MEREDITH, S.E., YAGI, H.I., KHALIL, E.A., GHALIB, H.W., ABBAS, K., ZIJLSTRA, E.E., KROON, C.C., SCHOONE, G.J., ISMAIL, A. Sudanese mucosal leishmaniasis: epidemiology, clinical features, diagnosis, immune responses and treatment. Trans. R. Soc. Trop. Med. Hyg., v. 89, p. 647-652, 1995. 
39. ENGLEN, M.D., VALDEZ, Y.E., LEHNERT, N.M., LEHNERT, B.E. Granulocyte/macrophage colony-stimulating factor is expressed and secreted in cultures of murine L929 cells. J. Immunol. Methods., v. 184, p. 281-283, 1995.

40. ENGWERDA, C.R., KAYE, P.M. Organ-specific immune responses associated with infectious disease. Immunol. Today., v. 21, p. 73-78, 2000.

41. FEHERVARI, Z., SAKAGUCHI, S. CD4+ Tregs and immune control. J. Clin. Invest., v. 114, p. 1209-1217, 2004.

42. FIORENTINO, D.F., BOND, M.W., MOSMANN, T.R. Two types of mouse T helper cell. IV. Th2 clones secrete a factor that inhibits cytokine production by Th1 clones. J. Exp. Med., v. 170, p. 2081-2095, 1989.

43. FRANKE, C.R., ZILLER, M., STAUBACH, C., LATIF, M. Impact of the El Nino/Southern Oscillation on visceral leishmaniasis, Brazil. Emerg. Infect. Dis., v. 8, p. 914-917, 2002.

44. GANTT, K.R., GOLDMAN, T.L., MCCORMICK, M.L., MILLER, M.A., JERONIMO, S.M., NASCIMENTO, E.T., BRITIGAN, B.E., WILSON, M.E. Oxidative responses of human and murine macrophages during phagocytosis of Leishmania chagasi. J. Immunol., v. 167, p. 893-901, 2001.

45. GAUTAM, S., KUMAR, R., MAURYA, R., NYLEN, S., ANSARI, N., RAI, M., SUNDAR, S., SACKS, D. IL-10 neutralization promotes parasite clearance in splenic aspirate cells from patients with visceral leishmaniasis. J. Infect. Dis., v. 204, p. 1134-1137, 2011.

46. GHALIB, H.W., PIUVEZAM, M.R., SKEIKY, Y.A., SIDDIG, M., HASHIM, F.A., EL-HASSAN, A.M., RUSSO, D.M., REED, S.G. Interleukin 10 production correlates with pathology in human Leishmania donovani infections. J. Clin. Invest., v. 92, p. 324-329, 1993.

47. HERWALDT, B.L. Leishmaniasis. Lancet., v. 354, p. 1191-1199, 1999.

48. HUANG, H., KIM, H.J., CHANG, E.J., LEE, Z.H., HWANG, S.J., KIM, H.M., LEE, Y., KIM, H.H. IL-17 stimulates the proliferation and differentiation of human mesenchymal stem cells: implications for bone remodeling. Cell Death. Differ., v. 16, p. 1332-1343, 2009.

49. HUANG, W., LA, R., V, ALZOUBI, A., SCHWARZENBERGER, P. Interleukin17A: a T-cell-derived growth factor for murine and human mesenchymal stem cells. Stem Cells., v. 24, p. 1512-1518, 2006. 
50. HUANG, W., NA, L., FIDEL, P.L., SCHWARZENBERGER, P. Requirement of interleukin-17A for systemic anti-Candida albicans host defense in mice. J. Infect. Dis., v. 190, p. 624-631, 2004.

51. ISHIGAME, H., KAKUTA, S., NAGAI, T., KADOKI, M., NAMBU, A., KOMIYAMA, Y., FUJIKADO, N., TANAHASHI, Y., AKITSU, A., KOTAKI, H., SUDO, K., NAKAE, S., SASAKAWA, C., IWAKURA, Y. Differential roles of interleukin-17A and -17F in host defense against mucoepithelial bacterial infection and allergic responses. Immunity., v. 30, p. 108-119, 2009.

52. JANKOVIC, D., KULLBERG, M.C., FENG, C.G., GOLDSZMID, R.S., COLLAZO, C.M., WILSON, M., WYNN, T.A., KAMANAKA, M., FLAVELL, R.A., SHER, A. Conventional T-bet(+)Foxp3(-) Th1 cells are the major source of host-protective regulatory IL-10 during intracellular protozoan infection. J. Exp. Med., v. 204, p. 273-283, 2007.

53. JERONIMO, S.M., DUGGAL, P., BRAZ, R.F., CHENG, C., MONTEIRO, G.R., NASCIMENTO, E.T., MARTINS, D.R., KARPLUS, T.M., XIMENES, M.F., OLIVEIRA, C.C., PINHEIRO, V.G., PEREIRA, W., PERALTA, J.M., SOUSA, J., MEDEIROS, I.M., PEARSONI, R.D., BURNS, T.L., PUGH, E.W., WILSON, M.E. An emerging peri-urban pattern of infection with Leishmania chagasi, the protozoan causing visceral leishmaniasis in northeast Brazil. Scand. J. Infect. Dis., v. 36, p. 443-449, 2004.

54. KANE, M.M., MOSSER, D.M. The role of IL-10 in promoting disease progression in leishmaniasis. J. Immunol., v. 166, p. 1141-1147, 2001.

55. KAYE, P., SCOTT, P. Leishmaniasis: complexity at the host-pathogen interface. Nat. Rev. Microbiol., v. 9, p. 604-615, 2011.

56. KHADER, S.A., BELL, G.K., PEARL, J.E., FOUNTAIN, J.J., RANGELMORENO, J., CILLEY, G.E., SHEN, F., EATON, S.M., GAFFEN, S.L., SWAIN, S.L., LOCKSLEY, R.M., HAYNES, L., RANDALL, T.D., COOPER, A.M. IL-23 and IL-17 in the establishment of protective pulmonary $\mathrm{CD} 4+\mathrm{T}$ cell responses after vaccination and during Mycobacterium tuberculosis challenge. Nat. Immunol., v. 8, p. 369-377, 2007.

57. KILLICK-KENDRICK, R. Phlebotomine vectors of the leishmaniases: a review. Med. Vet. Entomol., v. 4, p. 1-24, 1990a.

58. KILLICK-KENDRICK, R. The life-cycle of Leishmania in the sandfly with special reference to the form infective to the vertebrate host. Ann. Parasitol. Hum. Comp., v. 65 Suppl 1, p. 37-42, 1990b. 
59. KOLLS, J.K., LINDEN, A. Interleukin-17 family members and inflammation. Immunity., v. 21, p. 467-476, 2004.

60. KOPF, M., BROMBACHER, F., KOHLER, G., KIENZLE, G., WIDMANN, K.H., LEFRANG, K., HUMBORG, C., LEDERMANN, B., SOLBACH, W. IL-4deficient Balb/c mice resist infection with Leishmania major. J. Exp. Med., v. 184, p. 1127-1136, 1996.

61. KREUTZER, R.D., YEMMA, J.J., GROGL, M., TESH, R.B., MARTIN, T.I. Evidence of sexual reproduction in the protozoan parasite Leishmania (Kinetoplastida: Trypanosomatidae). Am. J. Trop. Med. Hyg., v. 51, p. 301-307, 1994.

62. KREYMBORG, K., ETZENSPERGER, R., DUMOUTIER, L., HAAK, S., REBOLLO, A., BUCH, T., HEPPNER, F.L., RENAULD, J.C., BECHER, B. IL-22 is expressed by Th17 cells in an IL-23-dependent fashion, but not required for the development of autoimmune encephalomyelitis. J. Immunol., v. 179, p. 8098-8104, 2007.

63. KRYCZEK, I., BANERJEE, M., CHENG, P., VATAN, L., SZELIGA, W., WEI, S., HUANG, E., FINLAYSON, E., SIMEONE, D., WELLING, T.H., CHANG, A., COUKOS, G., LIU, R., ZOU, W. Phenotype, distribution, generation, and functional and clinical relevance of Th17 cells in the human tumor environments. Blood., v. 114, p. 1141-1149, 2009.

64. KURASAWA, K., HIROSE, K., SANO, H., ENDO, H., SHINKAI, H., NAWATA, Y., TAKABAYASHI, K., IWAMOTO, I. Increased interleukin-17 production in patients with systemic sclerosis. Arthritis Rheum., v. 43, p. 2455-2463, 2000.

65. LAINSON, R., SHAW, J.J., SILVEIRA, F.T. Dermal and visceral leishmaniasis and their causative agents. Trans. R. Soc. Trop. Med. Hyg., v. 81, p. 702$703,1987$.

66. LANGRISH, C.L., CHEN, Y., BLUMENSCHEIN, W.M., MATTSON, J., BASHAM, B., SEDGWICK, J.D., MCCLANAHAN, T., KASTELEIN, R.A., CUA, D.J. IL-23 drives a pathogenic T cell population that induces autoimmune inflammation. J. Exp. Med., v. 201, p. 233-240, 2005.

67. LIEBERMAN, L.A., CARDILLO, F., OWYANG, A.M., RENNICK, D.M., CUA, D.J., KASTELEIN, R.A., HUNTER, C.A. IL-23 provides a limited mechanism of resistance to acute toxoplasmosis in the absence of IL-12. J. Immunol., v. 173, p. 1887-1893, 2004. 
68. LIESE, J., SCHLEICHER, U., BOGDAN, C. The innate immune response against Leishmania parasites. Immunobiology., v. 213, p. 377-387, 2008.

69. LIEW, F.Y., PARKINSON, C., MILLOTT, S., SEVERN, A., CARRIER, M. Tumour necrosis factor (TNF alpha) in leishmaniasis. I. TNF alpha mediates host protection against cutaneous leishmaniasis.

Immunology., v. 69, p. 570-573, 1990.

70. LIEW, F.Y., WEI, X.Q., PROUDFOOT, L. Cytokines and nitric oxide as effector molecules against parasitic infections. Philos. Trans. R. Soc. Lond B Biol. Sci., v. 352, p. 1311-1315, 1997.

71. LIN, Y., RITCHEA, S., LOGAR, A., SLIGHT, S., MESSMER, M., RANGELMORENO, J., GUGLANI, L., ALCORN, J.F., STRAWBRIDGE, H., PARK, S.M., ONISHI, R., NYUGEN, N., WALTER, M.J., POCIASK, D., RANDALL, T.D., GAFFEN, S.L., IWAKURA, Y., KOLLS, J.K., KHADER, S.A. Interleukin-17 is required for T helper 1 cell immunity and host resistance to the intracellular pathogen Francisella tularensis.

Immunity., v. 31, p. 799-810, 2009.

72. LIU, A.C., LEE, M., MCMANUS, B.M., CHOY, J.C. Induction of Endothelial Nitric Oxide Synthase Expression by IL-17 in Human Vascular Endothelial Cells: Implications for Vascular Remodeling in Transplant Vasculopathy. J. Immunol., v. 2012.

73. LOPEZ, K.S., DINGES, S., GRIEWANK, K., IWAKURA, Y., UDEY, M.C., VON, S.E. IL-17 promotes progression of cutaneous leishmaniasis in susceptible mice. J. Immunol., v. 182, p. 3039-3046, 2009.

74. MAURICIO, I.L., STOTHARD, J.R., MILES, M.A. The strange case of Leishmania chagasi. Parasitol. Today., v. 16, p. 188-189, 2000.

75. MCGEACHY, M.J., BAK-JENSEN, K.S., CHEN, Y., TATO, C.M., BLUMENSCHEIN, W., MCCLANAHAN, T., CUA, D.J. TGF-beta and IL- 6 drive the production of IL-17 and IL-10 by T cells and restrain T(H)17 cell-mediated pathology. Nat. Immunol., v. 8, p. 1390-1397, 2007.

76. MCGEACHY, M.J., CUA, D.J. Th17 cell differentiation: the long and winding road. Immunity., v. 28, p. 445-453, 2008.

77. MENDEZ, S., RECKLING, S.K., PICCIRILLO, C.A., SACKS, D., BELKAID, Y. Role for CD4(+) CD25(+) regulatory T cells in reactivation of persistent leishmaniasis and control of concomitant immunity. J. Exp. Med., v. 200, p. 201-210, 2004. 
78. MIOSSEC, P., KORN, T., KUCHROO, V.K. Interleukin-17 and type 17 helper T cells. N. Engl. J. Med., v. 361, p. 888-898, 2009.

79. MIYAZAKI, Y., HAMANO, S., WANG, S., SHIMANOE, Y., IWAKURA, Y., YOSHIDA, H. IL-17 is necessary for host protection against acute-phase Trypanosoma cruzi infection. J. Immunol., v. 185, p. 1150-1157, 2010.

80. MOHRS, M., LEDERMANN, B., KOHLER, G., DORFMULLER, A., GESSNER, A., BROMBACHER, F. Differences between IL-4- and IL-4 receptor alpha-deficient mice in chronic leishmaniasis reveal a protective role for IL-13 receptor signaling. J. Immunol., v. 162, p. 7302-7308, 1999.

81. MOMEN, H., PACHECO, R.S., CUPOLILLO, E., GRIMALDI, J.G. Molecular evidence for the importation of Old World Leishmania into the Americas. Biol. Res., v. 26, p. 249-255, 1993.

82. MOSELEY, T.A., HAUDENSCHILD, D.R., ROSE, L., REDDI, A.H. Interleukin17 family and IL-17 receptors. Cytokine Growth Factor Rev., v. 14, p. 155-174, 2003.

83. MOU, Z., JIA, P., KURIAKOSE, S., KHADEM, F., UZONNA, J.E. Interleukin-17mediated control of parasitemia in experimental Trypanosoma congolense infection in mice. Infect. Immun., v. 78, p. 5271-5279, 2010.

84. MURANSKI, P., BONI, A., ANTONY, P.A., CASSARD, L., IRVINE, K.R., KAISER, A., PAULOS, C.M., PALMER, D.C., TOULOUKIAN, C.E., PTAK, K., GATTINONI, L., WRZESINSKI, C., HINRICHS, C.S., KERSTANN, K.W., FEIGENBAUM, L., CHAN, C.C., RESTIFO, N.P. Tumor-specific Th17-polarized cells eradicate large established melanoma. Blood., v. 112, p. 362-373, 2008.

85. MURPHY, M.L., WILLE, U., VILLEGAS, E.N., HUNTER, C.A., FARRELL, J.P. IL-10 mediates susceptibility to Leishmania donovani infection. Eur. J. Immunol., v. 31, p. 2848-2856, 2001.

86. MURRAY, H.W., LU, C.M., MAUZE, S., FREEMAN, S., MOREIRA, A.L., KAPLAN, G., COFFMAN, R.L. Interleukin-10 (IL-10) in experimental visceral leishmaniasis and IL-10 receptor blockade as immunotherapy. Infect. Immun., v. 70, p. 6284-6293, 2002.

87. MURRAY, H.W., RUBIN, B.Y., ROTHERMEL, C.D. Killing of intracellular Leishmania donovani by lymphokine-stimulated human mononuclear phagocytes. Evidence that interferon-gamma is the activating lymphokine. J. Clin. Invest., v. 72, p. 1506-1510, 1983. 
88. NAGASE, H., JONES, K.M., ANDERSON, C.F., NOBEN-TRAUTH, N. Despite increased CD4+Foxp3+ cells within the infection site, BALB/c IL-4 receptor-deficient mice reveal CD4+Foxp3-negative T cells as a source of IL-10 in Leishmania major susceptibility. J. Immunol., v. 179, p. 2435$2444,2007$.

89. NAKAE, S., NAMBU, A., SUDO, K., IWAKURA, Y. Suppression of immune induction of collagen-induced arthritis in IL-17-deficient mice. J.

Immunol., v. 171, p. 6173-6177, 2003 a.

90. NAKAE, S., SAIJO, S., HORAI, R., SUDO, K., MORI, S., IWAKURA, Y. IL-17 production from activated $\mathrm{T}$ cells is required for the spontaneous development of destructive arthritis in mice deficient in IL-1 receptor antagonist. Proc. Natl. Acad. Sci. U. S. A., v. 100, p. 5986-5990, 2003 b.

91. NEAL, R.A., REEVES, A., PETERS, W. Leishmania infecting man and wild animals in Saudi Arabia. 7. Partial protection of mice against Leishmania major by prior infection with L. arabica. Trans. R. Soc. Trop. Med. Hyg., v. 84, p. 233-238, 1990.

92. NOBEN-TRAUTH, N., LIRA, R., NAGASE, H., PAUL, W.E., SACKS, D.L. The relative contribution of IL-4 receptor signaling and IL-10 to susceptibility to Leishmania major. J. Immunol., v. 170, p. 5152-5158, 2003.

93. NOVOA, R., BACELLAR, O., NASCIMENTO, M., CARDOSO, T.M., RAMASAWMY, R., OLIVEIRA, W.N., SCHRIEFER, A., CARVALHO, E.M. IL-17 and Regulatory Cytokines (IL-10 and IL-27) in L. braziliensis Infection. Parasite Immunol., v. 33, p. 132-136, 2011.

94. NYLEN, S., MAURYA, R., EIDSMO, L., MANANDHAR, K.D., SUNDAR, S., SACKS, D. Splenic accumulation of IL-10 mRNA in T cells distinct from CD4+CD25+ (Foxp3) regulatory T cells in human visceral leishmaniasis. J. Exp. Med., v. 204, p. 805-817, 2007b.

95. NYLEN, S., MAURYA, R., EIDSMO, L., MANANDHAR, K.D., SUNDAR, S., SACKS, D. Splenic accumulation of IL-10 mRNA in T cells distinct from CD4+CD25+ (Foxp3) regulatory T cells in human visceral leishmaniasis. J. Exp. Med., v. 204, p. 805-817, 2007a.

96. OHTANI, H., KATOH, H., TANAKA, T., SAOTOME, M., URUSHIDA, T., SATOH, H., HAYASHI, H. Effects of nitric oxide on mitochondrial permeability transition pore and thiol-mediated responses in cardiac myocytes. Nitric. Oxide., v. 26, p. 95-101, 2011. 
97. OKAMOTO, Y.Y., UMEMURA, M., YAHAGI, A., O'BRIEN, R.L., IKUTA, K., KISHIHARA, K., HARA, H., NAKAE, S., IWAKURA, Y., MATSUZAKI, G. Essential role of IL-17A in the formation of a mycobacterial infectioninduced granuloma in the lung. J. Immunol., v. 184, p. 4414-4422, 2010.

98. OUYANG, W., KOLLS, J.K., ZHENG, Y. The biological functions of T helper 17 cell effector cytokines in inflammation. Immunity., v. 28, p. 454-467, 2008.

99. PADIGEL, U.M., ALEXANDER, J., FARRELL, J.P. The role of interleukin-10 in susceptibility of BALB/c mice to infection with Leishmania mexicana and Leishmania amazonensis. J. Immunol., v. 171, p. 3705-3710, 2003.

100. PAN, H., HONG, F., RADAEVA, S., GAO, B. Hydrodynamic gene delivery of interleukin-22 protects the mouse liver from concanavalin A-, carbon tetrachloride-, and Fas ligand-induced injury via activation of STAT3.

Cell Mol. Immunol., v. 1, p. 43-49, 2004.

101. PARK, H., LI, Z., YANG, X.O., CHANG, S.H., NURIEVA, R., WANG, Y.H., WANG, Y., HOOD, L., ZHU, Z., TIAN, Q., DONG, C. A distinct lineage of $\mathrm{CD} 4 \mathrm{~T}$ cells regulates tissue inflammation by producing interleukin 17. Nat. Immunol., v. 6, p. 1133-1141, 2005.

102. PEARSON, R.D., STEIGBIGEL, R.T. Phagocytosis and killing of the protozoan Leishmania donovani by human polymorphonuclear leukocytes. J. Immunol., v. 127, p. 1438-1443, 1981.

103. PETERS, W., BRYCESON, A., EVANS, D.A., NEAL, R.A., KAYE, P., BLACKWELL, J., KILLICK-KENDRICK, R., LIEW, F.Y. Leishmania infecting man and wild animals in Saudi Arabia. 8. The influence of prior infection with Leishmania arabica on challenge with L. major in man. Trans. R. Soc. Trop. Med. Hyg., v. 84, p. 681-689, 1990.

104. PITTA, M.G., ROMANO, A., CABANTOUS, S., HENRI, S., HAMMAD, A., KOURIBA, B., ARGIRO, L., EL, K.M., BUCHETON, B., MARY, C., ELSAFI, S.H., DESSEIN, A. IL-17 and IL-22 are associated with protection against human kala azar caused by Leishmania donovani. J. Clin. Invest., v. 119, p. 2379-2387, 2009.

105. RADAEVA, S., SUN, R., PAN, H.N., HONG, F., GAO, B. Interleukin 22 (IL-22) plays a protective role in T cell-mediated murine hepatitis: IL-22 is a survival factor for hepatocytes via STAT3 activation. Hepatology., v. 39, p. 1332-1342, 2004. 
106. RAMESH, V. Post-kala-azar dermal leishmaniasis. Australas. J. Dermatol., v. 34, p. 35-1993.

107. REITHINGER, R., DUJARDIN, J.C., LOUZIR, H., PIRMEZ, C., ALEXANDER, B., BROOKER, S. Cutaneous leishmaniasis. Lancet Infect. Dis., v. 7, p. 581-596, 2007.

108. RODRIGUES, O.R., MARQUES, C., SOARES-CLEMENTE, M., FERRONHA, M.H., SANTOS-GOMES, G.M. Identification of regulatory T cells during experimental Leishmania infantum infection. Immunobiology., v. 214, p. 101-111, 2009.

109. ROUGERON, V., DE, M.T., HIDE, M., WALECKX, E., BERMUDEZ, H., AREVALO, J., LLANOS-CUENTAS, A., DUJARDIN, J.C., DE, D.S., LE, R.D., AYALA, F.J., BANULS, A.L. Extreme inbreeding in Leishmania braziliensis. Proc. Natl. Acad. Sci. U. S. A., v. 106, p. 10224-10229, 2009.

110. ROUGERON, V., DE, M.T., KAKO, O.S., HIDE, M., BANULS, A.L. "Everything you always wanted to know about sex (but were afraid to ask)" in Leishmania after two decades of laboratory and field analyses. PLoS. Pathog., v. 6, p. e1001004-2010.

111. RUDNER, X.L., HAPPEL, K.I., YOUNG, E.A., SHELLITO, J.E. Interleukin-23 (IL-23)-IL-17 cytokine axis in murine Pneumocystis carinii infection. Infect. Immun., v. 75, p. 3055-3061, 2007.

112. RUTITZKY, L.I., LOPES, D.R., JR., STADECKER, M.J. Severe CD4 T cellmediated immunopathology in murine schistosomiasis is dependent on IL-12p40 and correlates with high levels of IL-17. J. Immunol., v. 175, p. 3920-3926, 2005.

113. RUTITZKY, L.I., STADECKER, M.J. CD4 T cells producing pro-inflammatory interleukin-17 mediate high pathology in schistosomiasis. Mem. Inst. Oswaldo Cruz., v. 101 Suppl 1, p. 327-330, $2006 a$.

114. RUTITZKY, L.I., STADECKER, M.J. CD4 T cells producing pro-inflammatory interleukin-17 mediate high pathology in schistosomiasis. Mem. Inst. Oswaldo Cruz., v. 101 Suppl 1, p. 327-330, 2006 b.

115. SACKS, D., KAMHAWI, S. Molecular aspects of parasite-vector and vector-host interactions in leishmaniasis. Annu. Rev. Microbiol., v. 55, p. 453-483, 2001. 
116. SACKS, D., NOBEN-TRAUTH, N. The immunology of susceptibility and resistance to Leishmania major in mice. Nat. Rev. Immunol., v. 2, p. 845858, 2002.

117. SACKS, D.L., LAL, S.L., SHRIVASTAVA, S.N., BLACKWELL, J., NEVA, F.A. An analysis of $\mathrm{T}$ cell responsiveness in Indian kala-azar. J. Immunol., v. 138, p. 908-913, 1987.

118. SACKS, D.L., PERKINS, P.V. Development of infective stage Leishmania promastigotes within phlebotomine sand flies. Am. J. Trop. Med. Hyg., v. 34, p. 456-459, 1985.

119. SADICK, M.D., HEINZEL, F.P., HOLADAY, B.J., PU, R.T., DAWKINS, R.S., LOCKSLEY, R.M. Cure of murine leishmaniasis with anti-interleukin 4 monoclonal antibody. Evidence for a T cell-dependent, interferon gamma-independent mechanism. J. Exp. Med., v. 171, p. 115-127, 1990.

120. SAKAGUCHI, S., WING, K., MIYARA, M. Regulatory T cells - a brief history and perspective. Eur. J. Immunol., v. 37 Suppl 1, p. S116-S123, 2007.

121. SCHARTON-KERSTEN, T., AFONSO, L.C., WYSOCKA, M., TRINCHIERI, G., SCOTT, P. IL-12 is required for natural killer cell activation and subsequent $\mathrm{T}$ helper 1 cell development in experimental leishmaniasis. J. Immunol., v. 154, p. 5320-5330, 1995.

122. SCHWANDNER, R., YAMAGUCHI, K., CAO, Z. Requirement of tumor necrosis factor receptor-associated factor (TRAF)6 in interleukin 17 signal transduction. J. Exp. Med., v. 191, p. 1233-1240, 2000.

123. SHAINHEIT, M.G., SMITH, P.M., BAZZONE, L.E., WANG, A.C., RUTITZKY, L.I., STADECKER, M.J. Dendritic cell IL-23 and IL-1 production in response to schistosome eggs induces Th17 cells in a mouse strain prone to severe immunopathology. J. Immunol., v. 181, p. 8559-8567, 2008.

124. SPECTOR, W.G., LYKKE, A.W. The cellular evolution of inflammatory granulomata. J. Pathol. Bacteriol., v. 92, p. 163-167, 1966.

125. STAGER, S., MAROOF, A., ZUBAIRI, S., SANOS, S.L., KOPF, M., KAYE, P.M. Distinct roles for IL-6 and IL-12p40 in mediating protection against Leishmania donovani and the expansion of IL-10+ CD4+ T cells. Eur. J. Immunol., v. 36, p. 1764-1771, 2006.

126. STENGER, S., THURING, H., ROLLINGHOFF, M., BOGDAN, C. Tissue expression of inducible nitric oxide synthase is closely associated with resistance to Leishmania major. J. Exp. Med., v. 180, p. 783-793, 1994. 
127. SYPEK, J.P., CHUNG, C.L., MAYOR, S.E., SUBRAMANYAM, J.M., GOLDMAN, S.J., SIEBURTH, D.S., WOLF, S.F., SCHAUB, R.G. Resolution of cutaneous leishmaniasis: interleukin 12 initiates a protective T helper type 1 immune response. J. Exp. Med., v. 177, p. 1797-1802, 1993.

128. TESH, R.B. Control of zoonotic visceral leishmaniasis: is it time to change strategies? Am. J. Trop. Med. Hyg., v. 52, p. 287-292, 1995.

129. THAKUR, C.P., MITRA, D.K., NARAYAN, S. Skewing of cytokine profiles towards T helper cell type 2 response in visceral leishmaniasis patients unresponsive to sodium antimony gluconate. Trans. R. Soc. Trop. Med. Hyg., v. 97, p. 409-412, 2003.

130. TITUS, R.G., MARCHAND, M., BOON, T., LOUIS, J.A. A limiting dilution assay for quantifying Leishmania major in tissues of infected mice. Parasite Immunol., v. 7, p. 545-555, 1985.

131. UMEMURA, M., YAHAGI, A., HAMADA, S., BEGUM, M.D., WATANABE, H., KAWAKAMI, K., SUDA, T., SUDO, K., NAKAE, S., IWAKURA, Y., MATSUZAKI, G. IL-17-mediated regulation of innate and acquired immune response against pulmonary Mycobacterium bovis bacille Calmette-Guerin infection. J. Immunol., v. 178, p. 3786-3796, 2007.

132. VAN, D., V, GRESNIGT, M.S., KULLBERG, B.J., VAN DER MEER, J.W., JOOSTEN, L.A., NETEA, M.G. Th17 responses and host defense against microorganisms: an overview. BMB. Rep., v. 42, p. 776-787, 2009.

133. VARGAS-INC, XIN, L., SOONG, L. Leishmania braziliensis infection induces dendritic cell activation, ISG15 transcription, and the generation of protective immune responses. J. Immunol., v. 180, p. 7537-7545, 2008.

134. VOLPE, E., SERVANT, N., ZOLLINGER, R., BOGIATZI, S.I., HUPE, P., BARILLOT, E., SOUMELIS, V. A critical function for transforming growth factor-beta, interleukin 23 and proinflammatory cytokines in driving and modulating human $\mathrm{T}(\mathrm{H})-17$ responses. Nat. Immunol., v. 9, p. 650-657, 2008.

135. WEN, X., HE, L., CHI, Y., ZHOU, S., HOELLWARTH, J., ZHANG, C., ZHU, J., WU, C., DHESI, S., WANG, X., LIU, F., SU, C. Dynamics of Th17 cells and their role in Schistosoma japonicum infection in C57BL/ 6 mice.

PLoS. Negl. Trop. Dis., v. 5, p. e1399-2011.

136. WILKE, C.M., WANG, L., WEI, S., KRYCZEK, I., HUANG, E., KAO, J., LIN, Y., FANG, J., ZOU, W. Endogenous interleukin-10 constrains Th17 cells in 
patients with inflammatory bowel disease. J. Transl. Med., v. 9, p. 2172011.

137. WILSON, M.E., JERONIMO, S.M., PEARSON, R.D. Immunopathogenesis of infection with the visceralizing Leishmania species. Microb. Pathog., v. 38, p. 147-160, 2005.

138. WILSON, M.E., SANDOR, M., BLUM, A.M., YOUNG, B.M., METWALI, A., ELLIOTT, D., LYNCH, R.G., WEINSTOCK, J.V. Local suppression of IFN-gamma in hepatic granulomas correlates with tissue-specific replication of Leishmania chagasi. J. Immunol., v. 156, p. 2231-2239, 1996.

139. WILSON, M.E., STREIT, J.A. Visceral leishmaniasis. Gastroenterol. Clin. North Am., v. 25, p. 535-551, 1996.

140. WILSON, N.J., BONIFACE, K., CHAN, J.R., MCKENZIE, B.S., BLUMENSCHEIN, W.M., MATTSON, J.D., BASHAM, B., SMITH, K., CHEN, T., MOREL, F., LECRON, J.C., KASTELEIN, R.A., CUA, D.J., MCCLANAHAN, T.K., BOWMAN, E.P., DE WAAL, M.R.

Development, cytokine profile and function of human interleukin 17producing helper T cells. Nat. Immunol., v. 8, p. 950-957, 2007.

141. WOLK, K., KUNZ, S., WITTE, E., FRIEDRICH, M., ASADULLAH, K., SABAT, R. IL-22 increases the innate immunity of tissues. Immunity., v. 21, p. 241-254, 2004.

142. WOLK, K., WITTE, E., WALLACE, E., DOCKE, W.D., KUNZ, S., ASADULLAH, K., VOLK, H.D., STERRY, W., SABAT, R. IL-22 regulates the expression of genes responsible for antimicrobial defense, cellular differentiation, and mobility in keratinocytes: a potential role in psoriasis. Eur. J. Immunol., v. 36, p. 1309-1323, 2006.

143. WONG, C.K., HO, C.Y., LI, E.K., LAM, C.W. Elevation of proinflammatory cytokine (IL-18, IL-17, IL-12) and Th2 cytokine (IL-4) concentrations in patients with systemic lupus erythematosus. Lupus., v. 9, p. 589-593, 2000.

144. XIMENES, M.F., CASTELLON, E.G., DE SOUZA, M.F., MENEZES, A.A., QUEIROZ, J.W., MACEDO E SILVA VP, JERONIMO, S.M. Effect of abiotic factors on seasonal population dynamics of Lutzomyia longipalpis (Diptera: Psychodidae) in northeastern Brazil. J. Med. Entomol., v. 43, p. 990-995, 2006. 
145. YAMAKAMI, K., AKAO, S., TADAKUMA, T., NITTA, Y., MIYAZAKI, J., YOSHIZAWA, N. Administration of plasmids expressing interleukin-4 and interleukin-10 causes BALB/c mice to induce a T helper 2-type response despite the expected $\mathrm{T}$ helper 1-type response with a low-dose infection of Leishmania major. Immunology., v. 105, p. 515-523, 2002.

146. YANG, Z.S., PENG, Z.H., LI, X.L., SONG, J.W., REN, J.W. [Effect of curcumin on IL-17-induced nitric oxide production and expression of iNOS in human keratinocytes]. Xi. Bao. Yu Fen. Zi. Mian. Yi. Xue. Za Zhi., v. 27, p. 959-961, 2011.

147. YURDAKUL, P. [Immunopathogenesis of Leishmania infections]. Mikrobiyol. Bul., v. 39, p. 363-381, 2005.

148. ZELANTE, T., DE, L.A., BONIFAZI, P., MONTAGNOLI, C., BOZZA, S., MORETTI, S., BELLADONNA, M.L., VACCA, C., CONTE, C., MOSCI, P., BISTONI, F., PUCCETTI, P., KASTELEIN, R.A., KOPF, M., ROMANI, L. IL-23 and the Th17 pathway promote inflammation and impair antifungal immune resistance. Eur. J. Immunol., v. 37, p. 2695-2706, 2007.

149. ZHANG, L., YUAN, S., CHENG, G., GUO, B. Type I IFN promotes IL-10 production from $T$ cells to suppress th17 cells and th17-associated autoimmune inflammation. PLoS. One., v. 6, p. e28432-2011.

150. ZIJLSTRA, E.E., EL-HASSAN, A.M. Leishmaniasis in Sudan. Post kala-azar dermal leishmaniasis. Trans. R. Soc. Trop. Med. Hyg., v. 95 Suppl 1, p. S59-S76, 2001.

151. ZOU, W., RESTIFO, N.P. T(H)17 cells in tumour immunity and immunotherapy. Nat. Rev. Immunol., v. 10, p. 248-256, 2010.

152. MURRAY, H.W. Granulomatous inflammation: host antimicrobial defense in the tissues in visceral leishmaniasis. In GALLIN, J.I., SNYDERMAN, R., editors. Inflammation, Basic Principles and Clinical Correlates. 3rd edition, p.977-94, 1999. 